JOAQUIM TEIXEIRA ALVES

ESPINOSA:

POTÊNCIA NATURAL E SEUS REFLEXOS NO DIREITO E NA POLÍTICA

DISSERTAÇÃO DE MESTRADO

ORIENTADOR: PROFESSOR ASSOCIADO ARI MARCELO SÓLON

UNIVERSIDADE DE SÃO PAULO

FACULDADE DE DIREITO

São Paulo-SP

2015 
JOAQUIM TEIXEIRA ALVES

\title{
ESPINOSA:
}

POTÊNCIA NATURAL E SEUS REFLEXOS NO DIREITO E NA POLÍTICA

\begin{abstract}
Dissertação apresentada à Banca Examinadora do Programa de PósGraduação em Direito, da Faculdade de Direito da Universidade de São Paulo, como exigência parcial para obtenção do título de Mestre em Direito, na área de concentração de Teoria Geral e Filosofia de Direito, sob a orientação do Professor Associado Doutor Ari Marcelo Sólon.
\end{abstract}

UNIVERSIDADE DE SÃO PAULO

FACULDADE DE DIREITO

São Paulo-SP

2015 


\title{
JOAQUIM TEIXEIRA ALVES
}

\section{ESPINOSA: \\ POTÊNCIA NATURAL E SEUS REFLEXOS NO DIREITO E NA POLÍTICA}

\begin{abstract}
Dissertação apresentada à Banca Examinadora do Programa de PósGraduação em Direito, da Faculdade de Direito da Universidade de São Paulo, como exigência parcial para obtenção do título de Mestre em Direito, na área de concentração de Teoria Geral e Filosofia de Direito, sob a orientação do Professor Associado Doutor Ari Marcelo Sólon.
\end{abstract}

São Paulo, de de 2015

BANCA EXAMINADORA

Professor Associado Doutor Ari Marcelo Sólon Orientador 
Este trabalho é dedicado à minha esposa Marisa e meu filho André, pelo apoio que sempre me prodigalizaram e pela renúncia a muitas horas de convívio para poder concluí-lo. 


\section{AGRADECIMENTOS}

À minha família, pelo estímulo que sempre me deu na busca do conhecimento, e pela renúncia a muitos momentos de convívio.

Ao professor Ari Marcelo Sólon, por me ter dado a oportunidade de ser seu orientando, por me orientar neste trabalho, sempre me auxiliando quando necessário com suas ideias e conselhos.

Ao corpo docente da Faculdade de Direito da Universidade de São Paulo, pelo conhecimento transmitido ao longo destes anos, com um agradecimento especial aos professores Alysson Leandro Mascaro e Camilo Onoda Caldas. 
Ocidente a janela em bruma de ouro À luz evoca. Assíduo, o manuscrito Já prenhe de infinito a hora aguarda. Alguém nesta penumbra a Deus constrói, Um homem Deus engendra. É um judeu De tristes olhos e de cítrea pele. O tempo o leva como leva um rio A folha que nas águas vai descendo. Não importa porém; com delicada Geometria insiste o feiticeiro E a Deus cinzela; da doença parte Para a1ém do que nele só é nada. A Deus vai erigindo com palavras. $O$ mais pródigo amor the foi doado, Amor que não espera ser amado."

Jorge Luis Borges 


\section{RESUMO}

ALVES, Joaquim Teixeira. Espinosa: Potência Natural e Seus Reflexos no Direito e na Política. 117 p. Mestrado. Faculdade de Direito, Universidade de São Paulo, São Paulo, 05 mar. 2015.

Este trabalho versa sobre o conceito de potência natural em Espinosa, sua amplitude e abrangência e seus reflexos no direito natural e na política. Procura revelar a originalidade do conceito de direito natural em Espinosa, muito diferente dos pontos de vista de Grotius, de Hobbes e de todos os demais filósofos e doutrinadores, levando-o, também, a uma visão diferente sobre a formação do Estado; e, finalmente, a sua doutrina sobre o Estado e suas diversas instituições políticas, enfatizando sempre a liberdade e a dignidade humanas como a razão de ser da criação desse mesmo Estado. Procuramos também revelar neste modesto trabalho o avanço, a novidade e a contribuição de Espinosa à ciência jurídica contemporânea.

Palavras-chave: Espinosa, Potência Natural, Direito Natural, Estado, Política, Deus ou Natureza, Conatus esse Preservandi, Liberdade, Autopreservação, Alienação. 


\begin{abstract}
ALVES, Joaquim Teixeira. Spinoza: Natural Power and Its Effects on Law and Policy. 117 p. Master. Faculty of Law, University of São Paulo, São Paulo, mar. 052015.

This paper deals with the concept of natural power in Spinoza, its breadth and scope and its effects on natural law and politics. Seeks to reveal the originality of the concept of natural law in Spinoza, very different from the views of Grotius, Hobbes and all other philosophers and scholars, too, leading him to a different view of state formation; and finally, his teaching on the State and its various political institutions, always emphasizing freedom and human dignity as the reason for the creation of that State. We also seek to reveal in this modest work the advance, the novelty and contribution of Spinoza to contemporary legal science.
\end{abstract}

Keywords: Spinoza, Natural Power, Natural Law, State, Politics, God, or Nature, Conatus Esse Preservandi, Freedom, Self-preservation, alienation. 


\section{SUMÁRIO}

INTRODUÇÃO..............................................................................

1. ESPINOSA NO PENSAMENTO MODERNO …........................................ 13

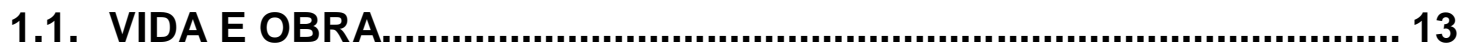

1.2. RAÍZES DO PENSAMENTO DE ESPINOSA .................................... 24

1.3. CONCEPÇÕES DISTINTAS DE DIREITO NATURAL EM ESPINOSA E EM HOBBES ............................................................. 32

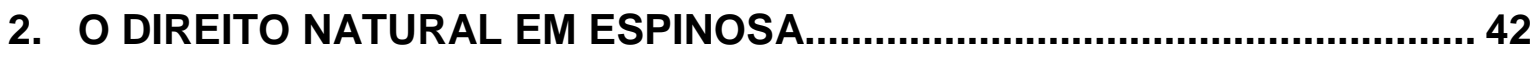

2.1. FUNDAMENTOS METAFÍSICOS DO DIREITO NATURAL................... 42

2.2. CONCEITO DE DIREITO NATURAL .............................................. 48

3. ESTADO E POLÍTICA EM ESPINOSA …….............................................. 55

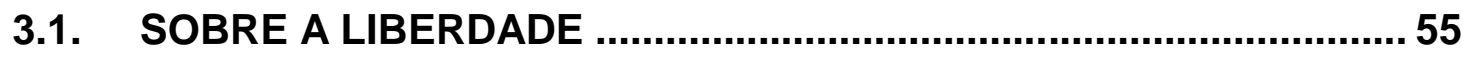

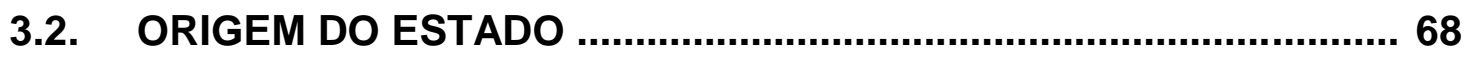

3.3. CRÍTICA Á RELIGIÃO E AO REGIME TEOCRÁTICO....................... 79

3.4. REGIME POLÍTICO IDEAL ......................................................... 91

3.5. O ESTADO E SUAS INSTITUIÇÕES ……....................................... 97

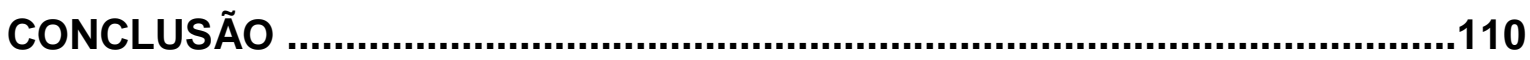

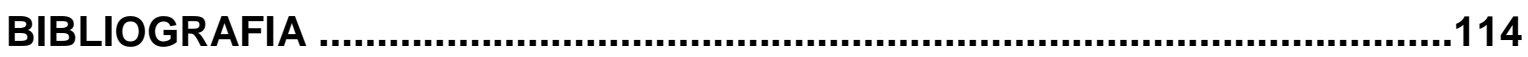




\section{INTRODUÇÃO}

O objetivo desta dissertação é mostrar a contribuição preciosa de Espinosa para o Direito e para a Política, a originalidade e atualidade de suas ideias sobre a matéria, e como essas noções estão interligadas e indissociáveis de suas concepções metafísicas.

Assim, a sua concepção de direito natural é indissociável do conceito de potência natural do indivíduo, e esta noção de potência natural conduz a uma noção muito originalíssima de liberdade. Por sua vez, essa mesma liberdade é constantemente confrontada com a noção do livre arbítrio, negando-o e ultrapassando-o, inserindo-se completamente no campo psicológico e aí, sim, por meio da racionalidade, conquistar o espaço livre da atuação humana. A história da evolução dos regimes políticos, ainda que não linear e contínua, pois sujeita a percalços e retrocessos, é sempre a história pela busca de maior liberdade e melhor desempenho da potência natural (ou seja, direitos).

As noções originalíssimas de direito natural, e sua teoria de formação do Estado, não encontraram um substrato social fértil em seu tempo para vicejarem, já que aos estados absolutistas europeus convinha mais as teorias políticas então em voga, fosse a teoria da origem divina do poder, fosse a teoria da origem contratualista.

A rigor, a sua concepção de direito natural é a antítese lógica e natural das ideias de Grotius sobre a matéria, já que qualquer noção de lógico, de lícito e de justo pressupõe a existência de sociedades organizadas, condicionadas, e o natural é, pela própria definição, alheio a qualquer convenção humana.

Direito natural igual a potência natural, tal é sua fórmula singela para defini-lo. Quanto a uma implantação inata de ideias perenes sobre justiça e licitude, isso é obviamente desmistificado pelo devir histórico do direito, pela multiplicidade de 
formatos tão díspares nos vários estágios civilizacionais e, acima de tudo, pela pertinência do homem às leis físicas da natureza.

As noções de lícito, justo, bom ou mau, são pertinentes a sociedades já estabelecidas, devidamente regradas, e não ao ser humano vivendo em isolamento, confinado em seu habitat natural e só dele dependente. Aqui, neste estágio, seria meu aquilo que eu pudesse pegar, seria lícito ou bom o que conviesse à minha subsistência e autopreservação. llícito ou mau seria o que não me conviesse, ou não me fosse útil. Portanto, estas noções valorativas não são de modo algum direito natural. Este é, pura e simplesmente, a minha total capacidade de agir, de adquirir, de persistir na existência.

Espinosa, como adiante reiterado, encarava como maior bem do homem a sua liberdade ilimitada de pensamento e opinião, já que sua liberdade de agir estaria condicionada, ou às regras sociais, ou às leis da natureza. Aqui, é importante estabelecer uma ponte entre a concepção jurídica e social da liberdade espinosiana com as referências e os fundamentos emprestados de sua metafísica.

Assim, liberdade para Espinosa não é o livre arbítrio humano de possibilidade de escape às leis naturais, às quais todos estamos amarrados, como de resto todas as coisas.

A liberdade, portanto, não é física, é, antes, psíquica. E o será na medida em que o ser humano tome conhecimento de suas limitações físicas, só podendo ultrapassá-las pela consciência dessa necessidade e tendo um pensamento lúcido e livre. Não é por outro motivo que Espinosa sempre enfatiza em seu Tratado Político a necessidade da mais completa liberdade de pensamento e opinião, já que só esta pode ser apanágio do ser humano.

A outra, a liberdade de agir, essa sempre estará condicionada, por um lado, às leis naturais, e, por outro, aos regramentos sociais então vigentes, regras estas idealmente estabelecidas por uma sociedade democrática. Um regime democrático ideal estabeleceria regras sociais de comportamento que não conflitassem com o desenvolvimento do ser humano e sua submissão às leis da natureza. A sua concepção política ideal gira em torno de uma organização da 
sociedade que permita florescer livremente o pensamento criativo do ser humano e a satisfação plena de sua necessidade de autopreservação.

Uma de suas maiores e consequentes intuições políticas é a séria divergência com todos os contratualistas que o antecederam ou sucederam, no tocante à alienação de todos os direitos e autonomia do indivíduo ao Estado, em troca de uma eventual garantia de paz e segurança.

Em maior ou menor grau, todos os contratualistas, a maioria dos pensadores modernos, sustentaram a tese da alienação dos direitos e da autonomia do cidadão ao Estado, o qual então disporia, exclusivamente, de poder e soberania, para ditar as leis que regeriam as sociedades formadas.

Espinosa é a única voz discordante. Para ele, a noção de potência natural, indissoluvelmente ligada à de direito natural, faz que o indivíduo nunca transfira integralmente seu direito natural ao Estado. Pois essa transferência de direito implicaria necessariamente na transferência da potência, e esta é por definição e necessidade intransferível, pois a potência é imprescindível à autopreservação do indivíduo. 


\section{ESPINOSA NO PENSAMENTO MODERNO}

\section{1. VIDA E OBRA}

Em 24 de Novembro de 1632, nasce Baruch (Benedictus) de Espinosa, na cidade de Amsterdam, capital da Holanda, filho de Miguel Espinosa (para outros biógrafos o nome correto seria Manuel), pertencente a uma família de comerciantes judeus de origem portuguesa, radicados numa região nortenha de Portugal contígua à Espanha.

Por séculos, os judeus desfrutaram de paz e convivência pacífica, na Península Ibérica, então sob o domínio dos muçulmanos, os quais sempre concederam tolerância religiosa aos povos que dominavam, uma das marcas da expansão islâmica.

Outra constante da civilização islâmica, então, era a difusão por todas as regiões conquistadas da cultura dos antigos, especialmente a cultura grega, mormente no que concerne a conhecimentos de matemática, geometria, astronomia e filosofia. Muitos teólogos e filósofos judeus abeberaram-se desse caldo cultural, sendo que um dos mais importantes deles, Moses Bem Maimon (Maimônides), teve uma importância decisiva para a fundamentação filosófica do judaísmo e do cristianismo, além de influenciar sobremaneira Espinosa.

Com as guerras ibéricas da Reconquista, e a expulsão dos árabes da Península, mudou radicalmente a vida dos judeus. Antes uma religião tolerada, que podia exercer livremente seu ministério sem ser perturbada pelos muçulmanos, o judaísmo passou a ser perseguido implacavelmente, mormente a partir da instituição dos Tribunais da Inquisição Católica.

Os judeus, então, deixaram de ter liberdade para professar sua religião livre e abertamente, sendo-Ihes oferecidas duas opções: ou se convertiam ao cristianismo, tendo de arcar no caso com uma multa escorchante, ou eram 
forçados ao exílio, com o inevitável confisco de todos os bens que não conseguissem escamotear da sanha confiscatória e arrecadadora do Estado e da Igreja.

Aqueles que resolviam permanecer no solo ibérico eram batizados de cristãosnovos, mas como os europeus sempre procuraram de alguma forma denegrir a origem dos povos refugiados, impingiram a estes o termo pejorativo de marranos.

De acordo com Roger Scruton ${ }^{1}$ :

"julga-se por vezes que o termo marrano deriva da obscura sentença em 1 Coríntios 16,22: 'Se alguém não ama o Senhor, seja anátema! Maranatha'. Poderia ser também uma corruptela de mourisco, ou mouro. Contudo, seu sentido habitual na Espanha é "porco".

Ainda segundo Edgar Morin²:

“Em 1391, na Espanha cristã, um gigantesco 'pogrom' fez 50 mil mortos entre os 300 mil judeus com que contava a península. Cerca de metade dos sobreviventes se converteu e se transformou nos cristãos-novos, ditos conversos ou marranos, enquanto os outros se mantiveram fiéis à Lei de Moisés. O retorno da tolerância dura um século e acaba em 1492, quando Isabel, a Católica, ordena a judeus e a muçulmanos que se convertam ou então que se exilem".

Muitos dos chamados cristãos-novos, ou marranos, continuaram, teimosamente, suas práticas e rituais religiosos, sempre procurando esconder-se dos farejadores da Inquisição, arriscando-se a uma sentença de morte na fogueira, ou, se com sorte, à tortura, sob o olhar complacente dos bispos católicos e com o beneplácito real; outros tantos abafaram silenciosa e amargamente seus credos; e uma minoria conseguiu que certos costumes e certos ritos perdurassem até os dias de hoje, escamoteando a sua origem. É assim que Edgar Morin ${ }^{3}$ nos conta:

“(...) resíduos de práticas (recusa de comer carne de porco, limpar tudo e acender uma vela na sexta-feira, cobrir os espelhos quando morre alguém) persistiram em algumas famílias e, ainda hoje em dia, católicos portugueses e espanhóis, ignorando suas origens, continuam a observar alguns desses usos sem atinar com seu sentido. Algumas ilhas de consciência judaica permaneceram nas regiões de Trás-os-Montes e de Bragança, em Portugal. Foi lá que se descobriu por acaso, em 1925, o vilarejo de Belmonte, onde uma parte da população se dizia judia e uma velha senhora fazia as vezes de rabino, recitando em português o Shema Israel. Em seguida à publicidade feita sobre essa descoberta, certo número de portugueses se reconheceu como de ascendência judaica e alguns se rejudaizaram".

1 SCRUTON, Roger. ESPINOSA. Tradução Luiz Paulo Rouanet. São Paulo: Edições Loyola, São Paulo, 2001, p. 12.

2 MORIN, Edgar. O Mundo Moderno e a Questão Judaica. Tradução Nícia Adan Bonatti. Rio de Janeiro: Bertrand Brasil, 2007, p. 23.

3 lbid., p. 27. 
A família de Espinosa foi uma das muitas famílias que buscaram o exílio, onde pudessem exercer livremente o culto judaico, e não ser forçados a cultuar o catolicismo imposto sem escolhas às consciências. E não havia melhor destino, então, do que as Províncias Unidas dos Países Baixos, a Holanda, que já naquela época, por meio de um decreto da União de Utrecht concedendo liberdade de culto e de opinião, dispensavam uma enorme tolerância e hospitalidade a todos os asilados, ao contrário da maior parte da Europa, envolvida em guerras fraticidas entre católicos e protestantes. E nada melhor que uma grande cidade como Amsterdam, na época um já florescente centro industrial, que se tornou maior ainda com a vinda dos judeus, peritos na arte de lapidação.

Sua família instalou-se num bairro elegante, próximo à velha Sinagoga Portuguesa, lugar que era o reduto dos comerciantes judeus mais abastados de Amsterdam. A mãe de Espinosa, também portuguesa, morreu em trabalhos de parto, quando Espinosa completava seis anos. O pai de Espinosa, Miguel Espinosa, rico comerciante de sucesso, tornou-se um dos principais guardiões da Sinagoga e diretor da escola judaica de Amsterdam. Mas o brilho de sua vida comercial de sucesso foi empanada pela perda de vários familiares, entre os quais três esposas e quatro filhos. Todas estas perdas podem e devem ter se refletido no comportamento um tanto taciturno e reservado de Espinosa.

Espinosa, como de resto todo jovem judeu bem nascido, era obrigado a estudar por várias horas diárias a Bíblia e o Talmude. Nas horas que sobravam, além do estudo do grego e do latim, era obrigado a trabalhar como aprendiz o ofício de polir lentes óticas, pois, segundo um costume judaico, todos os jovens, independentemente da atividade intelectual, tinha de aprender um ofício manual. Como essa atividade de polidor de lentes era a mais recente e uma das mais promissoras, valeu, enfim, para a futura sobrevivência do filósofo, outorgando-lhe uma certa independência, apesar da frugalidade em que vivia, fruto dos parcos rendimentos recebidos com essa profissão.

Aos vinte anos de idade, Espinosa viria a conhecer uma das figuras mais importantes em sua vida, o Professor Van Den Enden, o qual, dono de uma escola famosa pelo pensamento livre em Amsterdam, viria a introduzi-lo, tanto na 
filosofia escolástica, quanto na ciência moderna, e o aproximou de Descartes, insuflando-Ihe um espírito liberal e secular.

Até hoje há uma certa confusão na atribuição correta ao primeiro nome de Espinosa, se Baruch, Bento ou Benedictus, pois os judeus de origem ibérica tinham por costume usar de vários nomes, segundo a conveniência do dia-a-dia, seja no trato comercial, seja no relacional. No trato com a comunidade judaica usavam de preferência o nome judaico, já para operações comerciais preferiam um nome europeu ou latino.

Normalmente, dentro de um caldo tão efervescente de culturas, religiões, práticas e costumes tão díspares, emerge uma cultura liberal e tolerante que faz difundir um certo racionalismo, e este pode tender ao ceticismo, já que toda cultura é apta a oferecer vantagens e desvantagens, e conviver com todas pode disseminar um certo absenteísmo.

$\mathrm{Na}$ Holanda da época conviviam harmoniosamente muitos credos religiosos, e, por absurdo que possa aparecer, só não era permitido, ou era muito pouco tolerado, deixar de acreditar em algum credo: ou seja, o descrente, ou mau seguidor, ou contestador, não era visto com bons olhos pela comunidade a que pertencia e poderia até ser expulso dela.

Pois bem, nesta época de efervescência de culturas e religiões tão diferentes, surgiram vários expoentes contestadores, tais como Montaigne, François Sanchez, Uriel da Costa, Juan de Prado e Espinosa, este, sem dúvida, dono da maior contribuição ao pensamento filosófico moderno.

Embora Espinosa tenha, em sua formação cultural, sofrido a influência de Descartes, divergia profundamente dele quanto à ideia cartesiana da distinta dualidade entre corpo e mente, e, religiosamente, quanto à ideia judaico-cristâ da existência de um Deus criador do universo, exterior a esse mesmo universo criado, e dono de uma Providência divina. Talvez Espinosa, seja por estar imerso num caldo de culturas e religiões tão diferentes, seja por ter sido um leitor insaciável e eclético de pensadores dos mais diversos matizes, seja ainda pelo sofrimento advindo da perda de muitos familiares queridos, não acreditasse no Deus tradicional de seus pais e patrícios, criador do universo, senhor do castigo e 
do perdão, e, contudo, tão indiferente à dor e ao mal que nos atinge diariamente. Deus, para Espinosa, era encarado como a própria Natureza: Deus sive Natura.

Na mesma época em que Espinosa frequentava a Sinagoga, e já começava a ter ideias inadequadas ao ambiente em que se formara e em que vivia, um outro jovem judeu, Uriel da Costa, começou a ter problemas com as autoridades judaicas por suas ideias contestadoras sobre a natureza de Deus, a imortalidade da alma e o destino do homem.

Convidado a retratar-se por várias vezes, por outras tantas voltava a destilar críticas, tanto mais perturbadoras, quanto mais fundamentadas. Na última vez em que foi obrigado a retratar-se e sofreu, por sua recalcitrância, uma punição exemplar de pisoteamento no limiar da Sinagoga, Uriel da Costa foi incapaz de suportar o vexame constrangedor e suicidou-se.

Com seus estudos ecléticos, baseados tanto em autores antigos, como gregos e latinos, quanto em escolásticos, como Maimônides, ou ainda contemporâneos como Descartes, Espinosa começou a erigir um pensamento com luz própria, extremamente liberal e secular, questionando temas muito caros e sagrados do judaísmo e também do cristianismo: a existência de um Deus transcendente e providencial, a imortalidade da alma, a verdade inexpugnável dos textos bíblicos, etc.

Começou, então, o que seria um incômodo ou um embaraço para as autoridades rabínicas com essas ideias provindas de um jovem tão brilhante e promissor, ainda mais oriundo de uma família tão respeitada e tradicional. As autoridades da Sinagoga temiam, além da ofensa à sua própria religião, a repercussão dessas ideias contestadoras junto às autoridades civis dos Países Baixos, já que, apesar de uma relativa tolerância de culto e opinião que estas concediam, o credo oficial continuava a ser o protestantismo, e pior que ter um culto divergente da doutrina oficial, era não ter culto algum.

Espinosa foi então convidado a explicar-se ou retratar-se, negar suas ideias francamente contrárias aos credos judaico e cristão, e também, nesta ocasião, ter-lhe-ia sido oferecida uma pensão anual de 1000 florins se renunciasse às suas ideias, ou, pelo menos, não as divulgasse ou defendesse. Seguindo uma 
independência e honestidade intelectuais que seriam uma de suas marcas por toda a sua vida, Espinosa não só recusou a retratação, como reiterou seu pensamento abertamente contestador, o que fez com que as autoridades rabínicas decidissem pela expulsão do filósofo de sua comunidade e se desse início ao herem, equivalente judaico da excomunhão católica.

Ao som plangente e arrastado de uma enorme trompa, e ao esmorecimento da luz de longos círios negros, um após outro, até a completa escuridão, simbolizando a morte espiritual do membro da comunidade sob julgamento, foi proferida a terrível maldição ritual da excomunhão, "com o anátema pelo qual Josué excomungou Jericó", segundo Roger Scruton ${ }^{4}$ :

"maldito seja ele de dia, e maldito seja de noite; maldito seja quando se deita, e maldito seja quando se levanta; maldito seja quando sai e maldito seja quando retorna, o Senhor não o perdoará; a cólera e a fúria do Senhor se acenderão contra esse homem e trarão sobre ele todas as maldições escritas no Livro da Lei; e o Senhor apagará seu nome debaixo do céu; e, por sua má conduta, o afastará das tribos de Israel, com todas as maldições do firmamento escritas no Livro da Lei; mas os que se mantiverem fiéis ao Senhor Deus vivam todos este dia!

Ordenamos que ninguém se comunique com ele verbalmente ou por escrito, nem lhe faça qualquer favor, nem permaneça sob o mesmo teto que ele, nem permaneça a menos de quatro côvados dele, nem leia qualquer coisa composta ou escrita por ele."

A frieza e crueldade deste anátema podem até ferir nossa sensibilidade contemporânea, e de fato ferem, mas as autoridades da Sinagoga reagiram assim, não apenas como punição às blasfêmias perpetradas contra a sua religião, mas com receio do que as autoridades e o clero protestante, principalmente calvinista, poderia pensar sobre a liberdade permitida pela Sinagoga a um livre pensador, que desrespeitava tanto os credos oficiais e majoritários. $E$ os judeus da Holanda nem sequer detinham, ainda, o status de cidadãos da República, uma vez que continuavam a existir na mera condição de asilados.

Após sua excomunhão e expulsão da comunidade judaica, Espinosa ficou sem um teto judeu a ele familiar sob que abrigar-se e aceitou viver sob os auspícios de seu Professor Van den Enden, lecionando em sua escola, famosa pela difusão de um pensamento liberal e moderno.

Depois, até o final de sua vida que, infelizmente para nós, não foi tão longa, viveria numa tranquila reclusão, morando sempre em singelos quartos. Vivia a

${ }^{4}$ SCRUTON, Roger, op. cit. p. 18. 
expensas de seu trabalho como polidor de lentes, e de uma ou outra modesta pensão concedida por amigos e benfeitores, entre os quais Jan de Witt, estadista que exerceu por algum tempo o cargo de Grande Pensionário dos Países Baixos, uma espécie de Primeiro Ministro de nosso tempo.

O ofício de polir lentes tinha sido aprendido em sua juventude, providência judaica de ministrar sempre aos jovens, independentemente do nível econômico ou intelectual, uma profissão manual. Naquela época começava a haver na Holanda uma grande demanda por lentes, já que eram necessárias para os microscópios usados no comércio de lapidação de diamantes, para os telescópios náuticos e para os óculos de leitura que começavam a ter uma grande difusão, até então inacessíveis a muitos. Segundo Paul Strathern ${ }^{5}$, embora não confirmado por fontes fidedignas, conta-se que havia uma grande procura pelas lentes fabricadas pelo filósofo, não se sabe se pelo seu trabalho como expert, se pela fama que já detinha como filósofo original e contestador. E, ironicamente, o mesmo autor conclui que, de qualquer maneira, o grande pensador não se aproveitou tanto, com certeza, quanto colecionadores contemporâneos titulares de lotes de lentes a ele atribuídas.

E justamente esse ofício de polidor de lentes, apesar de constituir um meio de vida que the rendeu uma certa independência financeira, talvez tenha sido o causador de sua morte precoce por tuberculose, ao ter de inalar diariamente o pó de vidro oriundo do polimento das lentes, juntamente com uma alimentação frugal demais, à base de mingau de leite e pasta de passas, comum naquela época.

Como atrás mencionado, o ofício de polidor de lentes, tão reclamadas no seu tempo, conseguiu dar-lhe uma certa independência financeira, ainda que modesta, independência financeira que foi crucial à sua honestidade e independência intelectuais. Exemplo destas, foi a sua conhecida recusa a uma gorda pensão real em troca de uma dedicatória de um dos seus livros ao todopoderoso Luís XIV da França. Um grande amigo seu, Simon de Vries, quis the deixar todos os seus bens em testamento, mas foi dissuadido pelo próprio

5 STRATHERN, Paul. Spinoza. Tradução Marcus Penchel. Rio de Janeiro: Jorge Zahar Ed., 2000, p. 21. 
Espinosa, que não considerou justo que a família dele ficasse excluída. Aceitou, então, muito a contragosto, uma modesta anuidade de 300 florins.

Numa outra ocasião, recusou a oferta de poder lecionar na Universidade de Heidelberg, feita pelo eleitor palatino, príncipe Karl Ludwig, oferta que, segundo Roger Scruton", Ihe foi transmitida nestes termos: "O senhor terá a mais ampla liberdade de ensino filosófico; o príncipe tem certeza de que ela não será mal utilizada para perturbar a religião publicamente estabelecida". Espinosa recusou com extrema polidez e elegância, afirmando que não poderia concordar com tais cláusulas, as quais impunham limites indeterminados à sua liberdade intelectual.

Em seu retiro voluntário, escreveu Espinosa a quase totalidade de suas obras, e, particularmente, duas delas se destacam e projetaram Espinosa no mundo da filosofia de seu tempo e muito para além dele, enquanto a memória humana perdurar. Um deles, o Tratado Teológico-Político, que já defendia a soberania da lei escrita e referendada, a mais completa liberdade de culto e opinião, a manutenção de um governo exclusivamente secular e a existência de um Deus impessoal e imanente, foi publicado ainda em vida do filósofo, mas, apesar de publicado anonimamente, muito rapidamente foi difundida a sua autoria. O livro ficou proibido por longos anos, e chegou a ficar inscrito no "Index Purgatoris", uma relação de livros proibidos pela Igreja, com força de lei, como contrários à religião e à moral. Essa publicação rendeu-Ihe várias homenagens, tais como "o livro foi forjado no inferno por um judeu renegado juntamente com o diabo". ${ }^{7}$

O segundo livro importante que projetaria Espinosa para todo o sempre, sua obraprima, e the reservou um lugar de proeminência no mundo da filosofia e do pensamento universais, foi sua Ética, escrita em latim, num estilo batizado de geométrico, o qual acabou comprometendo muito sua leitura e interpretação. Esse estilo dito geométrico fica patente na exposição de suas ideias, numa espécie de geometria euclidiana, com definições, axiomas, proposições e demonstrações. Essa configuração torna o livro de difícil leitura, só acessível aos leitores mais eruditos.

\footnotetext{
${ }^{6}$ SCRUTON, Roger, op. cit. p. 23.
}

7 Ibid., p. 42. 
Ainda que Espinosa não tenha feito publicar o livro em vida, com receio da polêmica e hostilidade que ele poderia provocar, como de fato provocou, o livro circulou em manuscrito e já atraiu muita atenção por parte de alguns eruditos que a ele tiveram acesso.

Um dos privilegiados que mais cedo tiveram acesso ao manuscrito foi Leibniz, apesar de relações estremecidas entre ambos, já que nutriam uma desconfiança recíproca. De acordo com Roger Scruton ${ }^{8}$, Leibniz referia-se privadamente a ele "como um judeu expulso da Sinagoga por suas opiniões monstruosas". Paul Strathern ${ }^{9}$ dá o troco, afirmando que, muito provavelmente, já que os pressupostos fundamentais dos sistemas dos dois filósofos são estranhamente parecidos, há quem impute a Leibniz um parcial plágio da Ética espinosiana.

Segundo Roger Scruton ${ }^{10}$, as razões de Espinosa para não publicar a sua obraprima em vida, estão expostas em sua carta LXVIII ao seu amigo Oldenburg:

"Eu partira para Amsterdam com o propósito de publicar o livro que mencionei a você.
Enquanto eu negociava isso, cresceu um boato de que eu tinha no prelo um livro
concernente a Deus, no qual eu procurava mostrar que não existe Deus. Certos
teólogos, então, talvez os autores do boato, aproveitaram a oportunidade para
queixar-se de mim diante do príncipe e dos magistrados; além disso, os estúpidos
cartesianos, sendo suspeitos de me beneficiar, tentaram afastar as calúnias atacando
em todo o lugar minhas opiniões e meus escritos, um comportamento que eles ainda
mantêm. Quando soube disso por meio de pessoas de confiança, que também me
garantiram que os teólogos estavam à minha espreita em toda a parte, decidi
suspender a publicação até saber o rumo que as coisas tomavam". Nesse livro Espinosa identifica Deus com o Universo, Deus sive Natura. E o Universo é construído como um sistema absolutamente necessário, previsível, determinístico, baseado em leis que são eternas e imutáveis. Já a moral é construída com base no critério da utilidade, uma vez que todo o ser busca a sua autopreservação, e não importa a que preço.

Não há também lugar para a distinção cartesiana entre res cogitans e res extensa, entre mente e corpo, já que os dois não passam de atributos diferentes da mesma substância, ou seja, pensamento e extensão. Com isso, superou o problema cartesiano da justificação da interação entre corpo e mente.

\footnotetext{
${ }^{8}$ SCRUTON, Roger, op. cit. p. 24.

${ }^{9}$ STRATHERN, Paul, op. cit. p. 45.

${ }^{10}$ SCRUTON, Roger, op. cit. p. 24.
} 
Sua hipótese de Deus identifica-se plena e cabalmente com o Universo, ou com a Natureza como ele queria, com seu cortejo e sequência de leis absolutas e necessárias, e, acima de tudo, não voluntariosas, se aproximando muito das modernas teorias científicas unificadas.

Como diz Paul Strathern ${ }^{11}$, até o próprio Stephen Hawking foi levado a indagar: "Será a teoria unificada tão forte que implique sua própria existência?" De onde se concluiria, seguindo rigorosamente o pensamento espinosiano, que o Universo deve ser exatamente como é, nem mais nem menos, e nenhum outro (ou nada) seria então possível.

O próprio Espinosa traçou o seu projeto de vida em seu livro Tratado da Reforma do Entendimento:

"Depois que a experiência me ensinou que tudo o que ocorre com frequência na vida é vão e fútil; quando vi que tudo o que eu temia não tinha em si nada de bom nem de mau, a não ser à medida que meu espírito se agitava com isso, decidi finalmente inquirir se haveria algo que fosse um verdadeiro bem, suscetível de se comunicar e pelo qual somente, rejeitando todas as outras coisas, o ânimo fosse afetado; mais ainda, se haveria algo que, uma vez encontrado e adquirido, me permitisse usufruir de uma alegria contínua e suprema por toda a eternidade. (...) De fato, o que mais frequentemente ocorre na vida e o que os homens, pelo que se pode deduzir de suas ações, estimam como bem supremo, se resume a estas três coisas: riquezas, honra e prazer sensual. Por estas três coisas o espírito é de tal modo distraído, que mal pode pensar em outro bem. (...) Todas essas coisas, porém, que o comum dos homens procura, não somente não fornecem nenhum remédio para conservar nosso ser, mas até o impedem, e frequentemente são causa de ruína para aqueles que por elas são possuídos. (...) Além disso, esses males pareciam provir do fato de que toda a felicidade ou infelicidade depende de uma só coisa, ou seja, da qualidade do objeto ao qual nos apegamos com amor. De fato, nunca haverá de surgir discórdia por aquilo que não se ama, nenhuma tristeza se for perdido, nenhuma inveja se for possuído por outro, nenhum temor, nenhum ódio e, para dizê-lo numa palavra, nenhuma comoção de espírito; tudo isso, ao contrário, acontece por causa do amor que nutrimos pelas coisas perecíveis, como o são todas aquelas de que acabamos de falar. Mas o amor de uma coisa eterna e infinita alimenta a alma de pura alegria, isenta de toda tristeza, o que deve ser profundamente desejado e procurado com todas as forças. (...) Direi aqui brevemente o que entendo por verdadeiro bem e ao mesmo tempo o que é o sumo bem: é certamente o conhecimento da união que a mente possui com toda a natureza"12

Apesar deste belíssimo projeto de existência, que Espinosa tentou seguir à risca em sua curta, mas profícua vida, ainda assim, houve quem o definisse como a

\footnotetext{
11 STRATHERN, Paul, op. cit. p. 29.

12 ESPINOSA. Tratado da Reforma do Entendimento. São Paulo: Escala editora, p. $19-21$ - 23 27.
} 
"hipótese mais monstruosa", segundo a definição de Bayle em seu Dictionnaire, e o próprio Hume classificou sua obra como "hipótese absurda". ${ }^{13}$

O espinosismo nasceu exatamente como reação a esta perseguição injusta e implacável a um homem que sempre pôs a liberdade de pensamento e opinião acima de tudo, e buscou no amor a solução para todos os problemas, apesar da busca do útil por todo o ser existente em busca da sua autopreservação.

Como diz Antonio Negri ${ }^{14}$, "Ser spinozistas no es uma determinación - por el contrario, es uma condición - para pensar es preciso ser spinozistas". 


\section{2. RAÍZES DO PENSAMENTO DE ESPINOSA}

O exílio forçado a que a família de Espinosa se submeteu, ao buscar refugio nas Províncias Unidas dos Países Baixos, Holanda, fugindo à implacável perseguição na Península Ibérica, por conta da malfadada Santa Inquisição, trouxe um grande benefício para a humanidade: de fato, só numa terra liberal, com relativa tolerância de culto e opinião, poderia ter florescido o pensamento contestador e revolucionário de Espinosa. Seria impensável que isso pudesse acontecer em terras ibéricas, onde dominava o total obscurantismo, pela perniciosa influência exercida pela Igreja católica, por intermédio de seu braço secular, a Santa Inquisição, a qual se impunha mesmo aos governos constituídos.

À tolerância islâmica anterior, seguir-se-ia todo um séquito interminável de perseguições, que iria gerar uma paralisia intelectual por longos séculos, tendo como fonte ideias arraigadas e anacrônicas, baseadas numa visão retrógrada dos meios e fins que devem presidir à celebração e eleição de um credo religioso. Enquanto nos países protestantes, por meio da Reforma e de uma guinada nos fins almejados pela religião, procurava difundir-se a ciência e a livre filosofia, a Península Ibérica iria amargurar por vários séculos, até recentes dias, uma carência total dos ideais da ciência, da filosofia, do livre pensamento e, por consequência, da liberdade.

Ao contrário de Giordano Bruno, que, por suas ideias contestadoras, foi imolado na fogueira do Santo Ofício, Espinosa pode desenvolver suas ideias plenamente, ainda que tenha sido excomungado e expulso de sua comunidade judaica. Mas até essas excomunhão e expulsão foram benéficas para ele e para toda a humanidade, já que trouxeram como resultado a confecção de uma das mais importantes obras filosóficas, a Ética, e um trabalho extremamente contestador e original, o Tratado Teológico-Político, seguido por outro trabalho igualmente memorável, o Tratado Político, infelizmente inacabado por sua morte prematura.

Devido à condição econômica que desfrutava, em virtude de sua família ser influente e detentora de muitos bens, pode Espinosa ter amplo acesso a todos os 
livros então disponíveis, desde os clássicos gregos e latinos até os mais contemporâneos, como as obras de Grotius, Hobbes e Descartes.

Nos autores gregos, pré-socráticos, estóicos, atomistas, encontrou Espinosa uma certa identidade de pensamento, mormente em relação a seu panteísmo, embora original, à sua ideia da não criação do mundo, ao conceito materialista atomista, à resignação dos estóicos, e até à busca do útil como substituição do prazer nos epicuristas.

Assim, algumas máximas de Demócrito encontram eco no pensamento de Espinosa, e constituem um sólido fundamento em que assenta uma parte da sua Ética.

Pois bem, vejamos em que consistia o critério hedonista para Demócrito: "Prazer e dor constituem o critério do útil e do prejudicial". ${ }^{15}$

Sobre a matéria, assim discorre Espinosa: "Por bom, entendo aquilo que certamente sabemos ser-nos útil. Por mal, ao contrário, aquilo que sabemos com certeza que nos impede de nos tornarmos senhores de um bem qualquer". ${ }^{16}$

Para Demócrito, o prazer espiritual e a felicidade consistiam em:

\begin{abstract}
"A felicidade e a infelicidade da alma não residem na posse de gado ou de ouro (...)Para os homens, a felicidade nasce da medida e da proporção da vida; toda falta ou excesso acarreta mudanças para pior e gera grandes movimentos na alma (...) Belo é o justo em cada coisa; o excesso e a falta não me parecem, entretanto, que o sejam"17.
\end{abstract}

Também, para Espinosa:

\begin{abstract}
"A alegria e a tristeza são paixões pelas quais a capacidade de cada indivíduo, ou o seu esforço para perseverar no seu ser, é aumentada ou diminuída, favorecida ou reduzida. A alegria (Laetitia) é a passagem do homem de uma perfeição menor para uma maior. A tristeza (Tristitia) é a passagem do homem de uma perfeição maior para uma menor. A luxúria é o desejo ou até o amor imoderado dos prazeres da mesa. A embriaguez é o desejo e o amor imoderado da bebida. A avareza é o desejo e o amor imoderado das riquezas". ${ }^{18}$
\end{abstract}

A perfeição a que se refere Espinosa é a adequação de nossos atos à razão, de apenas buscarmos a satisfação de prazeres que sejam verdadeiramente úteis à

${ }^{15}$ MONDOLFO, Rodolfo. O PENSAMENTO ANTIGO. Tradução de Lycurgo Gomes da Motta. São Paulo: Editora Mestre Jou, 1971, p. 130).

${ }^{16}$ ESPINOSA. ÉTICA. São Paulo: Abril S.A. Cultural, 1973, p. 235.

${ }_{17}$ MONDOLFO, Rodolfo, op. cit. p.130.

${ }^{18}$ ESPINOSA, op. cit. p. 218. 
nossa preservação. A dor, como desejo não satisfeito, deriva de um cálculo irracional da nossa parte, uma vez que não é natural buscar-se coisas inacessíveis, já que se forem inacessíveis não parecerão naturais à nossa razão. A tônica é colocada, então, na moderação doa apetites, pois seu excesso pode trazer-nos, tanto a dor da carência como a inacessibilidade do objeto externo.

A ênfase em Demócrito sobre o domínio das paixões estava na sabedoria e na virtude. Assim, ele já antecipa Sócrates:

"É árduo combater contra o próprio coração; mas vencê-lo é próprio do homem que raciocina bem. Vencer-se a si mesmo é a primeira de todas as vitórias; ser vencido por si mesmo é a mais torpe e a pior cousa. Não somente é heroico o vencedor de inimigos, mas também o triunfador dos seus próprios desejos. A ignorância do melhor é causa do pecado. A medicina cura os males do corpo; a Sabedoria liberta a alma das paixões". ${ }^{19}$

Também Sócrates sempre pregou e agiu nesse mesmo sentido. Pois bem, de acordo com Mondolfo, baseado na Ética a Nicômaco de Aristóteles:

\begin{abstract}
"A identidade da Ciência e da virtude, afirmada por Sócrates, exige, para ser compreendida, que se recorde a função atribuída à Ciência pelo pitagorismo, que a considerava caminho de purificação espiritual e de libertação do pecado. Esta ideia, que Platão torna a afirmar no Mémnon, no Fedro, não deve ter permanecido estranha a Sócrates, como parece pelo valor religioso que ele atribui à função do filósofo e pela função de purgação espiritual que atribui à refutação do erro. A sua ética, pois, já não pode considerar-se mais exclusivamente intelectualista, porque 0 aparente intelectualismo está inspirado em um misticismo profundo".20
\end{abstract}

Da mesma forma, para Espinosa a virtude estaria no conhecimento e a ignorância seria a única causa do mal:

"O homem enquanto é determinado a fazer alguma coisa pelo fato de ter ideias inadequadas, não se pode dizer absolutamente que age por virtude; mas, sim, somente enquanto é determinado pelo fato de ter um conhecimento adequado. Agir absolutamente por virtude não é, em nós, outra coisa que agir, viver, conservar o seu ser (...) sob a direção da razão, segundo o princípio da procura da própria utilidade". ${ }^{21}$

Já quanto à noção de dever, há uma certa divergência entre o pensamento de Demócrito e o de Espinosa. Com efeito, para Demócrito, o dever era considerado como um bem em si mesmo: "É necessário abster-se do pecado, não por medo, mas por dever. Não é benéfico quem espera remuneração, mas quem preferiu fazer o bem";22

\footnotetext{
${ }^{19}$ MONDOLFO, Rodolfo, op. cit. p. 130.

20 lbid., p. 170.

${ }^{21}$ ESPINOSA, Ética, op. cit. p. 247.

22 MONDOLFO, Rodolfo, op. cit. p. 130.
} 
Ora, sabemos que em Espinosa o móbil da nossa razão é a ação em prol da autopreservação. E essa ação sempre deve buscar aquilo que for útil para esse fim, e, por outro lado, procurar afastar-nos daquilo que parecer prejudicial. Assim, não existiria a ideia de dever a ser satisfeita, nem tampouco a ideia de pecado a ser afastada. O pecado não existe na natureza, como também não existe qualquer finalidade ôntica inscrita em nossas consciências. Só a noção da utilidade nos move.

Outras influências importantes no pensamento espinosiano vêm do estoicismo grego, e de seus seguidores em Roma como Cícero, Sêneca e Marco Aurélio. Para os estóicos, o mundo é panteísta, e Deus seria a alma das coisas, imprimindo ao mundo uma lei de rigorosa necessidade. Tudo seria rigorosamente determinado, e a felicidade estaria na resignação do ser humano a esse fatalismo perturbador.

Séculos mais tarde, Espinosa, ainda que seguindo este mesmo raciocínio da presença de Deus no mundo, e com este se identificando, introduz uma mudança nesse pensamento que, ainda que sutil, afasta esse fatalismo. Ainda que as leis físicas da natureza sejam necessárias, ainda que exista uma determinação evidente, não há contudo um fatalismo cego: os efeitos só acontecem se as causas atuarem, não necessariamente acontecerão sem a presença das causas. $\mathrm{E}$, quanto ao homem, não é correto afirmar-se que só lhe resta resignar-se perante o destino: o ser humano tem uma ferramenta chamada razão que o deve conduzir ao caminho da autopreservação, buscando o que Ihe for útil, e rejeitando o que for prejudicial. Então, a razão atuaria contra o fatalismo cego dos estóicos.

O que confere uma certa identidade entre o pensamento estóico e o espinosiano é a doutrina de uma vida regida o máximo possível pelos cânones da natureza. Mas Espinosa procura enfatizar que a natureza no ser humano é também racional, e a razão sempre procura iluminar os passos do homem rumo à sua plena realização. Ela sempre deve triunfar sobre as paixões e sobre a imaginação que sempre estão presentes no homem, já que este é constituído por razão e sensibilidade. $\mathrm{E}$ a sensibilidade nem sempre comunga dos ideais da razão: antes, com frequência, uma exclui e afasta a outra. 
A ideia do determinismo estóico é, contudo, seguida muito de perto por Espinosa, para quem a ideia de liberdade absoluta é derivada da ignorância das verdadeiras causas que regem a natureza. O ser humano, em maior ou menor grau, dependendo da maior ou menor sabedoria de cada um, ignora, no fundo, por que age desta ou daquela maneira. Pelo fato de ter consciência de suas ações, imagina-se sempre no comando delas:

\begin{abstract}
"Os homens enganam-se quando se julgam livres, e esta opinião consiste apenas em que eles têm consciência das suas ações e são ignorantes das causas pelas quais são determinados. O que constitui, portanto, a ideia da sua liberdade é que eles não conhecem nenhuma causa das suas ações. Com efeito, quando dizem que as ações humanas dependem da vontade, dizem meras palavras das quais não têm a mínima ideia"23.
\end{abstract}

Os primeiros autores a que Espinosa teve acesso, como não poderia deixar de ser, foram pensadores judeus do século XVII e seguintes, tais como Moisés Maimônides, Levi Bem Gerson, Ibn Ezra, Chasdai Creskas e Leão Hebreu.

Moisés Maimônides escreveu, entre outros livros, o "Guia dos Perplexos", no qual procura conciliar a racionalidade aristotélica com a religião, a lei mosaica e todo o conteúdo bíblico. Todo o esforço de Maimônides foi no sentido de conciliar razão e religião, aparar as contradições entre elas, o que Espinosa combateria em seu Tratado Teológico Político. Por intermédio de Maimônides, ele chegou à doutrina de Averróis, o qual já pregava que, se houvesse imortalidade, e esta seria só a da razão, ela seria necessariamente impessoal.

Com a Cabala (um extenso repertório esotérico sobre interpretação bíblica, comentários sobre o Universo, a natureza do pecado, etc.) ele chegou à identificação de Deus com o Universo. Bem Gerson também comungava desse pensamento e advogava a eternidade do mundo. Também Creskas de Saragoça considerava a eternidade da matéria e a Criação nada seria além de uma imposição de determinada ordem à matéria existente. Como veremos neste trabalho, todas essas influências perduraram e floresceram no pensamento espinosiano.

Mas um dos alicerces da sua obra, que depois modificaria radicalmente, foi a filosofia de Aristóteles, plataforma obrigatória para qualquer filósofo saído da era medieval: assim, a ideia de substância como algo que permanece para além dos

${ }^{23}$ ESPINOSA. ÉTICA, op. cit. p. 166. 
seus atributos ou predicados; a ideia da essência como a razão de ser da substância; a prova ontológica da existência de Deus, como um ser necessário dotado de onipotência e onisciência, e que Avicena desenvolveria posteriormente; e uma influência, ainda que embrionária, da Ética a Nicômaco, com sua ênfase na razão humana, buscando a felicidade, mediante o controle das emoções e uso do bom senso.

Um outro filósofo, mais contemporâneo, que comungava de ideias muito próximas de Espinosa, e que talvez o tenha influenciado de algum modo, foi Giordano Bruno. Grande pensador livre, espírito irrequieto e original, o qual, por suas ideias sobre a identificação de Deus com o Universo, e a identidade entre espírito e matéria, foi perseguido e imolado na fogueira pela Santa Inquisição. Giordano Bruno, ao contrário de outro pensador precursor da modernidade, Galileu Galilei, ao ser questionado sobre a autenticidade de suas ideias e ao ser convidado a retratar-se, não se dobrou a seus algozes obscurantistas e reafirmou as suas convicções. Há até quem diga que, mesmo no momento de ser imolado na fogueira do ódio e do obscurantismo, ele teria gritado a plenos pulmões, antes de completamente sufocados pela fumaça, a respeito da mobilidade da terra em volta do sol: mas que ela se move, se move.

No entanto, decisivas e mais próximas para a conclusão da obra espinosiana, foram as contribuições de Descartes, e de Grotius e de Hobbes para o desenvolvimento de sua filosofia política. Espinosa foi, seguramente, um dos maiores filósofos racionalistas, e herdou comprovadamente de Descartes seu método científico de procurar chegar à verdade através de uma dúvida metódica. Dúvida essa que consistia em aceitar, inicialmente, por verdades apenas aquelas reveladas por absoluta evidência, e a partir daí, por um método analítico de deduções seguras, matemáticas, construir um sólido edifício da ciência com bases puramente racionais e não empiristas.

Ao contrário de Bacon e da filosofia insular inglesa que o seguiu, para quem o verdadeiro conhecimento teria de ser obtido exclusivamente da experiência, através da apreensão das sensações fornecidas por nossos sentidos, e não pela razão que pode frequentemente enganar-nos, com a criação de ilusões e o excesso da imaginação, em Descartes o verdadeiro conhecimento deve ter por 
origem unicamente a razão. Não podemos servir-nos dos sentidos para apreender a essência das coisas, já que esta não se revela aos nossos sentidos. Com os sentidos só nos é dado apreender manifestações da matéria que nada nos dizem sobre verdadeira natureza das coisas. Só a evidência racional, conduzida por uma dúvida voluntária e prudente, poderia nos conduzir à verdade.

Espinosa seguiria rigorosamente o critério racionalista de seu mestre mais próximo, aplicando até um rigor analítico próximo da geometria em sua obraprima, a Ética, com seus axiomas, definições, corolários, etc.

Mas, como na história daquele discípulo que procura ultrapassar o mestre, ou do súdito que busca ser mais realista que o próprio rei, Espinosa conseguiu ser mais racional que Descartes, ao aplicar à própria natureza das emoções humanas o método analítico racional, e chegou a conclusões muito distintas das cartesianas.

A principal delas talvez tenha sido o seu monismo panteísta, oposto à dualidade de espírito e matéria. Enquanto para Descartes existiriam duas realidades distintas, a res cogitans e a res extensa, e daí a sua insanável dificuldade de mostrar como as duas se comunicavam e se influenciavam, para Espinosa matéria e pensamento não passavam de dois atributos da mesma substância, resolvendo assim o problema da influência recíproca entre corpo e mente. Além disso, Deus seria de uma imanência absoluta, e de uma absoluta necessidade, e a imortalidade totalmente impessoal e diluída na substância eterna divina.

No tocante ao jusnaturalista Grotius e ao contratualista Hobbes, Espinosa colheu dos dois pensadores alguns subsídios para a elaboração de seus dois Tratados Políticos, tratados esses recheados de noções atualíssimas sobre política, liberdade, democracia e direitos humanos. Grotius pode ser considerado como o fundador do direito natural das nações, direito esse implantado em todas as mentes humanas por uma razão eterna, oriunda de Deus, e que seria o fundamento de todas as soberanias. Esse direito seria eterno, imutável, e legitimaria o governo absoluto dentro das fronteiras de cada país. A função do sistema estatal legal é fazer cumprir o direito natural racional.

Quanto a Hobbes, ele também perfilhava a ideia de um direito natural, mas não imposto pela razão, e esse direito natural seria totalmente inócuo sem o 
resguardo de um Estado forte que o fizesse valer para todos, legitimando assim o uso da força pelo soberano. Já para Espinosa, embora aceitasse enfaticamente a ideia de um direito natural, divergia de Grotius no tocante ao próprio conceito de direito natural, e divergia ainda mais dos dois doutrinadores quanto a um ponto essencial do hipotético contratualismo, o qual será desenvolvido ao longo deste trabalho: a alienação dos direitos individuais ao Estado, ainda que num contexto de contrato social como pretendia Hobbes, não poderia ser nunca absoluta e total. Dentro da pessoa humana restaria sempre intocável um núcleo de direitos inalienáveis: "ninguém pode jamais transferir tão radicalmente seu poder a outro, e, por consequente, seus direitos, a ponto de deixar de ser um homem"24

${ }^{24}$ ESPINOSA. Tratado Teológico-Político, XVII, apud Roger Scruton, op. cit. p. 109. 


\section{3. CONCEPÇÕES DISTINTAS DE DIREITO NATURAL EM ESPINOSA E EM HOBBES}

Espinosa só considerava possível a existência de um direito natural no estado natural, sendo este considerado como aquela situação em que o ser humano não estava dependente nem subordinado a leis ou a instituições criadas artificialmente. Leis ou regramentos que existissem, seriam só os da natureza.

Já Hobbes, segundo Yara Frateschi ${ }^{25}$, definia o direito da natureza como:

"a liberdade que os homens possuem de fazer tudo o que julgarem necessário para a
preservação da própria vida. Note-se que o direito da natureza é um fato da natureza:
é tendência humana natural persistir na vida, e os homens agem naturalmente para
preservá-la e para evitar a morte". Como diz Alysson Leandro Mascaro ${ }^{26}$, o direito natural hobbesiano não pode ser considerado assente em valores altruísticos, mas fundamentado nos instintos naturais do homem em se defender e preservar sua própria vida. Na opinião do mesmo autor, numa como que síntese perfeita de distinção entre Hobbes e Espinosa, o direito natural de Hobbes nada tem de natural no sentido da apreensão da própria natureza, de suas leis físicas, seria antes a constatação de uma forte inclinação individual à sobrevivência.

Hobbes, só pressupunha a efetividade do direito natural fora do estado da natureza, após a criação de leis e instituições que, de alguma forma, regulassem e limitassem os impulsos e as paixões naturais dos indivíduos.

Segundo ele, no estado natural não haveria espaço algum para qualquer direito, dada a inexistência de limites, de sanções externas que impedissem o livre agir. Era uma completa beligerância permanente, uma guerra de todos contra todos, de onde o conceito de homo homini lupus. Sem a cobertura das leis, só a força bruta seria capaz de subjugar e impor obediência.

${ }^{25}$ FRATESCHI, Yara. A física da política: Hobbes contra Aristóteles, apud MASCARO, Alysson Leandro. Filosofia do Direito. São Paulo: Editora Atlas S.A. 2010, p. 167.

${ }^{26}$ MASCARO, Alysson Leandro, op. cit. p. 167. 
Para Hobbes, o direito natural nasceria, então, a partir da constituição do próprio Estado, o qual submeteria os indivíduos por meios de seus decretos e instituições e anulando, consequentemente, a vigência do estado natural. Por conseguinte, o ser humano em seu estado natural, privado de qualquer organização, fosse estatal, fosse associativa, jamais se conduziria de molde a seguir um padrão de conduta que sugerisse a existência de quaisquer regras, muito menos um possível direito.

Já para Espinosa, era totalmente desnecessária, ou até absurda em termos, a presença do Estado para a existência do direito natural. Este era resultado da capacidade plena de agir das pessoas, de suas potências naturais, na busca da autopreservação. Esse direito natural independeria, ou até excluiria, a presença de quaisquer instituições.

Embora a busca do ser humano pela autopreservação fosse um tema caro aos dois filósofos, os fins, os móbeis, eram, no entanto, diferentes. Assim, Leo Strauss ${ }^{27}$ comenta:

\begin{abstract}
"Ainda que a doutrina do Estado repouse em Espinosa no reconhecimento da tranquillitas animi como fim último da vida, a doutrina hobbesiana do homem - e portanto a teoria do Estado em Hobbes - tem como princípio a rejeição deste summum bonum dos 'antigos filósofos da moral': a ideia de um summum bonum está em contradição com a essência da vida, quer dizer, da vida atual (Léviathan, XI). Os dois filósofos veem a essência do homem na autopreservação, mas eles visam, sobre o mesmo tema, a duas coisas bem diferentes. A autopreservação que se compreende verdadeiramen leva à teoria em Espinosa, e à segurança do futuro, à paz ao Estado, em Hobbes".
\end{abstract}

Ou seja, ainda que os dois filósofos vissem na autopreservação a essência do ser humano, o significado dado a ela pelos dois era diferente: em Hobbes, essa busca pela autopreservação levaria à criação do Estado, com o escopo principal do estabelecimento da paz e da segurança; para Espinosa essa busca deveria tender à tranquilidade do espírito, à busca da sabedoria, e o Estado seria apenas uma decorrência lógica.

Segundo este autor, portanto, o fim último da doutrina moral e política hobbesiana é a procura da paz e da segurança: sua concepção de direito natural, bem como da sua doutrina moral são rigorosamente idênticas.

${ }^{27}$ STRAUSS, Leo. La Critique de la Religion Chez Spinoza. Paris: Les Editions du Cerf, 1996, p. 278. 
A esta posição de Strauss, que enxergava na criação do Estado o fim último da paz, da tranquilidade, e até da sabedoria, Antonio Negri ${ }^{28}$ contrapõe que o verdadeiro fim que importa de um Estado, segundo Espinosa, é a constituição da liberdade. Nas próprias palavras do filósofo "Finis revera Reipublicae libertas est", ou seja, o verdadeiro fim do Estado é a liberdade. E esta liberdade teria de ser vista como a autonomia do sujeito coletivo. Mas já para Susan James ${ }^{29}$, um estudo sistemático dos dois tratados políticos espinosianos permitirão enxergar que a segurança e a liberdade estariam umbilicalmente ligadas e uma não poderia ter existência sem a outra.

Em Espinosa a sua concepção de direito natural não tem qualquer ligação com sua doutrina moral e política. Direito natural é conforme às leis da natureza, e não a quaisquer concepções morais, políticas ou filosóficas. Como afirma Antonio Negri ${ }^{30}$, há uma relação entre o desenvolvimento dos desejos individuais e a constituição do sujeito coletivo, que é realmente o objeto da política, e não é objeto nem da moral, muito menos da religião.

Leo Strauss ${ }^{31}$ afirma que Hobbes parte da condição natural dos homens, da total ausência de Estado, e que esta mesma situação não seria interessante para eles, não bastava a satisfazer as necessidades humanas, devido à guerra de todos contra todos que se instalaria forçosamente. O que teria feito nascer o Estado, como já reiterado, seria o interesse pela paz, pela autopreservação.

A partir da situação do ser humano privado do Estado, Hobbes define o direito da natureza: apesar de fonte de todo o direito, ele não se identifica completamente com a conduta efetiva dos homens, já que em grande parte essa conduta é contrária à razão. E, no entanto, o direito da natureza deveria ser conforme à razão. Mas como o maior bem para os indivíduos é a sua conservação, e o pior mal é a morte, e determinados bens não podem ser partilhados, mas disputados, é até compreensível, e não condenável, essa luta dos indivíduos pela sobrevivência. Ora, o que é conforme às exigências naturais da razão pela

\footnotetext{
28 NEGRI, Antonio, op. cit. p. 43.

29 JAMES, Susan. A democracia e a boa vida na filosofia de Espinosa. In: HUENEMANN, Charlie (Ed.) Interpretando Espinoza: ensaios críticos. São Paulo: Madras, 2010, p. 164.

${ }^{30}$ NEGRI, Antonio, op. cit. p. 43.

${ }^{31}$ STRAUSS, Leo, op. cit. p. 279.
} 
sobrevivência, tem de ser conforme ao direito, significando este a liberdade de cada um se preservar. Daí se segue que o primeiro fundamento do direito da natureza é que cada um proteja sua vida e de seus membros de sua família ou tribo de acordo com suas forças.

Já Espinosa, segundo o mesmo autor ${ }^{32}$ parte do direito da natureza e define o estado da natureza a partir dele. E, fundamentalmente, não é a partir do ser humano que ele constrói o seu conceito de direito natural, pois todos os seres existentes, não apenas os seres humanos, têm tanto direito natural quanta potência eles possuem.

$\mathrm{Na}$ verdade, a potência de cada ser existente, que os faz existir e agir, não é propriamente sua, mas oriunda da potência eterna e infinita de Deus. E é esta potência eterna e infinita a fonte originária de todas as potências singulares e finitas, de todos os direitos, identificando, assim, direito e potência. Portanto, já que as supremas leis da natureza condicionam todo o indivíduo ao esforço pela autopreservação, segue-se que cada ser, inclusive o humano, tem o direito de buscar a sua preservação a qualquer custo.

Espinosa, portanto, parte de Deus para o estabelecimento do direito natural, enquanto que Hobbes parte do homem, de sua existência concreta, das necessidades deste para definir o seu direito da natureza.

Segundo Leo Strauss ${ }^{33}$, embora com fundamentos diferentes, ou seja, fundamento metafísico em Espinosa, e fundamento natural existencialista em Hobbes, o resultado é o mesmo: há sempre uma ligação entre direito natural e tendência à autopreservação.

Do princípio metafísico espinosiano "o direito de Deus é a sua potência" segue-se que os seres humanos não são apenas condicionados ou patrulhados por sua razão, mas por todas as suas forças, paixões e instintos mais intrínsecos. Tentam sempre buscar tudo o que estes impulsos exigem.

Este princípio metafísico é apto a legitimar estados de ânimo potencialmente agressivos, belicosos, tais como o ódio, a cólera, todas as desarmonias possíveis, pois tudo isso estaria de acordo com as leis da natureza. Só a razão, suplantando

32 STRAUSS, Leo, op. cit. p. 280.

${ }^{33}$ Ibid., p. 281. 
esta situação, poderia tentar implementar uma relação de convivência harmônica, de modo a otimizar a realidade concreta existente.

Para Hobbes ${ }^{34}$, o direito da natureza seria apto a fundamentar o Estado, e acima de tudo, a legitimá-lo. Também para ele os conceitos de direito, de erro, de justiça e de injustiça não teriam lugar no estado de natureza, tal como queria Espinosa. Cada um poderia, a título de reivindicação razoável e nunca condenável, aplicar segundo seus próprios critérios todos os meios necessários à sua conservação. Mas a doutrina espinosiana legitima o uso da força pelos indivíduos, não apenas ancorados no uso da razão tal como pretendia Hobbes, mas também legitimados no apelo inato das paixões e instintos.

Tal como explicado por Leo Strauss ${ }^{35}$ :

\begin{abstract}
"Como já se viu, Hobbes, diferentemente de Espinosa, parte do estado da natureza e legitima o direito natural pela razão do homem que vive neste estado. Este direito da natureza é perfeitamente ilusório porque leva à guerra de todos contra todos, e pois a uma situação na qual a conservação da vida e da saúde é impossível. E é por isso que procurar a paz é um comando da verdadeira razão. Tal é, diferentemente do direito da natureza, a lei da natureza fundamental. (...) As leis da natureza são a expressão das condições que estão no fundamento da anulação do estado de natureza em proveito do Estado da sociedade politicamente constituída, anulação que a razão exige".
\end{abstract}

Concluindo, ao contrário de Espinosa, Hobbes, partindo do estado bruto, cru, da natureza, legitima o direito da natureza pelo uso da razão do ser humano que tenta a todo o custo sobreviver nesse estado impiedoso. Mas esse hipotético direito da natureza seria completamente inútil porque levaria à guerra de todos contra todos, tornando a vida impossível. Seria por esse motivo, que a busca da paz se transformaria no principal móbil da criação do Estado e, consequentemente, na própria eliminação de tal estado da natureza em prol da constituição de uma sociedade organizada segundo leis preestabelecidas.

Ainda segundo Leo Strauss ${ }^{36}$, uma dessas importantes leis fazia referência ao respeito absoluto aos contratos livremente estabelecidos. E o contrato constitutivo da sociedade política repousa na validade desta norma jusnaturalista. E o próprio Hobbes $^{37}$ nos dá o seguinte exemplo, mostrando a importância da obediência

\footnotetext{
${ }^{34}$ STRAUSS, Leo, op. cit. p. 283.

35 Ibid., p. 284.

36 Ibid., p. 285.

37 Ibid.
} 
cega aos contratos e da necessidade de seu cumprimento: se eu, temendo pela vida, prometo a um bandido de lhe enviar determinada quantidade de ouro se ele me deixar ileso, e nada fazer para desmascará-lo às autoridades constituídas, ficaria preso a essa promessa caso conseguisse salvar-me? Sim, ficaria totalmente atado a essa promessa pela seguinte razão: se não mantivesse a minha promessa, e denunciasse esse delinquente, amanhã ou depois outros cidadãos poderiam correr riscos semelhantes e não teriam essa oportunidade de salvação, já que os delinquentes poderiam não acreditar mais em suas promessas.

E concluindo com Leo Strauss ${ }^{38}$, o mesmo contrato hipotético em que se baseia a criação da sociedade política tem os mesmos fundamentos do caso exemplar atrás mencionado. Pois na verdade, este mesmo hipotético contrato constitutivo do Estado é, também, fruto de uma extorsão, já que é resultado do medo, da angústia de se perder a vida, mas nem por isso ele pode ser considerado nulo ou inválido.

É deste modo que é preciso compreender Hobbes: o medo como fomentador da paz e legitimador do Estado. Pois o comportamento pacífico no meio de uma guerra generalizada é contrário à própria razão, e o resultado não seria a paz e sim a morte. Daí que a paz pressupõe a criação de um Estado, de preferência forte, que constranja legitimamente a fim de trazer segurança.

Mas Espinosa tinha uma opinião diametralmente oposta. Ele não fazia derivar o desejo que o ser humano tem pela paz, pela segurança, do medo da morte, levando-o, pois, a fundar o contrato constitutivo da sociedade política. Espinosa rebate o exemplo de Hobbes, atrás mencionado, chegando a uma conclusão distinta:

"O compromisso tomado verbalmente em relação a alguém de fazer ou, pelo contrário, de não fazer tal ou tal coisa, quando se tem o poder de agir contrariamente à palavra dada, permanece em vigor enquanto a vontade daquele que prometeu não se altera. Com efeito, quem tem poder para romper os seus compromissos de modo algum alienou os seus direitos, pois aqueles eram apenas verbais. Portanto, se aquele que é por direito de natureza seu próprio juiz julgou reta ou erroneamente (errar é próprio do homem) que o compromisso tomado terá para si consequências mais nocivas que úteis e se considera em sua alma que tem interesse em quebrar 0 compromisso, quebrá-lo-á por direito natural." 39

38 STRAUSS, Leo, op. cit. p. 285.

39 ESPINOSA. TRATADO POLÍTICO, op. cit. p. 318. 
Esta posição é baseada no fato de Espinosa identificar direito e potência natural. Se a sua potência the permitir, o ser humano poderá quebrar qualquer compromisso antes assumido, se isso lhe parecer útil para a sua preservação. Trata-se de pura lei natural. Ou seja, se eu tiver o poder de romper o contrato, e isso se me afigurar interessante ou benéfico, rompê-lo-ei legitimamente pelas leis da natureza.

Segundo Leo Strauss ${ }^{40}$, enquanto para Hobbes a dita fidelidade aos contratos constituía a ponte entre a autopreservação e a constituição da sociedade política, para Espinosa esta constituição tinha outras causas. Embora o interesse pela formação de uma sociedade policiada possa surgir do medo, este medo não é suficiente para fazer um verdadeiro cidadão.

É preciso que uma outra razão venha pôr ordem no jogo das inúmeras potências em conflito. E essa razão está na busca do poder, do domínio, por alguém com mais força, mais potência natural, combinado com os interesses imediatos da multidão ignara. Esse hipotético sujeito, usando de artimanhas ou ardis, consegue dominar os espíritos mais fracos ou menos potentes e arregimentá-los, seja pelo medo, seja por promessas. E a arte da guerra mede-se pelo tamanho da astúcia dos líderes. Aqui, uma forte semelhança das ideias espinosianas com o pensamento de Maquiavel. E tal como este pensador, Espinosa também concorda que a habilidade política está em saber dosar e manejar o poder das ameaças com o dom das promessas.

Assim, a constituição de uma sociedade política terá nascido, não de um consentimento generalizado dos cidadãos, em busca da paz pela sua autopreservação, mas da ascendência de certos líderes, com mais poder ou astúcia, simulando poderes sobrenaturais, ou arvorando-se em descendentes de deuses ou por eles instruídos. Isto está mais patente nos antigos regimes teocráticos, mas todos os regimes, de uma forma ou de outra, seguem a mesma fundamentação.

Mas, um pouco contrariamente à interpretação que Strauss dava à ideia espinosiana da genealogia do poder e, portanto, da formação do Estado, para

40 STRAUSS, Leo, op. cit. p. 289. 
Negri ${ }^{41}$ este só pode ser fruto do consenso, e não de qualquer imposição ou ascendência de quem quer que seja. De fato, qualquer ruptura da norma consensual induzirá à guerra necessariamente, e a legitimará. Portanto, a genealogia do poder só pode ser democrática, e não fundada em gênese jurídica ou política.

Reitere-se que uma diferença muito importante na visão política sobre a constituição do Estado, está em que em Hobbes, como explica Alysson Leandro Mascaro ${ }^{42}$, a associação entre os homens levaria necessariamente à renúncia completa dos poderes individuais. E essa associação iria muito além de um simples pacto, pois todos os poderes individuais seriam transferidos ao Estado, seja na figura de um rei, ou até de uma assembleia, de modo a constituir-se o poder como fruto de uma só vontade. Nas palavras do autor "É preciso transferir as vontades subjetivas ao Estado que, como vontade única, age em todos os casos como se seus atos fossem os atos dos indivíduos".

Ainda, segundo Alysson Leandro Mascaro ${ }^{43}$, para uma determinada corrente política moderna, nela incluído Hobbes, o Estado constituído gerava uma instância de poder contrastante e distinta dos indivíduos que lhe deram origem. Para outra corrente, nesta incluídos Espinosa e Rousseau, a instância de poder formada pelo Estado constituído não poderia ser contrastante e distinta da vontade dos cidadãos que a originaram, pois estes é que continuariam como donos da vontade geral.

Como explica Bobbio ${ }^{44}$ :

"O que, quando muito, distingue Spinoza de Hobbes é que, enquanto para Hobbes o pacto de união pode ser configurado como um contrato em favor de um terceiro (como diria um jurista), para Spinoza - que nisso antecipa claramente Rousseau e o conceito tipicamente rousseauniano da liberdade política como autonomia - o próprio pacto de união prevê a transferência do poder natural de cada um para a coletividade da qual cada um é parte".

Ou, como diz Marilena Chauít5:

\footnotetext{
${ }^{41}$ NEGRI, Antonio, op. cit. p. 46.

${ }^{42}$ MASCARO, Alysson Leandro, op. cit. p. 164 - 165.

43 lbid.,. p. 151.

${ }^{44}$ BOBBIO, Norberto. Sociedade e estado na filosofia política moderna, apud MASCARO, Alysson Leandro. Filosofia do Direito, op. cit. p. 151.

${ }^{45}$ CHAUÍ, Marilena. Política em Espinosa, apud MASCARO, Alysson Leandro. Filosofia do Direito, op. cit. p. 152.
} 
"Podemos observar que, no Teológico-Político, Espinosa não aceita a ideia do pacto como transferência total do direito natural ou da potência individual a um outro: o pacto é descrito como um acordo mútuo em que cada indivíduo concorda em que o direito natural de cada um a todas as coisas seja exercido coletivamente e não mais seja determinado pelo apetite de cada um e sim pela potência da vontade de todos em conjunto (...).

Mas, como pretende Negri ${ }^{46}$, a teoria do contrato social é uma ficção sóciojurídica para legitimar a transferência do poder ao Estado e, consequentemente, fundamentar o conceito jurídico do poder desse mesmo Estado. Ora, em Espinosa, o Estado e a soberania não estão pressupostos nem nas leis, nem em um ordenamento constitucional, seja este fruto de um contrato social, ou de qualquer outro poder externo, como o divino, por exemplo. Antes, derivam de um processo contínuo de legitimação através do povo organizado por consenso. E só este processo contínuo de legitimação pelo consenso poderá ser fonte do poder e soberania. Na filosofia espinosiana não há lugar para qualquer transcendência de valores.

Ainda, é preciso não confundir direito natural exclusivamente com a potência humana de agir. Para Leo Strauss ${ }^{47}$, a doutrina espinosiana de direito natural não se refere exclusivamente à natureza humana: esta doutrina diz respeito ao Cosmos, pura e simplesmente. E como o ser humano faz parte desse Cosmos, detém por consequência uma pequena parcela desse direito natural, embora ínfima. A exiguidade e fraqueza dessa ínfima potência é, todavia, compensada, pelo uso da razão que faz com que se superem certos obstáculos à manutenção da vida. E é pela razão que os seres humanos constituem as sociedades políticas, visando um incremento da potência de agir e um maior domínio sobre os outros, e não apenas pelo medo da morte como queria Hobbes.

Em síntese, ambos os filósofos encaravam como direito natural dos indivíduos a busca permanente pela autopreservação. Mas, para Hobbes, encarando o homem como um ser naturalmente egoísta, esse direito natural conduziria fatalmente à guerra de todos contra todos, e não se tornaria efetivo. Só numa sociedade organizada, em que se transferisse todo o poder ao Estado, alienandose, assim, toda a potência e direito individuais, poderia haver alguma efetividade nos direitos então outorgados. Já para Espinosa, a organização política teria sido

${ }^{46}$ NEGRI, Antonio, op. cit. p.45.

47 STRAUSS, Leo, op. cit. p. 291. 
fruto do consenso dos cidadãos, justamente para aumentar suas potências individuais e se autopreservarem mais facilmente. Mas essa organização de origem consensual não implicaria, necessariamente, na alienação de todo o poder que o cidadão dispunha originariamente em seu estado natural. 


\section{O DIREITO NATURAL EM ESPINOSA}

\section{1. FUNDAMENTOS METAFÍSICOS DO DIREITO NATURAL}

Antes de analisarmos o conceito de direito natural de Espinosa, e para compreendermos toda a sua originalidade, necessário se torna expormos o núcleo de seu pensamento sobre metafísica e ética.

A essência do pensamento espinosiano em metafísica gira em torno de três conceitos distintos: substância, atributo e modo.

Substância seria a realidade eterna e imutável, a essência ou núcleo duro de toda a realidade, aquilo que é por si mesmo, não causado, mas causa de tudo o mais que existe, enfim, Deus. Na própria definição do filósofo 48 : "Por substância entendo o que existe em si e por si é concebido, isto é, aquilo cujo conceito não carece do conceito de outra coisa do qual deva ser formado". Seria a natura naturans, natureza criadora, cujas leis necessárias criaram tudo o que existe individualmente considerado, coisas, animais e o próprio ser humano, a natura naturata, que seriam os modos da existência. A primeira, substância, seria eterna; os segundos, os modos, seriam de ordem temporal, efêmeros, corruptíveis.

Por modo entendia Espinosa 49 "as afecções da substância, isto é, o que existe noutra coisa pela qual também é concebido". Segundo Chauí ${ }^{50}$, o modo é uma essência singular existente, determinado a existir pela substância, porém finito, pois, embora não deva haver em seu interior algo que o leve à destruição, a não ser uma anomalia, está limitado externamente por outros modos que o condicionam e o forçam à aniquilação. E essência é aquilo pelo qual uma coisa é o que é, dela faz parte e a condiciona.

${ }^{48}$ ESPINOSA. ÉTICA, op. cit. p. 84.

$49 \mathrm{lbid}$.

50 CHAUÍ, Marilena de Souza. A nervura do real: imanência e liberdade em Espinosa. São Paulo:

Companhia das Letras, 2006, p. 90. 
Já por atributos, seguindo a definição de Espinosa ${ }^{51}$, "por atributo entendo o que o intelecto percebe da substância, como constituindo a essência dela", deve-se entender os diferentes aspectos pelos quais a razão perceberia a realidade ou os processos da natureza, os quais para nós seriam basicamente o pensamento e a extensão, ou matéria. Apesar de, possível e logicamente, poder serem infinitos, a razão humana só consegue perceber a existência dos dois.

Frise-se que, para Espinosa, atributo não pode ser considerado como um mero apêndice, um predicado de determinado sujeito, antes, deve ser considerado como uma propriedade essencial da substância. Ou seja, atributo não pode ser considerado como um aspecto visto de um modo particular, subjetivo, mas o que a razão consegue perceber como sendo a própria essência da substância. Assim, para Chauí ${ }^{2}$, atributo é o que nosso intelecto finito, nosso entendimento limitado, consegue perceber como sendo a essência da substância, embora não passe de um predicado extrínseco, já que essa mesma substância, porque infinita e indivisível, é-nos inacessível e incognoscível.

Como substância, Deus é a condição fundamental de todas as coisas existentes, das leis e das estruturas de todo o Universo, ou dos Universos possíveis e desconhecidos. É o que se deduz das seguintes passagens: "Afora Deus, não pode ser dada nem concebida nenhuma substância" 53 e "Tudo o que existe, existe em Deus, e sem Deus nada pode existir nem ser concebido". ${ }^{4}$

A vontade de Deus se revela nas próprias leis da natureza, criando miríades de coisas efêmeras, os modos, segundo regras absolutamente necessárias e invariáveis, num determinismo imutável. É o que se deduz da seguinte proposição: "Da necessidade da natureza divina devem resultar coisas infinitas em número infinito de modos, isto é, tudo o que pode cair sob um intelecto infinito" 55 . E o ser humano, que também não passa de um modo particular, singular, porque dotado da consciência de suas ações, julga erroneamente estar no comando das mesmas e enxerga, quase sempre, finalidades antropocêntricas nos inúmeros processos vitais, os quais não têm essa finalidade, mas são

51 ESPINOSA. ÉTICA, op. cit. p. 84.

${ }^{2}$ CHAUÍ, Marilena, op. cit. p. 807.

${ }^{53}$ ESPINOSA. ÉTICA, op. cit. p. 96.

54 Ibid., p. 97.

55 Ibid., p. 100. 
causados por processos necessários que escapam à sua compreensão. É o que se conclui de "(...) os homens têm consciência das suas ações, mas são ignorantes das causas pelas quais são determinados" 56 .

Dessa forma, como o filósofo explica ${ }^{57}$,bem e mal são conceitos subjetivos, criados pelo homem, mas que não se amoldam, não se adequam à realidade eterna da natureza, como, do mesmo modo, beleza e fealdade não passam também de conceitos meramente subjetivos, meros preconceitos incognoscíveis e irreconhecíveis pela realidade eterna.

Segundo a filosofia de Espinosa, Deus não é um Ser distinto do mundo, alheio e independente dele, mas, ao contrário, identifica-se completamente com este mesmo mundo, como substância perene, eterna, e não sujeita a mudanças como os modos, ou coisas, que Ele mesmo cria. É causa imanente de tudo, numa cadeia necessária de acontecimentos e processos, ainda que Espinosa $O$ considere como a única causa livre que existe.

Explicando melhor, segundo Chauí 58 , Deus é causa primeira, eficiente, imanente e não transcendente e, acima de tudo, causa absolutamente livre. Causa primeira, porque Deus é causa de todas as coisas, sem ser causado por nenhuma delas anteriormente, já que Deus preexiste a todas as coisas. É causa eficiente, já que produz toda uma gama de efeitos que são coisas reais. É causa imanente e não transcendente, porque a essência divina não funciona simplesmente como causadora de efeitos a ela exteriores, mas é essencialmente atividade pura, já que as coisas geradas como efeitos a ela são inerentes, pertinentes.

Ainda segundo a mesma autora ${ }^{59}$, esta causa eficiente e imanente é diferente de uma causa eficiente transitiva, porque esta pressupõe 0 afastamento, 0 desligamento, entre causa e efeito, numa ruptura irreversível entre ambos, enquanto aquela exige a permanência da causa nos efeitos por ela gerados, efeitos esses que modificam a própria causa e são aptos a produzir outros efeitos necessariamente. E é causa absolutamente livre porque Deus age unicamente

\footnotetext{
56 ESPINOSA, ÉTICA, op. cit. p. 166.

57 Ibid., p. 234.

58 CHAUÍ, Marilena, op. cit. p. 865 - 867.

59 Ibid., p. 874.
} 
pela perfeição de sua natureza, sem ser instado a produzir isto ou aquilo por qualquer causa endógena ou exógena.

Assim, explica a autora ${ }^{60}$, não há qualquer causa intrínseca, seja o intelecto, ou a vontade, ou qualquer noção de justiça ou misericórdia, que seja apta a produzir a ação divina. Mais ainda, também nenhuma causa extrínseca $O$ poderá demover, seja para suprir alguma carência ou defeito de alguma criatura, seja para estornar algum excesso porventura gerado. E "é por agir exclusivamente pela necessidade de Sua natureza ou pela perfeição de Sua essência que somente Ele é causa livre, (conforme definição I,7, ÉTICA) a qual desliga liberdade e contingência e, portanto, liberdade e vontade" 61 .

Todos os outros seres, ainda que em sua atividade e existência possam causar diversos e múltiplos efeitos, o fazem numa cadeia necessária, predeterminada fisicamente, inclusive o ser humano.

Apesar de o ser humano poder agir, em certo sentido, racionalmente, tentando enxergar finalidades e tendo a ilusão da consciência de poder efetuar escolhas livremente e alcançar resultados, no fundo ele sempre age por impulsos necessários que ele mesmo desconhece. Assim, para Espinosa ${ }^{62}$ :

\footnotetext{
"Os homens enganam-se quando se julgam livres, e esta opinião consiste apenas em que eles têm consciência das suas ações e são ignorantes das causas pelas quais são determinados. O que constitui, portanto, a ideia da sua liberdade é que eles não conhecem nenhuma causa das suas ações".
}

Desta causalidade necessária inscrita em toda a natureza, emerge o conatus, que nada mais é que o esforço que cada ser desenvolve necessariamente para se autopreservar. O conatus de um ser é, portanto, o esforço desse ser em se manter íntegro, conservar a sua natureza, o qual registra diversos graus de aperfeiçoamento, sendo maior no ser humano.

Esse esforço pela preservação do ser, pela manutenção da sua natureza, sofre diversas limitações, sendo umas internas, e outras externas. As limitações internas derivam da própria essência do indivíduo, essência essa que lhe confere determinadas propriedades e características, estando esse indivíduo limitado,

\footnotetext{
60 CHAUÍ, Marilena, op. cit. p. 867.

61 Ibid., p. 867.

62 ESPINOSA. ÉTICA. op. cit. p. 166.
} 
confinado, a esse código originário. Ele jamais poderá reverter o que está escrito nesse código, não podendo ir além das possibilidades aí fixadas, porque não tem autonomia nem capacidade para superar essas barreiras.

Já as limitações externas dizem respeito a uma ordem relacional com os outros indivíduos, pertençam eles à mesma espécie ou não, e com a própria realidade que o cerca. Determinado indivíduo encontrará resistência no choque com o ambiente circundante, seja ele de indivíduos da mesma espécie, buscando os mesmos bens e resultados que ele procura, seja de indivíduos de outras espécies, os quais, no final das contas, acabam também por entrar em competição com ele de uma forma ou de outra.

Assim, enquanto Deus possui uma potência infinita, todos os indivíduos possuem uma potência finita, ditada por sua natureza, apta em tese à consecução dos fins e resultados necessários à manutenção dessa mesma natureza e confiando-Ihes os direitos equivalentes.

E a procura das condições necessárias à sobrevivência é que fundamenta a ética espinosiana, podendo estabelecer-se a sua base na busca de tudo aquilo que é útil à autopreservação de todo o ser. E esta utilidade buscada com frenesi a todo o instante, na manutenção da vida, é que deve ser o baluarte de qualquer ética. $E$ Negri63, a partir da afirmação de Espinosa, de que nada é mais útil ao homem que o próprio homem, desenvolve todo um escopo político coletivo a partir dessa sua base ética. A ética fundamentaria assim toda a política e o associar-se coletivo.

E esta busca da utilidade, no caso do ser humano, seria tanto mais profícua, quanto mais ela for guiada pela razão, e pelo conhecimento daí advindo. Já que o indivíduo, dentro da cadeia necessária dos acontecimentos, é constantemente instado pelo conatus a buscar o útil à sua preservação, e como esse conatus só Ihe confere uma dada potência limitada, a razão, o conhecimento, e a adesão a outros seres semelhantes poderiam muito bem amplificar essa potência na busca do útil necessário à sobrevivência.

E é esta potência de cada ser que vai legitimar, no final das contas, o direito de cada um. "Tantum juris quantum potentiae", é esta máxima metafísica que,

63 NEGRI, Antonio, op. cit. p. 80. 
segundo Negri ${ }^{64}$, vai fundamentar todo o pensamento jurídico e político de Espinosa.

Em síntese, o conceito de direito natural e de toda a construção política como decorrência dele, está todo assente nos fundamentos metafísicos da potência natural e no conatus, este como sendo o esforço de autopreservação. Essa potência e esse conatus é que fundamentarão a ética como a busca do útil e ditarão as regras da construção do direito e das sociedades.

${ }^{64}$ NEGRI, Antonio, op. cit. p. 46. 


\section{2. CONCEITO DE DIREITO NATURAL}

Numa análise inicial, como contraponto ao chamado direito positivo, aquele direito legislado pelos estados, tomemos o significado comum de direito natural tal como exposto por Camilo Onoda Caldas ${ }^{65}$ :

"O direito natural é exatamente aquele que afirma ser possível conhecer o direito ou pela observação da "natureza das coisas", ou pela revelação divina ou pelo uso da razão. Qualquer uma das três formas de conhecer o direito revela que num determinado momento o direito foi considerado como um objeto cujo conhecimento se daria independentemente da articulação com um método; o apelo à "justa medida", à fé ou ao "bom senso" nos levaria a conhecer o que distingue o direito de outros fatos existentes no mundo".

Mas, para Espinosa a definição de direito natural é outra66:

"Por direito natural, portanto, entendo as próprias leis ou regras da Natureza segundo as quais tudo acontece, isto é, o próprio poder da Natureza. Por conseguinte, o direito natural da Natureza inteira, e consequentemente de cada indivíduo, estende-se até aonde vai a sua capacidade, e portanto tudo o que faz um homem, seguindo as leis de sua própria natureza, fá-lo em virtude de um natural soberano, e tem sobre a Natureza tanto direito quanto poder. (...) Mas os homens são mais conduzidos pelo desejo cego do que pela Razão, e por conseguinte, a capacidade natural dos homens, isto é, o seu direito natural, deve ser definido não pela Razão, mas por toda a vontade que os determina a agir e através da qual se esforçam por se conservar (...) quer seja conduzido pela razão, ou apenas pelo desejo, o homem, efetivamente, nada faz que não esteja conforme com as leis e as regras da Natureza, isto é, em virtude do seu direito natural."

Aqui, de uma forma cristalina, o que Espinosa entendia por direito natural, que passaremos a desenvolver. Nada mais, nada menos, direito natural seria a capacidade, a potência natural, do indivíduo se conduzir de acordo com as leis e as regras da natureza, regras essas inseridas tanto nos instintos e impulsos naturais, quanto na sua razão. Corresponderia, pois, à sua plena capacidade de agir, à sua potência finita, na busca incessante de sua plena realização e, acima de tudo, na luta árdua pela sobrevivência.

Dito de uma maneira singela, direito natural equivaleria à capacidade de agir e de sobreviver, à sua potência natural. Quanto mais poderes um indivíduo desfrutasse, quanto mais potência detivesse, mais direitos deteria e vice-versa.

65 CALDAS, Camilo Onoda et alii. Manual de Metodologia do Direito: Estudo e Pesquisa - São Paulo: Quartier Latin, 2010, pág. 93 - 94.

66 ESPINOSA. TRATADO POLÍTICO. São Paulo: Ed. Abril, 1르 Ed., 1973, p. 315. 
Direito igual a poder. Quanto mais força de submeter os outros a si mesmo, ou até o meio, mais direitos exerceria. E muito importante é verificar que seria de todo irrelevante a origem ou o móbil desse poder. Fosse ele oriundo da razão ou entendimento humano, ou nascesse dos instintos ou paixões, pouco importaria para o caso. Seja se comportando de acordo com um entendimento racional, seja se conduzindo de molde a satisfazer seus instintos vitais de satisfação, sempre o ser humano estaria exercendo suas faculdades e potencialidades conforme as leis da natureza, ou seja, exercendo a sua potência natural, equivalente a direito natural. Citando Espinosa67:

Mas, como se trata aqui do poder universal da Natureza, que é a mesma coisa que o
direito natural, não podemos reconhecer neste momento nenhuma diferença entre os
desejos que a Razão engendra em nós e os que têm outra origem; uns e outros,
efetivamente, são efeitos da Natureza e manifestam a força natural pela qual o
homem se esforça por perseverar no seu ser. Quer seja sábio ou insensato, o homem
é sempre parte da Natureza, e tudo aquilo através do qual é determinado a agir deve
ser relacionado com o poder da Natureza, tal como este pode ser definido pela
natureza deste ou daquele homem. Quer seja conduzido pela Razão ou apenas pelo
desejo, o homem, efetivamente, nada faz que não esteja conforme com as leis e as
regras da Natureza, isto é, em virtude do direito natural. Ou seja, no estado natural, aqui entendido como aquela situação em que os indivíduos dispunham de toda a liberdade natural possível, sem estar confinados a quaisquer regras ou amarras convencionais, a cânones ditados posteriormente pelas instituições criadas pelos seres humanos, nesse estado natural, e só nesse estado, o ser humano já exerceria plenamente o seu direito natural.

Para Espinosa, nos primórdios da existência da humanidade, muito tempo antes da constituição das sociedades organizadas e hierarquizadas, o isolacionismo do ser humano Ihe conferia uma total libertação, em que as noções do certo e do errado, do lícito e do ilícito, do justo e do injusto não eram conhecidas e experimentadas, nada significavam, nenhuma importância detinham para o gênero humano. Força, direito e potência se identificavam, se confundiam. Assim, de acordo com Espinosa ${ }^{68}$ :

"Nada pode existir em estado natural que possa ser chamado de bom ou mau por
assentimento comum, já que cada homem, que está em estado natural, consulta
apenas sua própria vantagem e decide o que é bom ou ruim conforme seu próprio
capricho e na medida em que considera apenas sua própria natureza e não se
considera responsável para com ninguém a não ser para consigo mesmo; e,
consequentemente, o pecado não pode ser concebido num estado natural, mas

${ }^{67}$ ESPINOSA. TRATADO POLÍTICO, op.cit. p. 316.

68 Idem. ÉTICA, op. cit. p. 256. 
somente num estado civilizado, onde é decretado por assentimento comum o que é bom ou mau e onde cada um é responsável perante a sociedade".

Como salienta Steven Nadler ${ }^{69}$ a qualificação de um ato como mau ou pecaminoso não tem qualquer relação com a realidade da natureza. Essa qualificação não passa de mera projeção do nosso julgamento subjetivo sobre todas as coisas existentes. Não existe uma perfeição ou orientação divinas, impondo regramentos morais a ser cumpridos e respeitados a qualquer custo. Estes regramentos só vieram após a constituição das sociedades organizadas e com o objetivo de preservá-las.

Nessa mesma linha de raciocínio e chegando à mesma conclusão, ainda que pela via empirista do conhecimento obtido através dos sentidos, e não pela via racional espinosiana, Hume, citado por Alysson Leandro Mascaro ${ }^{70}$, afasta a possibilidade de que a ideia do justo e da justiça como um todo sejam ideias absolutas, eternas, imutáveis. Para esse filósofo empirista, só a experiência seria a fonte de todo o conhecimento, e, portanto, a noção jurídica do justo seria puramente artificial, fruto das convenções.

Ainda, de acordo com Negri ${ }^{71}$, a única fonte criadora e legitimadora das noções do justo, do lícito, e, portanto, de todo o direito, seja este civil, penal ou constitucional, é a multitudo, ou seja a sociedade organizada, que, assim, se transforma no único sujeito coletivo político e jurídico, criadora, além do Estado e do direito, também da própria moral.

De onde se conclui que se o indivíduo, para satisfazer um instinto natural, ou suprir uma necessidade premente, se confronta com uma norma social, seja ela moral ou legal, ele não estará violando qualquer regra da natureza. A própria natureza ditou-lhe esse procedimento, e a resistência de seu comportamento instintivo às normas sociais ou legais, demonstrará a quantidade de potência natural de que esse indivíduo é capaz, guiado por suas necessidades prementes, não necessariamente por um comportamento racional.

\footnotetext{
69 NADLER, Steven. "Tudo o que existe está em Deus": a substância e as coisas na metafísica de Espinoza. IN: HUENEMANN, Charlie. Interpretando Espinoza: ensaios críticos, op. cit. p. 81.

${ }^{70}$ MASCARO, Alysson Leandro, op. cit. p. 143.

${ }^{71}$ NEGRI, Antonio, op. cit. p.72.
} 
O direito natural é encarado de um ponto de vista puramente objetivo, decorre da natureza singular do ser humano, aqui visto como um "modo" efêmero da substância divina, detentor, portanto, de uma potência limitada, proporcional à realização de sua essência.

Fazendo parte da natureza, o ser humano está sujeito apenas às suas leis, numa causalidade necessária, equivalendo o seu direito exatamente à sua capacidade de agir. De onde, tudo o que um ser, seja ele humano ou não, realiza, deriva de uma necessidade natural, de molde a atingir um escopo necessário, sem necessidade de qualquer legitimação, seja da sua consciência, seja de qualquer imposição externa. Sentiu necessidade, o ser praticará o ato de acordo com sua natureza, tendo como limites sua potência interna e a potência externa de seus competidores. E, como o ser humano, todos os demais seres da natureza têm também a sua parcela de direito natural, que equivale, da mesma forma, à sua capacidade de agir e de sobreviver, à sua potência. Assim, de acordo com Espinosa ${ }^{72}$ :

"Por direito e instituição da natureza não entendo outra coisa senão que as regras da
natureza de cada indivíduo, regras segundo as quais concebemos cada ser como
determinado a existir e a comportar-se de uma certa maneira. Por exemplo, os peixes
estão determinados pela Natureza a nadar, os peixes grandes a comer os pequenos,
em virtude de um direito natural soberano. É certo, com efeito, que a Natureza
considerada absolutamente tem um direito soberano sobre tudo o que está em seu
poder, quer dizer que o direito natural se estende tão longe quanto se estende o seu
poder; pois a própria potência da natureza é a mesma potência de Deus, que tem
sobre todas as coisas um direito soberano".

O direito se confunde assim com as próprias leis naturais, as quais atribuem determinadas propriedades intrínsecas a certos indivíduos, determinadas potências singulares, a fim de eles poderem realizar o que está predeterminado em seus códigos natos inerentes.

Não poderá o direito natural ser considerado, portanto, como uma faculdade subjetiva ou objetiva, seja ligada a concepções morais, sociais ou legais, então absolutamente inexistentes.

A legitimação desse direito está na própria existência do ser singular, dotado de uma potência finita, limitada à sua natureza. Como diz Hadi Rizk ${ }^{73}$, se o direito se

72 ESPINOSA. TRATADO TEOLÓGICO-POLÍTICO, apud RIZK, Hadi, COMPREENDER SPINOZA, 2. Ed. Petrópolis/RJ: Editora Vozes, 2010, p. 159.

${ }^{73}$ RIZK, Hadi, op. cit. p. 161. 
confunde com o fato, isso significa, simultaneamente, que esse mesmo direito não poderá exceder os limites da potência respectiva. A força de cada ser está limitada à sua essência de coisa singular e finita, a qual depende para existir de uma causa infinita não causada. E o mesmo autor, esclarecendo o pensamento espinosiano, fixa como limites intransponíveis do direito a finitude de sua potência. Esses limites tanto podem ser internos, determinados pela essência de cada ser com a atribuição de certas propriedades e exclusão de outras, quanto externos, uns impostos por outros seres singulares numa luta pela sobrevivência, outros pelo próprio meio ou natureza para quem a singularidade é de somenos importância.

Mas é preciso observar que este estado natural, onde impera o direito natural, não pode ser atribuído, apenas, a um determinado momento histórico, aos primórdios da civilização, etapa inicial evolutiva da sociedade. Ele continua presente em nossas vidas atuais, mesmo após o surgimento do estado e das instituições e de toda evolução eventual que porventura tenha acontecido.

Como bem interpreta Hadi Rizk ${ }^{74}$, o direito natural se traduz em múltiplos sentimentos de que o ser humano é presa, nomeadamente a rivalidade, o ódio, a cólera, sentimentos esses presentes em todos e em todas as épocas, não pertencendo só e exclusivamente à etapa inicial do surgimento do ser humano. Portanto, mesmo que um comportamento viole os mandamentos impostos por uma determinada racionalidade normativa, não é necessariamente contrário às leis da natureza, e assim terá de ser entendido. Ainda que os seres humanos considerem mais vantajoso viver segundo as leis de uma sociedade organizada, ainda que a razão pondere os prós e contras de agir de acordo com este ou aquele comportamento, ainda assim os instintos naturais e as paixões poderão determinar um comportamento transgressor do padrão normativo, sem que se possa denominar esse comportamento como antinatural e absurdo.

Mas, continua o mesmo autor, há paixões inatas, tais como o medo da morte, o impulso pela segurança, que poderão reforçar os móbeis racionais de comportamento, fazendo os seres humanos obedecer naturalmente a cânones

${ }^{74}$ RIZK, Hadi, op. cit. p. 162. 
legislativos artificiais ditados pela sociedade, de modo a tornar a vida mais segura, e assim ampliar as suas potências naturais.

E é com esse objetivo de aumentar as potências individuais, de multiplicá-las, que os indivíduos resolvem se unir, subordinando-se a um poder coletivo que regule ou limite as capacidades singulares com o fim de obter um benefício maior. Citando Espinosa ${ }^{75}$ :

"Se duas pessoas concordam entre si e unem as suas forças, terão mais poder conjuntamente e, consequentemente, um direito superior sobre a Natureza que cada uma delas não possui sozinha e, quanto mais numerosos forem os homens que tenham posto as suas forças em comum, mais direito terão eles todos".

Ainda de acordo com Hadi Rizk ${ }^{76}$, o indivíduo resolve aceitar os direitos que a comunidade Ihe outorga, renunciando a outros possíveis em sua esfera de atuação, mas, em contrapartida, esses direitos concedidos são reais porque efetivos, garantidos que são por instituições criadas para esse fim. Como a potência de cada indivíduo é limitada, e potência equivale a direito natural, o ser humano é levado a constituir uma rede de relações com outros, de modo a aumentar e a preservar sua potência, numa reciprocidade consentida, porém sempre negociada.

Pois, como assevera Negri ${ }^{77}$, para Espinosa só o homem é dono de si mesmo. O seu pensamento político é revolucionário porque destrói o jusnaturalismo em seus dois fundamentos: o individualismo e o contratualismo. Não há qualquer legitimação para uma transferência que aliene o poder e a potência de cada cidadão. Toda alienação resta eliminada, seja a concedida por Hobbes aos regimes absolutistas, seja a concedida pelos contratualistas modernos aos revolucionários burgueses, numa utopia transcendental em nome de uma vontade geral.

Em síntese, o direito natural para Espinosa nada tem a ver com a concepção jusnaturalista de ideias inatas e eternas sobre o justo e o lícito, nem com a concepção hobbesiana no atinente à alienação desse mesmo direito ao Estado absolutista para preservá-lo do homem egoísta e mau. Também não coincide com a pretensão dos modernos contratualistas alienando à sociedade burguesa o

75 ESPINOSA. TRATADO POLÍTICO, op. cit. p. 318.

${ }^{76}$ RIZK, Hadi, op. cit. p. 163.

77 NEGRI, Antonio, op. cit. p. 52. 
poder da vontade geral como utopia transcendental. Direito natural seria igual à potência de cada ser buscar o que the é útil à sua preservação. E se essa potência individual puder se amplificada numa relação com o coletivo, tanto melhor, mas sem, de modo algum, alienar e transferir a essência de seu poder. Esta transferência sempre terá de ser negociada, consentida, passo a passo. 


\section{ESTADO E POLÍTICA EM ESPINOSA}

\subsection{SOBRE A LIBERDADE}

Inicialmente, conforme explica Adriana Belmonte Moreira ${ }^{78}$, há necessidade de afirmar-se que, para Espinosa, o verdadeiro sentido da liberdade humana está essencialmente ligado à potência da razão, ou seja, à força ou poder que o intelecto dispõe para submeter os afetos ou paixões humanas ao seu tirocínio. $O$ sentido da liberdade humana não deve ser atribuído à nossa vontade, já que não possuímos uma vontade livre ou absoluta. E mesmo quanto ao poder da razão, este deve ser visto, antes, como moderatio, isto é, um poder de estabelecer uma justa medida no julgamento dos conflitos possíveis entre as várias paixões que se nos apresentam.

Para Espinosa, o único ser verdadeiramente livre é Deus, pois se considera livre apenas o que existe pela mera necessidade de sua natureza, e não é condicionado por nenhuma causa anterior à sua existência, ao contrário de todos os outros seres. Assim, na própria definição do filósofo:

“(...) digo ser livre o que existe e age exclusivamente pela necessidade da sua natureza, e coagido o que por algo (ab alio) é determinado a existir de certa e determinada maneira. (...) Deus, por exemplo, existe livremente embora exista necessariamente, porque existe pela única necessidade de sua natureza .Note bem, eu não faço consistir a liberdade numa decisão livre, mas na livre necessidade". ${ }^{79}$

A rigor, exceto Deus, nenhum outro ser detém uma vontade livre e isenta de precondicionamento. A necessidade de sobrevivência, de autopreservação, o conatus esse preservandi, é que determina no fundo os mais variados comportamentos. "Todas as coisas, quanto delas depende, esforçam-se em persistir em suas próprias naturezas, e o esforço com o qual uma coisa procura

\footnotetext{
78 MOREIRA, Adriana Belmonte. Potência da Razão e Liberdade Humana: uma análise do prefácio, axiomas e das quatro primeiras proposições da parte $\mathrm{V}$ da Ética. IN: Cadernos Espinosanos XXII, pág. 141/142. Disponível em: http://www.ffich.usp.br/df/espinosanos/26 html. Acesso em 05 nov. 2014.

${ }^{79}$ ESPINOSA. ÉTICA, op. cit. p. 84.
} 
persistir em seu próprio ser, nada mais é do que a verdadeira essência daquela coisa". ${ }^{80}$

Assim, enquanto Deus detém uma liberdade absoluta, já que sua essência pressupõe necessariamente sua existência, todas as demais coisas existentes na Natureza, inclusive o ser humano, apenas possuem uma liberdade relativa, já que sua existência depende causas anteriores e extrínsecas. A essência desses seres singulares não se realiza automaticamente, necessitando de fatores, tanto anteriores quanto exógenos, para se completar cabalmente.

Essa liberdade relativa de todas as coisas criadas é realizada quando elas conseguem sobreviver cumprindo plenamente sua essência. Assim, exemplificando, uma ave será relativamente livre para poder voar, acasalar-se e gerar sua prole, construir seus ninhos em árvores ou penhascos, mas não será absolutamente livre para poder pousar no solo, e ficar totalmente a salvo de predadores.

Uma videira será relativamente livre se, plantada em terra fértil, banhada por generosa luz solar e for bem cuidada, puder dar farta uva, da qual aprendemos a fazer excelente vinho. Uma figueira será relativamente livre se, nas mesmas condições, puder dar doces figos em abundância. Mas essa mesma videira e essa mesma figueira não são absolutamente livres, já que não são completamente livres para poder dar frutos diferentes daqueles que dão, uma vez que não é da sua natureza produzi-los.

O ser humano será relativamente livre quando puder realizar plenamente, sem constrangimentos externos, físicos, morais, sociais ou políticos, as potencialidades inerentes à sua natureza, as quais são distintas de indivíduo para indivíduo. Assim, será tanto mais livre quem, presentes circunstâncias materiais e sociais favoráveis, ou, pelo menos, ausentes fatores externos constrangedores ou limitadores, possa desenvolver relativamente em liberdade seus dotes naturais. Mas não será completamente livre para alcançar tudo o que sua imaginação e suas paixões almejam.

${ }^{80}$ ESPINOSA. ÉTICA, op. cit. p. 188 - 189. 
Destarte, segundo Marilena Chaui ${ }^{81}$, Espinosa sublinha que é livre quem age por necessidade de sua natureza, e não por mera causalidade de sua vontade, pois liberdade não é a total ausência de causalidade, mas a presença de causa necessária interna e eficiente que conduz à realização da essência singular de cada indivíduo. E a autora prossegue afirmando que o ser humano não se pode considerar livre por possuir livre arbítrio que lhe permita escolher entre finalidades diversas, mas por possuir uma potência natural, corporal e intelectual, que lhe permita agir em conformidade com sua natureza. E essa liberdade será tanto maior quanto mais vivermos sem estar submetidos a causas externas, estranhas à nossa natureza. Já a escravidão, ao contrário, será tanto maior quanto mais dependermos de causas estranhas a nos mesmos, e não nos determinarmos por nossas reais necessidades.

A liberdade humana não é, pois, absoluta, nem dotada de livre arbítrio, contrariamente ao pensamento clássico que atribuía ao ser humano pleno livre arbítrio, já que poderia agir segundo fins determinados e previamente escolhidos.

Mas fins e finalidade realmente não existem. Segundo Marilena Chaui ${ }^{82}$, Espinosa demonstra que a finalidade é mera ignorância das verdadeiras e eficientes causas de nossos apetites e desejos, os quais, pela nossa imaginação, projetamos na Natureza, e desta em Deus. Não conhecendo as reais causas da origem das coisas, e da causalidade necessária em toda a Natureza, atribuímos uma finalidade àquilo que nos é apenas útil. Ou seja, a utilidade transformada em finalidade. E o paradoxo é que esta mesma suposta finalidade teria o condão de destruir a liberdade, tanto divina quanto humana, pois submeteria as ações de Deus e do homem ao constrangimento da persecução de certos e determinados fins. Ou seja, se existem fins a ser atingidos, nem Deus poderia ser considerado livre, pois teria de agir rigorosamente para alcançar esses fins, e consequentemente não teria liberdade para se autodeterminar.

E essa mesma utilidade das coisas é que nos leva a rotulá-las de boas ou más, conforme a conveniência. Provêm daí as noções de bem e mal, já que estes

81 CHAUI, Marilena de Souza, op. cit. p. 81.

82 Ibid., p. 82. 
atributos não existem absolutamente na Natureza. Como bem explica Antonio Negri83, "El mundo solo és ético em la medida em que y porque lo vivimos".

Como diz Espinosa ${ }^{84}$, não desejamos as coisas porque são boas em si mesmas, ou porque nos dão um prazer objetivo, mas elas são boas ou nos dão prazer porque somos nós que as desejamos. Elas não nos atraem por qualidades objetivas a elas pertinentes, nós é que somos atraídos por elas subjetivamente, pois somos condicionados a desejá-las independentemente de seu valor. Ou como enfatiza Homero Santiago ${ }^{85}$, não desejamos algo porque é útil, mas algo nos surge como útil exatamente porque o desejamos. E ao querer, uma pessoa normalmente sabe o que quer, mas quase nunca sabe porque quer o que quer.

Segundo Hadi Rizk ${ }^{86}$, da utilidade de uma coisa para nós, projetamos nosso desejo pela coisa como uma solicitação, pelo objeto, do nosso desejo, numa finalidade que atrai nossa vontade, numa completa inversão da realidade. Dessa ilusão da existência de uma finalidade em toda a Natureza, projetamo-la para Deus que, assim, organiza todas as coisas que existem só em prol do homem. De acordo com Antonio Negri87, não é finalidade o fato de a alma sempre se esforçar na visualização do que pode aumentar ou favorecer a potência do corpo. Isto não é mais do que uma afirmação do próprio ser, da sua própria potência.

Essa ilusão da existência em toda a Natureza de determinados fins, fruto da inversão do critério da utilidade pelo da finalidade, faz-nos imaginar donos de uma vontade livre para escolher entre várias opções à vista.

Mas, como explica Espinosa ${ }^{88}$, na mente não existe vontade absolutamente livre, pois ela é determinada a querer algo por uma causa que também é determinada por outra, e esta também por outra, e assim até ao infinito. "Os homens pensam que são livres porque têm consciência de seus próprios desejos, mas ignoram as causas pelas quais esse desejo foi determinado." 89

\footnotetext{
83 NEGRI, Antonio, op. cit. p. 32.

84 ESPINOSA. ÉTICA, op. cit. p. 190.

85 SANTIAGO, Homero. ENTRE SERVIDÃO E LIBERDADE. IN: Cadernos Espinosanos XXVI, p. 14. Disponível em: http://www.ffich.usp.br/df/espinosanos/26 html . Acesso em 05 nov. 2014.

${ }^{86}$ RIZK, Hadi, op. cit. p. 116.

87 NEGRI, Antonio, op. cit., p, 34.

88 ESPINOSA. ÉTICA, op. cit. p. 174.

89 ESPINOSA. Carta LVIII.
} 
Espinosa ${ }^{90}$ faz uma comparação interessante daquilo que seria a vontade comumente tida por livre e absoluta. Seria igual à consciência que, porventura, uma pedra pudesse ter ao se projetar em queda livre no chão, imaginando ser senhora absoluta de sua trajetória, espaço e horário da queda, pois ignorando as leis da gravidade. Assim também nós que, ignorando praticamente todas as leis da natureza, pretendemos estar no comando de nossas ações.

O que denominamos comumente por vontade, deveria, antes, ser chamado de apetite, que nada mais é do que o conatus do corpo. Esse apetite, esse instinto de preservação, uma vez iluminado pela consciência, redundaria no desejo, que nada mais seria do que o correspondente conatus da alma. Para Espinosa ${ }^{91}$, "o desejo (Cupiditas) é a própria essência do homem".

Como realça Homero Santiago ${ }^{92}$, somos seres ignorantes e desejantes. Não somos cônscios da maior parte das causas de nossos desejos. Junto à zona da consciência, há toda uma região de sombras e penumbra, da qual brota toda uma gama de apetites e impulsos, os quais jamais aflorarão à luz da consciência.

Assim, somos determinados pela necessidade de sobrevivência, a qual fundamentaria nossos instintos e apetites, o conatus do corpo, e estes, iluminados pela consciência, acenderiam nossos desejos, o conatus da alma, acionando pensamento e ação para satisfazê-los. Dessa forma, sempre por trás de qualquer impulso ou apetite, seja ele consciente ou não, aflora o conatus esse preservandi, o inato esforço de autopreservação.

Mas, como o próprio filósofo diz ${ }^{93}$, exatamente na medida em que conseguimos ser a causa adequada de nossas próprias ações, e se o fizermos sem 0 constrangimento de causas exteriores, nessa exata medida, portanto, poderemos nos considerar livres. E como causa adequada deverá se entender, em primeiro lugar, a exata correspondência entre aquilo que queremos e pelo qual agimos, com o que deveríamos querer e agir segundo a nossa razão, na execução fiel do cumprimento da nossa essência e segundo as leis da natureza; e em segundo lugar, sermos determinados exclusivamente por causas internas, ou seja,

\footnotetext{
90 ESPINOSA. CARTA LVIII.

91 ESPINOSA, op. cit. p. 219.

92 SANTIAGO, Homero, op. cit. p. 14.

93 ESPINOSA, op. cit. p. 181.
} 
determinarmo-nos exclusivamente por nós mesmos e não sermos condicionados por causas exteriores a nós, com a ilusão de uma finalidade nelas explícita que tem de ser buscada a qualquer preço. Não podemos nos comportar como mariposas ao redor da luz, presas por ofuscamento. Se houver qualquer luz não será para prender-nos, mas para iluminar-nos os passos rumo ao caminho da vida.

Ou seja, se agirmos rigorosamente de acordo com as leis da natureza, buscando o que nos é realmente útil à autopreservação, cumprindo o itinerário imanente a nossas essências particulares, aí sim, poderemos nos considerar livres. Este é o quantum, o limite da nossa liberdade e de nosso suposto livre arbítrio.

Determinarmo-nos, sempre, seguindo caminhos iluminados pela razão na busca da realização de nossa essência, a qual nada mais é do que procurar a manutenção daquilo que somos, pelo maior tempo possível e longe, tanto quanto formos capazes, das vicissitudes exógenas, de tudo que possa embaraçar esse objetivo. Como já antes afirmado, todos nos gabamos de ser livres, porque, na verdade, ignoramos a real causa de nossos desejos.

Ser livre é, na verdade, ter uma consciência iluminada sobre nossas reais necessidades, aquelas realmente importantes para a nossa existência, e nos determinarmos fielmente de acordo com elas. Ao contrário, a ignorância dessas reais causas, ou o fingimento de que podemos nos determinar por meros caprichos aleatórios da nossa parte, não é apanágio de qualquer liberdade.

A ideia de aleatório e de contingente não é característica real do mundo, mas apenas uma deficiência de nosso intelecto. Com efeito, como explica Marilena Chauí $^{94}$, a ideia do possível e do contingente estão arraigadas ao conceito da temporalidade e não da eternidade. De fato, como nesta não existe quando, nem antes nem depois, "segue-se que Deus não poderia existir antes de seus decretos, de maneira a poder decidir outra coisa". E como há absoluta identidade entre a essência e a existência divinas, segue-se que tudo é necessário e não contingente.

${ }^{94}$ CHAUÍ, Marilena, op. cit. p. 432. 
Como salienta a mesma autora ${ }^{95}$, chamamos de possível aquilo cuja real causa nos é desconhecida, e de contingente aquilo do qual desconhecemos sua natureza, sua verdadeira essência. Segundo Roger Scruton ${ }^{96}$, para Espinosa, ao aumento de nossa percepção das coisas como absolutamente necessárias, corresponderia um exato aumento de nossa liberdade, pois "liberdade não é liberdade da necessidade, mas antes a consciência da necessidade". Assim, numa prova matemática, por exemplo, nosso espírito é totalmente determinado pela necessidade lógica, e se liberdade pudesse ser liberdade da necessidade da lógica, de suas regras, essa liberdade não serviria para nada.

O homem livre, portanto, é exatamente aquele que, tendo plena consciência de suas necessidades, assim se determina para cumpri-las. Mas não é livre quem segue apenas determinado por causas externas, respondendo ao apelo de imaginárias finalidades, imaginando estar no comando de suas ações, pensando agir por mero capricho, pois, como vimos anteriormente, para Espinosa não existem caprichos na natureza.

E esta noção da liberdade humana, como consciência da necessidade, Espinosa a identifica com a virtude, virtude essa da realização plena de sua potência:

"Por virtude e força quero dizer a mesma coisa (...) quanto mais um homem pode preservar o seu ser e buscar o que lhe é útil, mais é a sua virtude. E inversamente, quanto mais cada um omite conservar o que the é útil, isto é, conservar o seu ser, tanto mais é impotente" 97 .

Portanto, o homem só agirá por virtude quando se determinar por meio de causas adequadas: "O homem, enquanto é determinado a fazer alguma coisa pelo fato de ter ideias inadequadas, não se pode dizer absolutamente que age por virtude; mas, sim, somente enquanto é determinado pelo fato de ter um conhecimento"98. A virtude, pois, pressupõe conhecimento, conhecimento do conatus, esse esforço para a manutenção da vida, e a felicidade consistiria nessa realização.

O ser humano prudente e sábio aprende com a experiência do cotidiano, seus sucessos e revezes, e assim é levado a determinar-se com um pouco de liberdade, na medida em que transforma a experiência passada e vivida em

\footnotetext{
${ }^{95}$ CHAUÍ, Marilena, op. cit. p. 404.

${ }^{96}$ SCRUTON, Roger, op. cit. p. 96.

${ }^{97}$ ESPINOSA, ÉTICA, op. cit. p. 246.

98 Ibid., p. 247.
} 
previsão, e consegue se pautar por esta. Consegue, assim, antever o seu destino e deixar de ser apenas escravo da ignorância.

A servidão humana seria a completa ignorância das causas pelas quais nos determinamos, guiados e condicionados por objetos exteriores nos quais enxergamos bens e fins em si mesmos, e a libertação seria nossa determinação por causas inerentes à nossa natureza, iluminados pela razão e pelo conhecimento, guiando-nos ao caminho da sobrevivência e à plena realização de nossas potências.

Como salienta Chauí ${ }^{99}$, a servidão tem fundamento na nossa dependência absoluta de potências alheias, forças externas, gerando uma passividade que nos aliena, já que deixamos de depender de nossa natureza. No mesmo diapasão, segundo Homero Santiago ${ }^{100}$, tanto a liberdade quanto a servidão têm origem na nossa busca do útil. "Ex natura mostra libertas \& servitudo". O que vai definir se alcançamos uma ou outra é a qualidade do nosso desejo: se este for na direção do que nos é verdadeiramente útil, temos a liberdade; caso vá na direção do objeto errado, teremos a alienação ou servidão.

Quanto mais conhecimento, pois, maior a liberdade possível. Então, por meio do conhecimento, sabemos o que nos é útil ou não e, assim, poderemos nos determinar livremente.

Embora não possamos libertar-nos de todo o condicionamento, já que existe uma causalidade necessária na natureza, conhecendo bem as suas leis poderemos tirar alguma utilidade desse aprendizado. Seremos livres na medida desse conhecimento.

Sócrates já pregava isso ao longo de sua vida, muito embora a ênfase de Sócrates recaísse no escopo moral, no aperfeiçoamento da alma, enquanto Espinosa embasava a necessidade de conhecimento num naturalismo extremado, para aferição da utilidade ou não de determinados comportamentos. Para ele, o conhecimento, como fonte de percepção da utilidade de nossas ações,

${ }^{99}$ CHAUÍ, Marilena. A posição do agente da liberdade na ética V. IN: Cadernos Espinosanos, XXII, p. 21. Disponível em: http://www.ffich.usp.br/df/espinosanos/26 html. Acesso em 05 nov. 2014.

100 SANTIAGO, Homero, op. cit. p.16. 
acrescentava uma maior liberdade humana, já que aportava um maior acréscimo à nossa potência natural.

Esta potência natural aumenta proporcionalmente à nossa independência de fatores externos para realizarmos nossas atividades. E para tal é necessário o acúmulo de informações, seja com base na experiência, seja com base na pura racionalidade. À medida que compreendamos que a determinadas causas sucedem determinados efeitos, por intermédio de nossa potência talvez possamos eleger umas e excluir outras.

Mas a nossa potência é limitada, e poderá entrar em choque com outras potências singulares, as quais disputam os mesmos meios de sobrevivência. $E$ mais uma vez, através da plena percepção da realidade, podemos chegar à conclusão de que nos é útil a colaboração com outros seres semelhantes, de modo a aumentar a nossa potência de agir.

Deste modo, nossa liberdade pode ser incrementada na medida em que nos unamos com outros seres humanos, em estreita cooperação e união de esforços. Pois, de acordo com Espinosa ${ }^{101}$, sempre que duas coisas ostentam a mesma natureza, elas poderão ser mutuamente benéficas, e os seres humanos concordam em sua natureza, quando são conduzidos pela razão, pelo conhecimento. Assim, a união dos seres humanos com base no poder racional, aumenta a sua potência de agir e, consequentemente, o seu quantum de liberdade também.

Como salienta Don Garrett ${ }^{102}$, o homem livre, agindo pelos ditames de seu lado racional, busca incessantemente a cooperação com outros homens, e para isso é necessário sempre a presença da boa fé. $E$ a ausência desta poderá ser atribuída à falta de liberdade de uma pessoa, ou seja, à sua incapacidade de se conduzir conforme à razão, já que esta induz os seres humanos à cooperação e não à perfídia ou à beligerância.

101 ESPINOSA. ÉTICA, op. cit. p. 250 - 252.

102 GARRETT, Don. Teoria ética de Spinoza. In: GARRETT, Don. SPINOZA, op. cit. p. 367. 
No entanto, há certas circunstâncias em que a uma pessoa poderá ser permitido conduzir-se dolosamente, contrariando a máxima de Espinosa, segundo a qual o "homem livre não age nunca com fraude, mas sempre de boa fé". ${ }^{103}$

E o próprio Espinosa ${ }^{104}$, em demonstração de sua preposição, abre uma exceção para o caso de risco iminente de morte, no qual seria permitido ao homem usar de perfídia, dolo, para conservar a vida, agindo, assim, de acordo com sua natureza, apoiado pela razão que o obriga à autopreservação.

E isto em virtude de o ser humano ter um poder limitado sobre a natureza, ser parte dela, e, eventualmente, poder enfrentar uma situação em que teria de usar de má fé, de deslealdade, para sobreviver. Seria a conhecida situação de um naufrágio, em que a sobrevivência de uns poderá excluir a de outros. Nessa situação, o ser humano, pelo fato de optar pela sua sobrevivência, não deixará de ser livre por ter tomado uma atitude dolosa. A sua natureza interpela-o mesmo para fazer exatamente isso.

E Don Garrett ${ }^{105}$, interpretando essa passagem de Espinosa, explica que o que a razão não poderia, de maneira alguma, era recomendar o dolo em quaisquer condições, porque a razão, em princípio, sempre recomenda que os seres humanos juntem suas forças, em cooperação e com lealdade. E os homens realmente dotados de virtude, conhecimento e, por consequência, de liberdade, sempre buscariam meios diferentes do dolo para ter de evitar o dilema de escolher entre ele e a própria morte.

Mas, na realidade, não há homem tão poderoso que não se possa defrontar, em algum momento de sua vida, com uma situação concreta em que tenha de decidir-se pelo uso do dolo ou enfrentar a morte. Seria o caso da já citada situação de um naufrágio. Daí, segundo o mesmo autor, sermos levados a concluir que Espinosa, em outro contexto, afirma que algo pode ser bom, ainda que não seja virtuoso. De maneira geral ele sustenta que um mal menor, pode ser, na realidade, um bem. Para o filósofo, portanto, quando a única alternativa for

${ }^{103}$ ESPINOSA. ÉTICA, op. cit. p. 274.

104 Ibid.

105 GARRETT, Don, op. cit. p. 368. 
a morte, o dolo poder-se-á considerar como um mal menor e, por isso mesmo, um bem, ainda que um homem livre procure não agir dessa maneira.

Don Garrett ${ }^{106}$ chama de liberdade assimétrica, usando uma expressão batizada por Susan Wolf numa alusão a Kant em outro contexto, a atribuição de responsabilidade à liberdade de apenas praticar o bem. Contrariando os pensadores deterministas, segundo os quais liberdade e responsabilidade moral tendem a andar juntas, ou seja, se o homem dispõe de livre arbítrio é responsável por suas ações, caso contrário não é responsável, Espinosa pensava diferente.

Segundo o autor atrás mencionado ${ }^{107}$, a concepção de liberdade espinosana tem um viés assimétrico, pelo fato de o filósofo apenas considerar que o homem só age livremente quando pratica o bem. Quando praticamos o mal não somos livres, pois não nos conduzimos por meio de ideias adequadas, e, por isso mesmo, não seríamos responsáveis por nossas faltas. Praticá-las-íamos movidos pelas paixões e impulsos inconscientes, sem o freio do comportamento racional. De onde, a prática de faltas pelo ser humano não poderia gerar nunca responsabilidade moral.

Mas, frise-se bem, isso não quer dizer que não haja nem deva haver responsabilidade social. Esta é gerada pela necessidade de cooperação na vida em sociedade, e o Estado tem o dever de punir para preservar a paz e, assim, preservar a conservação de todos, que é a meta da vida em sociedade. Mas o filósofo adverte que a ação estatal nunca deverá ser fundada em ressentimento ou por retribuição: “(...) Mas deve-se notar que, quando o poder soberano, no desejo que tem de proteger a paz, pune um cidadão que fez alguma injúria a um outro, não digo que ele se indigna contra o cidadão, porque não é levado pelo ódio a perder o cidadão, mas pune-o movido pela piedade". ${ }^{108}$

Vê-se, cristalinamente, que para Espinosa, a sanção estatal para os delitos e faltas cometidas não seria consequência de uma teoria da retribuição, pela qual se paga o mal com o mal, tal como queriam Kant e os iluministas, mas apenas por um fundado desejo de autoproteção do próprio autor do delito e da sociedade.

106 GARRETT, Don, op. cit. p. 378.
107 Ibid., p. 378.
108 ESPINOSA. ÉTICA, op. cit. p. 263. 
Não se retribui o mal com a aplicação de uma pena, de um castigo, pelo fato de o ser humano não ter domínio absoluto de suas ações, como de resto, tudo na natureza. Comete o mal porque não é livre nesse momento. A pena, a sanção, só deve ser exercida como medida de contenção, de proteção, e para isso deve-se buscar sempre a razoabilidade.

Dispomos, portanto, de uma verdadeira liberdade quando praticamos o bem, pois estaremos agindo nesse momento guiados pelo nosso entendimento, iluminado por ideias apropriadas à nossa natureza racional. A responsabilidade moral pressupõe essa liberdade de agir racionalmente, mas quando pratica o mal o homem não deve ser responsabilizado, pois não agiu de acordo com sua natureza racional.

Na verdade, se um indivíduo rouba ou mata um seu semelhante, ele não estará agindo racionalmente, pois a impunidade não é certeza e a sociedade sempre procurará a incolumidade de qualquer agressão. Além disso, como reiteradamente afirmado por Espinosa, nada é mais útil para um ser humano do que outro ser humano. Este, portanto, no cometimento da falta ou delito, agiria sob o domínio de suas paixões e impulsos, não sob o império da razão. Por isso mesmo, não poderá ser responsabilizado moralmente, embora possa e deva ser responsabilizado socialmente, já que inserido numa sociedade regida por normas que buscam preservá-la.

Concluindo este capítulo, é deveras importante trazer aqui a posição um tanto divergente de Antonio Negri ${ }^{109} \mathrm{em}$ relação a todos os pensadores antes mencionados, no tocante à relação entre liberdade e necessidade. Segundo este autor, a liberdade espinosiana tem de ser encarada, antes, como verdadeira constituinte do real. A liberdade interage continuamente com a necessidade, as duas se condicionam, traduzindo-se num horizonte atual de inovação do mundo. O real mesmo, a imanência absoluta, se apresenta continuamente reformado, formando-se e constituindo-se eticamente. Segundo sua interpretação, a liberdade se apresenta, na verdade, como uma ferramenta para reformar o mundo, capaz até de reinventar o ser: como diria o sábio grego, dai-me uma alavanca e levantarei o mundo, ou, pelo menos, dai-me um bastão e serei capaz

109 NEGRI, Antonio, op. cit. p. 157 - 158. 
de afastar o medo hobbesiano que a todos tolhia. Com a ferramenta da liberdade em mãos, seremos capazes de construir uma prótese de corpo e alma que force $o$ mundo a passar da carência à satisfação, ou pelo menos a construirmos uma liberdade de ação com a ferramenta do racional e do metafísico.

Em síntese, os seres humanos, como de resto todas as coisas existentes na natureza criada, não dispõem de uma liberdade absoluta que thes consagre um total livre arbítrio para poder decidir cabalmente em qualquer circunstância sob a sua livre vontade, já que esta livre vontade não existe. Dispõem, sim, de uma liberdade apenas relativa, a qual será tanto maior quanto mais dispuserem de pleno conhecimento sobre a causalidade imanente e necessária existente na Natureza. E essa liberdade relativa é o quanto basta ao pleno aperfeiçoamento de suas potências singulares de que são investidos, para poder sobreviver e realizar suas essências particulares. Por isso o ser humano é mais livre que os demais animais, já que dispõe de uma razão, não de uma vontade, que the poderá mostrar o caminho mais seguro para uma existência mais duradoura. Quanto à responsabilidade, devido à não existência de um pleno livre arbítrio, não há responsabilidade moral, já que moral e finalidade não são inerentes à Natureza, mas criação do próprio ser humano. Mas esta exclusão da responsabilidade moral não implica na ausência da responsabilidade social, já que esta é condição indispensável à existência da própria sociedade. 


\subsection{ORIGEM DO ESTADO}

Desta noção de liberdade, como sendo a nossa capacidade de agirmos livremente quando nossos comportamentos forem ditados por um entendimento racional, evoluímos para o estabelecimento do Estado e da sociedade organizada. E quando, e como, terá acontecido a mudança do estado natural para o estabelecimento das instituições sociais? A concepção moderna de poder e soberania assentou-se basicamente em algumas teorias diferentes, a seguir explicitadas.

Uma corrente filosófica e política procurou fundamentar o poder estatal na origem divina, tal como preceituado por Bossuet e outros teóricos, segundo os quais o poder do soberano provinha diretamente de Deus, robustecendo, assim, o poder absolutista dos monarcas. A Ordem Profética, como lhe chamava Espinosa, e que será objeto de um explanação mais aprofundada a seguir, constituía, ou constitui ainda, uma antecipação dessa teoria. Para esta corrente filosófica, segundo Marilena Chauí ${ }^{110}$, duas tendências se revelariam: numa primeira, ou o poder viria diretamente de Deus para o governante, ou este o receberia através da mediação daqueles que detinham o jus circa sacra (por ex., o papa ou os concílios); numa segunda variação, o poder nasceria da implantação das leis divinas na alma humana, e o povo, enquanto Voz de Deus, elegeria o soberano.

Uma outra corrente, mais razoável, derivava o poder estatal do direito natural, aqui encarado em sua concepção tradicional, não espinosiano, com a implantação inata na razão humana de regras universais e eternas, válidas para todos os tempos e lugares, daí derivando um poder e soberania naturais.

E uma derivação desta última teoria fundamentava a soberania do estabelecimento de um pacto, de um contrato social, tal como preconizado por Hobbes, e mais tarde por Rousseau, ainda que com consequências distintas.

De acordo com Alysson Leandro Mascaro ${ }^{111}$, enquanto para Hobbes o Estado, após estabelecido, era uma instituição superior e distinta dos próprios indivíduos

110 CHAUÍ, Marilena. op. cit. p. 97 - 98.

111 MASCARO, Alysson Leandro, op. cit. p. 151 - 152. 
que o criaram, para Espinosa e Rousseau, a instituição do Estado não poderia ser pensada como distinta e estranha aos seus súditos criadores por meio de um pacto. Por outro lado, Bobbio ${ }^{112}$ afirma:

"O que, quando muito, distingue Spinoza de Hobbes é que, enquanto para Hobbes o pacto de união pode ser configurado como um contrato em favor de um terceiro (como diria um jurista), para Spinoza - que nisso antecipa claramente Rousseau e o conceito tipicamente rousseauniano da liberdade política como autonomia - o próprio pacto de união prevê a transferência do poder natural de cada um para a coletividade da qual cada um é parte".

Mas, contrariamente a esta linha de raciocínio, Antonio Negri ${ }^{113}$ afirma que a vontade de todos de Espinosa não é a vontade geral de Rousseau, porque aquela pressupõe como fundamento a liberdade plena de cada um, o respeito a todas as consciências, e, enfim, a fundação de uma tolerância universal que seja capaz de acomodar todas as divergências porventura existentes. A vontade geral de Rousseau não é dinâmica, é estática, não é continuamente negociada, é, antes, estabelecida. Pois, de acordo com o próprio pensamento de Espinosa ${ }^{114}$ :

\begin{abstract}
"Em democracia, com efeito, ninguém transfere o seu direito natural para outrem a ponto de estre nunca mais precisar de o consultar; transfere-o, sim, para a maioria do todo social, de que ele próprio faz parte e, nessa medida, todos continuam iguais, tal como aconteceria anteriormente no estado de natureza. (...)

Porém, apesar de concebermos assim o direito e o poder do Estado de maneira bastante ampla, jamais ele será tão grande que aqueles que o detêm possam fazer absolutamente tudo o que quiserem, conforme creio já ter mostrado com suficiente clareza".
\end{abstract}

Esta teoria do contrato social, segundo Negri ${ }^{115}$, formou-se hegemonicamente entre os autores mais conhecidos, entre muitos dos quais pode-se citar Jellinek, Duguit, Del Vecchio, Carl Friedrich, Bobbio. Para essa corrente hegemônica, essa teoria não conferia ao contrato social uma natureza sociológica, mas exclusivamente jurídica, ou seja, não seria baseada na associação factual do ser humano para a constituição de uma sociedade civil, mas como legitimação formal da constituição da sociedade política pela transferência do poder da sociedade civil ao Estado.

Para Antonio Negri, a teoria do contrato social não passava de uma ficção sociojurídica que serviria, unicamente, para legitimar a transferência desse

112 BOBBIO, Norberto. Sociedade e estado na filosofia política moderna, apud MASCARO,

Alysson Leandro, op. cit. p. 151.

113 NEGRI, Antonio, op. cit. pág. 76 - 77.

114 ESPINOSA. Tratado teológico-político, apud MASCARO, Alysson Leandro, op. cit. p. 151.

115 NEGRI, Antonio, op. cit. p. 59. 
mesmo poder e, consequentemente, fundamentar a base jurídica do Estado. E isso é atestado por autores do porte de Kelsen, Bobbio, Luhmann e Rawls.

Segundo o mesmo autor ${ }^{116}$, no universo espinosiano reconhece-se a existência de duas correntes políticas que não aceitam o fundamento jurídico e político do contrato social: uma, ligada a um radicalismo republicano da cultura humanista e renascentista, representada por Maquiavel; e outra, ligada a um radicalismo democrático do protestantismo, tendo como representante Althusius. Este, ainda que aceite o contrato, rejeita expressamente a ideia de alienação do poder, e afirma que o contrato é inseparável da associação dos indivíduos. O verdadeiro sujeito da soberania seria o populus universus in corpus unum symbioticum ex pluribus minoribus consociationibus consociatus, (Althusius, 1603, Prefácio) ${ }^{117}$, ou seja, todo o povo unido num só corpo a partir da aglutinação de associações menores. Em ambas essa correntes, segundo o autor, campeava uma ideia do político de fundo sociológico baseado nas práticas e nas especificidades das múltiplas potência singulares.

Em Maquiavel e Althusius o realismo político não é exatamente um relativismo de valores, mas uma adesão à verdade estabelecida pela concretude social, numa visão materialista e não jurídica. Assim, o mesmo autor conclui dizendo que a teoria do contrato social é, no fundo, a teoria por excelência do estado absolutista. Isso, ao passo que a rejeição dessa teoria, ou a não aceitação da transferência do poder como no caso das correntes políticas afiliadas ao espinosianismo, representam tradições republicanas e democráticas, alheias e estranhas a toda a prática representativa e alienação. Ao absolutismo estatal, afirmado pela teoria do contrato social, se opõe, pois, a teoria que rejeita qualquer trespasse do poder, reafirmando o social como valor absoluto, identificado ao valor metafísico da verdade expressa pela ação pragmática.

Pelo contrato social de Hobbes, os indivíduos abriam voluntariamente mão de seus direitos, em troca de paz e segurança, e os confiavam à guarda do soberano, o qual passava a deter sobre os mesmos, como se viria na prática, poder de vida ou morte. Mas a paz não pode ser o fim último e único da criação

\footnotetext{
116 NEGRI, Antonio, op. cit. pág. 61.

117 lbid., p. 62.
} 
do Estado, tal como pretendia Hobbes, com a amputação da liberdade e da consciência da civitas. A insistência na busca da paz a qualquer preço, como sendo o principal móbil da criação do Estado, e na origem de um hipotético contrato social hobbesiano, pressupõe um estado total e permanente de beligerância, apto apenas a legitimar governos déspotas. E os homens não são natural e necessariamente maus como queria Hobbes, apesar de também não serem naturalmente bons como pretendia Rousseau.

A paz tem de ser vista como mera consequência da criação da civitas, ainda que dirigida por um monarca. Organizada a civitas, mas mantendo-se a liberdade natural dos cidadãos, deixando que exercessem livremente sua potência natural, floresceria naturalmente a paz como mera consequência. Esta não poderia, como único objetivo a ser perseguido, emascular a vontade e a razão dos cidadãos.

Enfim, na origem da vida social dos indivíduos não é o mero desejo de segurança, do medo da morte, o único ou principal móbil a constituir o poder organizado estatal, mas, sim, a busca de multiplicação da capacidade humana, de suas potências naturais, pela cooperação e divisão de tarefas. A paz, como resultado natural dessa cooperação, é apenas um dos efeitos naturais.

A busca da segurança a qualquer custo, tal como preconizado por Hobbes, levaria aos regimes absolutistas e déspotas, tal como aconteceu e vem acontecendo ao longo da história. E esses regimes, embora possam parecer estáveis e pacíficos, não se constituíram em vantagens para os cidadãos, já que estes se veriam privados de exercer suas potências naturais e assim se desenvolver.

$E$, note-se, não é necessário estar confinado em prisões, posto a ferros, para o ser humano se ver privado de sua natureza e viver sob o império do medo. Nesta linha de raciocínio, Espinosa afirma:

"Se numa cidade os súditos não tomam as armas porque estão dominados pelo terror, deve-se dizer, não que aí reina a paz, mas, antes, que a guerra aí não reina. A paz, com efeito, não é a simples ausência de guerra, é uma virtude que tem a sua origem na força da alma, pois que a obediência ( $\$ 19$ do capítulo II) é uma vontade constante de fazer o que, segundo o direito comum da cidade, deve ser feito. Uma cidade, é preciso dizê-lo ainda, em que a paz é efeito da inércia dos súditos 
conduzidos como um rebanho e formados unicamente na servidão, merece mais o nome de solidão que o de cidade". ${ }^{118}$

Deste modo, não se constituiria em verdadeira paz a existência de uma sociedade que, em prol de uma estéril estabilidade, vive sob o domínio do medo, já que este tenta se reproduzir numa escalada recíproca entre governantes e governados. Aqui, constata-se uma identidade com o pensamento de Maquiavel.

A organização política, então, na filosofia espinosiana, nasce da consciência de que a união de esforços, com corpo e alma envolvidos, já que os dois são inseparáveis e indivisíveis, aportando mais potência, aportará necessariamente mais liberdade, já que esta se traduz na nossa capacidade de agir racionalmente. E trazendo mais liberdade, e consequentemente mais potência de agir, não se pode inferir que o Estado limite ou tolha os direitos dos indivíduos, suas potências, tal como preconizado por Hobbes.

A necessidade de desenvolvimento e conservação da essência dos seres humanos leva-os a relacionar-se com outros, numa reciprocidade relacional de cooperação e interdependência. Deve haver, assim, na vida política, um regime de organização de relações que torne mais profícua a busca do que é útil à autopreservação, ampliando os direitos, e não restrigindo-os.

Como bem diz Hadi Rizk ${ }^{119}$, há dois grupos de impulsos que tecem as relações interindividuais: a piedade, que gera a benevolência, e a inveja, que promove a rivalidade e a ambição de dominação. Esses dois padrões de comportamento geram uma contradição, que se traduz numa mudança contínua e permanente da solidariedade em antagonismo e deste naquela. Por esse motivo é que não existem regimes políticos perenes, sendo todos precários, pois tais estados são determinados por relações de dominação e dependência, relações de poder que se alternam, numa dinâmica constante.

Haverá uma ruptura do regime quando sua utilidade desaparecer, pois, como diz Espinosa ${ }^{120}$, é "insensatez uma pessoa pedir a outra que jure para todo o sempre,

${ }^{118}$ ESPINOSA, TRATADO POLÍTICO, op. cit. p. 328.

119 RIZK, Hadi, op. cit. p. 126.

120 ESPINOSA. TRATADO TEOLÓGICO-POLÍTICO, apud BARRETO, Ana Cláudia Gama et alii (Org.). Spinoza \& Nietzsche: filósofos contra a tradição. Rio de Janeiro: Mauad X, 2011, p. 145. 
sem tentar, ao mesmo tempo, fazer com que a ruptura desse pacto traga ao que romper mais desvantagens que vantagens".

Como explica Alexandre Pinto Mendes ${ }^{121}$, o jusnaturalismo de Espinosa não é apto a gerar o instituto do contrato. Trata-se, antes, de uma teoria da hegemonia, de um jogo de forças e consensos a explicar a conservação, sempre tensa e delicada, dos vários regimes estatais.

Mas, de acordo Antonio Negri ${ }^{122}$, não há espaço na filosofia de Espinosa para qualquer jusnaturalismo. Pois, ainda que a literatura filosófica contemporânea, máxime Leo Strauss, pretenda ver um enfoque espinosiano tendente, não propriamente a uma secularização ou laicização da teoria religiosa, mas uma permanência jusnatural na temática religiosa, há que considerar, antes, no pensamento espinosiano uma verdadeira ruptura ateia e materialista contra toda a laicização e permanência teológica.

Para Espinosa, na interpretação de Hadi Rizk ${ }^{123}$, o desejo de dominação surge da ausência de poder e de potência, numa palavra, surge da fraqueza: quer-se dominar os outros para se alimentar da potência deles, que é igual ou maior. $E$ para isso tem de se dispor de um poder imaginário, o qual infunda temor e respeito aos semelhantes por uma suposta superioridade do outro.

Nessa esteira, Hadi Rizk ${ }^{124}$ diz que é indispensável o recurso ao imaginário, a fim de levar o outro a preferir um estado de servidão como se tratasse de liberdade. A submissão do dominado viria antes da dominação do senhor, pois aquele abriria mão previamente de sua potência, para entregá-la ao senhor, o qual assim ficaria mais forte, podendo dominar corpos e consciências. Se trataria, na verdade, de uma pura ficção, de uma representação falsa da realidade.

O mesmo autor antes citado aduz que é difícil, de outro modo, compreender-se como é que o sujeitado se torna cúmplice da sua servidão, encarando-a até como expressão de sua própria vontade, como sempre a tivesse querido.

A servidão perpetua-se, assim, por completa ignorância e pela crença messiânica de um regime visionário, abdicando da potência natural de que todo o indivíduo é dotado, a par de sua razão. Mas Marilena Chauí ${ }^{125}$ apresenta outras causas

\footnotetext{
121 MENDES, Alexandre Pinto. SPINOZA \& NIETZSCHE, op. cit. p. 145.

122 NEGRI, Antonio. op. cit. p. 57 - 58.

${ }^{123}$ RIZK, Hadi, op. cit. p. 127.

124 Ibid., p. 129.

125 CHAUÍ, Marilena, op. cit. p. 41.
} 
sociais para tentar explicar a origem da servidão humana. Haveria em nós uma cupiditas servil, um desejo supersticioso, imaginário e não racional, de servir e obedecer. Nossa imaginação projeta imagens delirantes sobre o outro, encarando-o como causa de nossa salvação - Deus, o Príncipe, a Tradição - ou da nossa perdição - o Diabo, Adão, a plebe. Como nos poderíamos imaginar agentes de nossa liberdade e felicidade, se não somos capazes de afastar a imagem de um Deus cheio de misericórdia que ama os justos, do bom Príncipe que só pratica a justiça? Como combateremos a infelicidade e a servidão, se as imaginamos produzidas pelo Imperador do mal, ou como castigo desse mesmo Deus misericordioso que nos atribui o pecado original de Adão? Para sermos agentes de nossa liberdade e afastarmos toda nossa servidão, teríamos de despir-nos de toda essa carga imaginária e fantasmagórica na qual nos criamos e nos desenvolvemos.

Mas essa voluntária servidão comum à maioria dos regimes antigos, essa submissão cega ao senhor, e que ainda perdura em muitos regimes atuais, embora com outros rótulos e eufemismos, não poderá ter sido a única causa da criação das instituições. Ela seria, sim, uma deturpação das sociedades embrionárias.

O ser humano teria intuído na associação com seus semelhantes o aumento de seu poder de autopreservação e satisfação de seus egoísmos. Nesta linha de pensamento, pondera Espinosa ${ }^{126}$ :

"Como no estado natural cada um é senhor de si próprio, enquanto pode defender-se
de forma a não sofrer a opressão de outrem, e porque, individualmente, o esforço de
auto defesa se torna ineficaz sempre que o direito natural humano for determinado
pelo poder de cada um, tal direito será na realidade inexistente, ou pelo menos só
terá uma existência puramente teórica, porquanto não há nenhum meio seguro de o
conservar. (...) Acrescentamos que sem mútua cooperação os homens nunca
poderão viver bem e cultivar a sua alma. Chegamos, portanto, a esta conclusão: que
o direito natural, no que respeita propriamente ao gênero humano, dificilmente se
pode conceber, a não ser quando os homens têm direitos comuns, terras que podem
habitar e cultivar em comum, quando podem vigiar a manutenção do seu poder,
proteger-se, combater qualquer violência e viver segundo uma vontade comum.
Efetivamente, quanto maior for o número dos que, reunindo-se, tenham formado um
corpo, tantos mais direitos usufruirão, também, em comum." E, ironicamente, Espinosa acrescenta: “(...) e se os escolásticos, pela razão de os homens em estado natural não poderem ser senhores de si mesmos, quiserem

${ }^{126}$ ESPINOSA. TRATADO POLÍTICO, op. cit. p. 318. 
chamar ao homem de animal sociável, nada tenho a objetar-Ihes". ${ }^{127}$ Isto, com certeza, é uma referência a Aristóteles, o qual rotulava o homem de "animal social ou político", pois o ser gregário, sociável, procura rigorosamente o convívio, estaria na sua natureza, seria da sua essência.

Mas o que para Espinosa seria da essência humana, não seria o chamado instinto gregário, tal como acontece com as formigas ou com as abelhas, em sua cega obediência a um comando genético imutável. E, sim, nosso egoísmo e individualismo, os quais, para serem plenamente satisfeitos, precisam da colaboração dos outros, com a intenção recíproca de obtenção de resultados mais úteis e prazerosos. Isso é que tornaria o homem social, gregário, e não necessariamente sua natureza. Se fôssemos naturalmente gregários, perseveraríamos numa ordem imutável de obediência cega a comandos preestabelecidos, prescindindo da criação de quaisquer instrumentos de guarda e vigilância, pois não tenderíamos à violação das regras estabelecidas.

E já vimos que os regimes políticos não são estáveis, muito menos perenes, sucedem-se numa alternância entre dominadores e dominados, senhores e servos, num jogo intrincado de ascensão e queda de poderes. Isso, porque os homens não são naturalmente gregários, previsíveis, mas procuram agir de acordo com seus impulsos de autopreservação.

E Espinosa ${ }^{128}$ assim comenta sobre o tema: "Portanto, para que os homens possam viver de acordo e ajudar-se uns aos outros, é necessário que renunciem ao seu direito natural e assegurem uns aos outros que nada farão que possa redundar em dano a outrem"

Embora os seres humanos estejam necessariamente sujeitos a paixões e outros impulsos, naturalmente mais guiados pela imaginação do que pela razão, se abstêm de causar danos a outrem só pelo temor de um prejuízo maior para eles.

O ser humano descobre, enfim, após muito sacrifício que, em seu estado natural, sua potência singular iria servir muito pouco à sua autopreservação e à satisfação de seus interesses vitais, já que outros seres semelhantes, iguais em capacidade

127 ESPINOSA. TRATADO POLÍTICO, op. cit. p. 318.

128 IDEM. ÉTICA, op. cit. p. 205. 
e habilidade, buscam os mesmos bens escassos e procuram satisfazer os mesmos desejos.

Só a aglutinação das muitas potências singulares, numa mais ampla potência coletiva, poderá resultar numa maior satisfação das necessidades e favorecer a sua conservação. Como diz Espinosa ${ }^{129}$ :

"Se duas pessoas concordam entre si e unem as suas forças, terão mais poder conjuntamente e, consequentemente, um direito superior sobre a natureza que cada uma delas não possui sozinha e, quanto mais numerosos forem os homens que tenham posto as suas forças em comum, mais direito terão eles todos".

E assim terão surgido as primeiras sociedades organizadas. Mas, ao contrário do pensamento de Hobbes, para quem o homem é naturalmente egoísta e mau, e terá de sujeitar-se a um Estado "Leviatã" para preservar a paz e evitar a guerra de todos contra todos, no entendimento espinosiano, como se depreende de sua filosofia, o homem não é necessariamente mau e egoísta. Ele é como é, tal como todas as coisas, agindo naturalmente em virtude de regras naturais, as leis da natureza, que determinam o comportamento de tudo e todos. Um comportamento assim ditado inexoravelmente não pode ser tachado de bom ou mau, ele é absolutamente lídimo. E ao associar-se, não pode ser crível para ninguém que o homem o faça para abrir mão de sua potência e direitos, mas antes para ampliálos.

E deste modo, as instituições não seriam criadas como um fim em si mesmas, prescrevendo regras bisonhas e obtusas a que os seres humanos teriam de se submeter, mas para serem instrumentos fomentadores da preservação da vida e da felicidade.

O cidadão cederia para essas instituições uma pequena parcela de seus bens e direitos, em troca de um bem maior, usufruindo de uma maior liberdade. É o que resta claro da seguinte passagem de Espinosa 130: "Ninguém pode jamais transferir tão radicalmente seu poder a outro e, por conseguinte, seus direitos, a ponto de deixar de ser um homem".

\footnotetext{
129 ESPINOSA. TRATADO POLÍTICO, op. cit. p. 318.

130 IDEM. TRATADO TEOLÓGICO-POLÍTICO, apud SCRUTON, Roger, op, cit. p. 109.
} 
Qualquer que seja, então, a cessão de direitos que possamos transferir para o Estado, em troca de uma maior rede relacional de serviços e segurança, sempre teremos naturalmente de conservar uma parcela de direitos inalienáveis, tais como a vida e a liberdade.

Quando Espinosa fala em "sem deixar de ser um homem", já preconiza, aqui, a salvaguarda da dignidade humana, hoje letra indispensável, implícita ou explicitamente, em todas as constituições contemporâneas. Lá atrás, no poente da idade medieval, ele já pregava como limite ao poder sancionatório do Estado a observância obrigatória da dignidade do ser humano.

Outra grande divergência com o pensamento hobbesiano, nesta questão de organização social e política, refere-se ao respeito aos regulamentos e contratos, como antes já mencionado neste trabalho. Assim, para Espinosa, não haveria lugar, sempre e em quaisquer situações, para uma obediência cega e irretratável aos contratos e compromissos assumidos, uma vez que as circunstâncias de momento poderiam ser distintas das então presentes na celebração dos mesmos. E, nesse caso, a ruptura desses pactos seria totalmente legítima.

É o que se deduz da seguinte passagem: "Aliás, ninguém contrata com vista ao futuro, senão considerando as circunstâncias presentes, e se tais circunstâncias se alteram, a própria situação se altera inteiramente". ${ }^{131}$ Também, como vimos já neste trabalho, as ideias de Hobbes sobre o assunto eram diametralmente opostas, uma vez que este advogava a observância irrestrita dos compromissos assumidos em nome da preservação das instituições.

Como bem salienta Hadi Rizk ${ }^{132}$, Espinosa sujeita qualquer transferência de direitos, que deva acompanhar uma promessa, a uma condição rigorosa: a nossa obrigação em relação ao outro só o é na medida estrita em que lhe transfiramos o poder, originalmente nosso, de nos obrigar a isso. Ou seja, a promessa terá de ser acompanhada da transferência total de nossa potência. Ela só geraria uma obrigação na medida da transferência simultânea do poder de nos obrigarmos. E como isso não acontece, uma vez que promessa é distinta do poder efetivo de nossa potência natural, continuamos com a faculdade de nos obrigarmos ou não.

131 ESPINOSA. TRATADO POLÍTICO, op. cit. p. 324.

132 RIZK, Hadi, op. cit. p. 169. 
Daí que não poderá haver nunca servidão permanente, regimes políticos perenes, nem constituições eternas. Nossa potência natural nunca nos abandonará, pelo simples fato de que é natural. Mesmo apesar de adormecida e amordaçada na servilidade aos poderosos, cedo ou tarde, acordaremos com um lampejo súbito da consciência de que somos humanos, dotados de um poder racional de conhecimento e poder naturais.

Em síntese, a origem do Estado não está nem numa concessão divina, seja ela direta ou indireta, nem tampouco no contratualismo moderno com sua transferência do poder e autonomia individuais a quem quer que esteja no poder. A origem do Estado está no consenso, em que a delegação de poderes é apenas parcial e sempre será compartilhada e rediscutida por todos, numa ordem constituinte e dinâmica da política. Mais, o fundamento do Estado não pode ser meramente jurídico, mas, antes, de fundo sociológico. 


\subsection{CRÍTICA À RELIGIÃO E AO REGIME TEOCRÁTICO}

O termo teocracia vem do grego theos (Deus) e kratos (poder) e significa um regime político em que o poder temporal reputa-se emanado diretamente de Deus, e é concedido a profetas, sacerdotes ou até monarcas para o exercerem com exclusividade, já que investidos do poder pela autoridade mais poderosa existente.

São muitas as nuances do regime, ora mais fundamentalistas, ora mais flexíveis, mas com a característica comum de pretenderem regular a vida em sociedade pela cartilha da religião e dos dogmas hieráticos.

Uma das causas que poderá ter levado os homens a obedecer a esse tipo de regime pode ter sido o horror às calamidades naturais, atribuindo-as a caprichos dos deuses, levando-os ao estabelecimento de uma suposta aliança com esses mesmos deuses, por intermédio dos Profetas, a fim de aplacar a sua ira.

Epicuro, de acordo com Leo Strauss ${ }^{133}$, já enfatizava que era a ignorância das causas naturais dos fenômenos físicos, principalmente os fenômenos celestes, que infligiam ao homem o medo dos deuses. E Sextus Empiricus, segundo o mesmo autor, corroborava esse entendimento, afirmando que era a partir de acontecimentos inesperados e que atingiam o espírito, a partir de acontecimentos maravilhosos operados no mundo, que os homens eram levados a forjar uma representação e um domínio dos deuses, atribuindo-lhes a produção dos fenômenos naturais com o único fim de afligir os humanos.

Para lutar contra esses medos e angústias, o homem teria dois caminhos: ou a descoberta da verdade através da ciência e da filosofia, tal como preconizado por Epicuro, ou por uma suposta aliança com os deuses, levada a cabo pelas sociedades mais primitivas e carentes, de modo a aplacar as suas iras e trazer benesses em vez de calamidades.

Para Epicuro, Demócrito, e para a maior parte dos filósofos antigos, como présocráticos, estóicos, cínicos, há uma confrontação bem nítida entre as categorias

133 STRAUSS, Leo, op. cit. p. 22. 
míticas ou religiosas e as categorias científicas: as míticas, pressupõem o indeterminado, o súbito, o inesperado, o poder dos deuses operarem milagres, as vindictas e sanções que aterrorizavam os homens crédulos e ignorantes; já as científicas, prescreviam a regularidade dos fenômenos na natureza, a continuidade, o previsível, a negação do milagre e da decretação das catástrofes pela má conduta humana, liberando assim a humanidade dos cultos com base no terror.

Segundo Leo Strauss ${ }^{134}$, é preciso ver nessa iniciação científica e filosófica os fundamentos das teorias de Hobbes, Espinosa, Hume, D'Holbach, Feurbach, Bruno e Marx, uma grande tradição filosófica que se estende até nossos dias.

Secundando esse ideário principalmente epicurista e atomista, filósofos como Averróis e Maimônides fariam nascer, tanto as religiões, como determinados regimes políticos, de uma necessidade para se assegurar a vida em sociedade das multidões ignorantes. E esta tarefa caberia a uma classe de indivíduos tidos por superiores, em capacidade e liderança, os Profetas, que, guiados pela imaginação e pelos sonhos, e por meio de ameaças e promessas de recompensas divinas, constrangiam as massas ignaras a seguir o caminho da obediência. "É assim que a religião é também para os príncipes um excelente meio de controlar seus povos e dominá-los"135. Isso, segundo Leo Strauss ${ }^{136}$, seria ponderado mais tarde por Maquiavel, o qual faria uma apologia ao Cristianismo, baseada na ascendência e disciplina que a religião seria capaz de exercer sobre o povo, a ponto de refreá-lo. De acordo com esse autor ${ }^{137}$, este julgamento de Maquiavel não se fundamentaria num mero cálculo político, mas numa profunda simpatia por aquilo que era original, autêntico, face à decadência e corrupção que grassavam no seu tempo.

Segundo Juan Antônio Estrada ${ }^{138}$, uma das características básicas da criação dos mitos, presente em todas as civilizações, é a fusão entre Deus, o mundo e o homem. Os mitos sempre pressupõem essa união, e por detrás deles, na sua

\footnotetext{
${ }^{134}$ STRAUSS, Leo, op. cit. 24.

135 Ibid., p. 28.

136 Ibid., p. 29.

137 Ibid..

138 ESTRADA DIAZ, Juan Antonio. DEUS NAS TRADIÇÕES FILOSÓFICAS, Vol. 1, tradução Maria A. Diaz, São Paulo: Paulus, 2003, p. 36.
} 
origem, está a noção do caos e o sentimento da fragilidade do homem e de sua consciência da finitude. Ou seja, este sentimento e percepção humana de sua impotência e fragilidade, do terror de encarar o fim da existência, ou o temor da morte violenta sempre à espreita, forçaram o homem à criação dos mitos e teogonias. Ainda, de acordo com este mesmo autor ${ }^{139}$, a etapa inicial de desordem e violência cede lugar a um estágio de ordem e justiça, devido à ascensão e consolidação de Zeus como a máxima autoridade divina, o qual instauraria uma completa ordem cósmica, social, política e jurídica.

Numa sequência natural da evolução do pensamento humano, vê-se, por exemplo, que no direito romano, de acordo com Ari Solon ${ }^{140}$, as leis tinham por fundamento, não a vontade de um Estado herdeiro do direito natural, mas os auspícios divinos. Como citado por este autor:

"A fé mágica é uma das fontes originárias do direito (...)". "Mesmo em estágios
jurídicos sob outros aspectos desenvolvidos, toda a ação era originalmente ex delicto
sendo totalmente desconhecidos os "deveres" e "contratos". "Os contratos primitivos
(...)implicavam uma transformação da qualidade jurídica global das pessoas. Para
produzir tais efeitos, esses contratos eram originariamente e, sem exceção, ou
diretamente atos mágicos, ou então atos com significação mágica, conservando
durante longo tempo em seu simbolismo traços destas características"141. Ainda segundo o mesmo autor ${ }^{142}$, o direito criado pelos romanos estava sujeito à lei divina, da qual obtinha seu poder, e se submetia a formalidades oriundas dos auspícios divinos. Assim, o direito era visto como uma força divina oculta em prol da nação e da família. Corroborando este pensamento, Fustel de Coulanges ${ }^{143}$ afirma que "entre os gregos e entre os romanos, e também entre os hindus, a lei foi, de início, parte da religião" e, "o direito era tão-somente uma das faces da religião".

Também os hebreus, como qualquer outro povo, assimilaram as tradições mitológicas preexistentes, como fontes produtoras do direito e das instituições, e procuraram adaptá-las ou reformá-las às suas condições particulares e especificidades de seus costumes.

\footnotetext{
139 ESTRADA DIAZ, Juan Antonio, op. cit. p. 37 - 38.

140 SOLON, Ari Marcelo. Direito e tradição: o legado grego, romano e bíblico. Rio de Janeiro:

Elsevier, 2009, p. 28.

141 Ibid., p. 29

142 lbid., p. 20 - 21.

143 COULANGES, Fustel de. La Cité Antique, apud SOLON, Ari Marcelo, op. cit. p. 76.
} 
Assim, a ideia da criação na Bíblia, traduz-se como a ideia da superação do caos e da desordem reinantes: "No princípio Deus criou os céus e terra; e a terra era sem forma e vazia; e havia trevas sobre a face do abismo; e o Espírito de Deus se movia sobre a face das águas". ${ }^{144} \mathrm{E}$ Juan Antonio Estrada ${ }^{145}$, comentando esta passagem bíblica, afirma que "Deus pôs ordem com a sua palavra, com a qual acentua a transcendência divina a respeito da fusão mítica entre cosmo e divindade".

Uma particularidade e inovação dos hebreus, é que eles não viam o mundo como physis, como um cosmos submetido a uma ordem divina e imanente, tal como o viam os antigos gregos, e mais tarde o veria também Espinosa. Os hebreus viam o mundo como um devir histórico, contínuo, com princípio, meio e fim, após o ato da Criação. O mito, como fusão entre o divino, o cósmico e o humano, foi reelaborado para surgir a transcendência divina.

E esta ideia da transcendência divina, apartada da fusão entre o divino e o cósmico, com a sua necessariedade de uma cadeia de leis naturais, é crucial para a análise da origem de um novo regime teocrático, distinto de outros regimes então vigentes.

No Egito, por exemplo, vigia um regime absolutista, mas à sombra de uma especial teocracia, já que o faraó era encarado como a personificação divina. Os deuses que os egípcios adoravam eram as forças benfazejas da natureza das quais se nutriam, tal como o Nilo e o Sol. Do Sol e do Nilo nasciam as riquezas dos egípcios, e por essa razão eles os idolatravam na pessoa do faraó. Os decretos deste eram como se fossem emanados de tais divindades.

O Deus Nilo representava a contenção dos desertos, e a própria ressurreição da morte estava simbolizada na água que, com seu húmus, fertilizava e dava vida regularmente às terras; e o Deus Sol era a vitória diária sobre o caos e sobre as trevas, trazendo a luz dia após dia. Mas esses deuses não eram transcendentes à própria natureza, eram-lhe imanentes, traduziam a physis dos gregos e dos demais povos orientais. Akhenaton talvez tenha procurado fugir a essa tradição cósmica e politeísta, sacramentando o Deus Sol como Deus único, mas, como em

\footnotetext{
144 GÊNESIS $(I, I-2)$.

${ }^{145}$ ESTRADA DIAZ, Juan Antonio, op. cit. p. 38.
} 
quase toda a parte, tradições são para cumprir e nem um faraó tem tanto poder para descumpri-las, e por isso mesmo seu reinado e seu ideário duraram pouco.

Os hebreus foram, pois, inovadores em seu regime religioso e político, ao criarem um Deus transcendente e uma lei emanada diretamente dele pela voz dos Profetas. Talvez essa mudança histórica se deva às vicissitudes pelas quais passaram, à amargura de uma longa escravidão tendo de adorar deuses alheios, à carência de terras e lugares só seus, o que lhes terá aguçado a crença na esperança em algo sobrenatural e deles exclusivo.

Como relata Juan Antonio Estrada ${ }^{146}$, a fusão Deus - homem - mito, tão característica das civilizações orientais, cede lugar a uma sociedade e economia diferenciadas, que desdivinizou e dessacralizou a natureza, afastando-se das origens míticas (as teogonias dão lugar à história), e acabou por revalorizar o indivíduo face ao coletivismo inicial.

Dessa ideia de transcendência divina, advogada pelos teólogos judeus, e revitalizada mais tarde por Maimônides, surge o mito da criação do mundo, ideia contra a qual se insurgiria Espinosa e que the causou o banimento da comunidade judaica.

Os Profetas hebreus precisavam criar um Deus todo poderoso, transcendente e voluntarista, o qual pudesse alterar a ordem natural das coisas, as leis físicas da natureza, como e quando quisesse, de preferência sempre a beneficiar seu povo em detrimento de seus inimigos. Assim, a duração do dia poderia ser aumentada, numa hora as águas do Nilo poderiam se afastar para dar passagem ao povo eleito, noutra elas refluiriam para esmagar os exércitos inimigos, etc.

A existência desse Deus era-lhes absolutamente necessária para serem conduzidos em paz e segurança através de desertos inóspitos cercados de inimigos, até alcançarem a Terra Prometida onde brotavam o trigo, o leite e o mel. Sem a existência desse Deus, e sem a esperança de um Deus maior que os deuses pagãos, os Profetas não teriam conseguido conduzir, em relativa segurança e ordem, multidões idólatras através dos desertos.

${ }^{146}$ ESTRADA DIAZ, Juan Antonio, op. cit. p. 40. 
Desse modo, as crenças nos milagres, na alteração das leis físicas da natureza, eram instrumentos necessários para a obediência e a servilidade do povo. A plausibilidade e a veracidade dos milagres teriam de ficar assim justificadas nos Textos Sagrados.

Moisés, como líder experimentado e prudente, teve a perspicácia de enxergar o perigo que rondava aquele povo nômade, de não conseguir o seu objetivo maior, que era $o$ de pisar o solo de uma terra em que fossem finalmente livres. Ele apelou, então, para as forças do sobrenatural, do divino e anteviu que só o culto concentrado a um Deus único - tal como o culto ao Deus único do faraó Akenaton - poderia insuflar disciplina, temor e esperança naquelas multidões impacientes e hesitantes.

Como atrás já explicado por Strauss ${ }^{147}$, relatos extraordinários da ocorrência de fenômenos inusitados e poderosos poderiam mexer com a imaginação e a credulidade do povo. Pois, este povo sofrido, castigado pelas intempéries e forças da natureza, açulado por inimigos mais poderosos, seria facilmente manipulado e sugestionado pela viva imaginação de um Profeta, experimentado e vivido, apelando para $\mathrm{o}$ irracional e para o espantoso.

As leis e decretos dos soberanos são passíveis de desobediência e de afronta, porque as penalidades são terrenas, suportáveis, previsíveis, ainda que cruéis ou sanguinolentas. Mas os decretos divinos, emanados do Deus onipotente, todo poderoso, seriam muito mais difíceis de afronta ou desobediência. As sanções para o não cumprimento seriam eternas, terríveis, podendo até contaminar e condenar futuras gerações inocentes.

O legislador hebreu, com sua perspicácia e liderança, foi longe nos seus objetivos e soube plantar a semente da obediência e fidelidade absolutas. A um povo habituado à escravidão e à sobrevivência nos desertos, não foi muito difícil substituir a servidão temporal pela espiritual. E além do mais, esse Deus que poderia até ser terrível e vingativo na punição dos pecados, poderia se mostrar também generoso e compreensivo para com os justos. À cólera e à vingança poderiam muito bem suceder o perdão, a misericórdia e a justiça.

Acima de tudo, esse Deus era privativo, era o Deus de Israel e de um povo eleito, condutor e condestável dos exércitos de Israel, $\mathrm{O}$ qual esmagaria as forças inimigas e dominaria as forças da natureza.

De acordo com Leo Strauss ${ }^{148}$ é comum nos homens a crença de que Deus pode alterar a ordem natural das coisas em seu favor. Os judeus costumavam atribuir uma interpretação milagrosa ao alongamento sazonal do dia para fazer convencer

\footnotetext{
147 STRAUSS, Leo, op. cit. p. 135.

148 Ibid., p. $175-176-177$.
} 
aos outros que eram o povo favorito de Deus. A lendária abertura da passagem através do Mar Vermelho, permitindo a passagem do povo eleito e o solapamento do exército egípcio, é relatada como um fenômeno espetacular, milagroso, que não emocionaria as almas se fosse descrito como uma narração sóbria sobre o evento natural de um ciclone tropical.

Deus teria, portanto, toda a liberdade para agir ou não agir, fazer ou não fazer, mudar isto e aquilo, aqui e agora, ou até não mudar nada se preferisse. Ora, ainda de acordo com o mesmo autor ${ }^{149}$, as críticas a esta posição são muito comuns e basicamente são as seguintes: todo o agente minimamente inteligente quando age, o faz movido por interesses, sejam quais forem, e por ausência absoluta de barreiras a essa ação; quando não age, é porque não tem interesse, ou não tem vontade, ou encontra barreiras. Ora, Deus não pode, nem ter vontade, nem ser movido por interesses externos, nem tampouco ser impedido por quaisquer obstáculos. Ele é Ato Puro e não seria de sua natureza ora agir, ora não agir.

Segundo Leo Strauss ${ }^{150}$, Maimônides tenta responder a estas críticas enfatizando que não há, com efeito, incitações ou obstáculos determinando Deus a agir num caso e a não agir em outro, mas é a Sua vontade que se determina nos dois casos. O propósito da vontade é tanto querer como não querer, já que a sua essência é a espontaneidade e Deus poderá agir ou não, não sendo isso sinal de imperfeição, mas atributo essencial da própria vontade.

Ora, para Espinosa, segundo Marilena Chauí151, a vontade e o intelecto não pertencem à natureza de Deus, pois Ele age legibus suae naturae, ou seja, segue necessariamente as leis de Sua natureza divina. A liberdade do poder divino não seria outra coisa senão a necessidade da natureza divina. Ainda, segundo a mesma autora ${ }^{152}$, a potência absoluta de Deus, que se presume infinita, não pode de maneira alguma se render a algo que Ihe seja exterior, e seria exatamente por isso que Ele não pode dispor de vontade, pois toda vontade pressupõe escolhas entre objetos possíveis, ou contingentes, e na natureza tudo é necessário e não há lugar para o contingente.

\footnotetext{
149 STRAUSS, Leo, op. cit. p. 176 - 177.

150 lbid.

151 CHAUÍ, Marilena, op. cit. p. 869.

152 lbid., p. 914.
} 
Explicando melhor, Espinosa, que advoga a tese da eternidade e necessariedade do mundo, dela deduz a impossibilidade do milagre. Segundo esta sua proposição:

"A vontade de Deus e seu entendimento são na realidade a mesma coisa e não se
distinguem senão relativamente ao pensamento que formamos em relação ao
entendimento divino. (...) Decorre desta proposição que Deus quer tudo o que
conhece e que por consequência a diferença entre o possível e o real não tem
significação ontológica: não há lugar para um possível ao lado do real, ou fora do real,
e o real é necessariamente tal como é: as regras da produção real das coisas são leis
necessárias, verdades eternas. A alteração da natureza, a negação de uma lei
natural, o milagre, é um absurdo..153.

Ou seja, a vontade de Deus e seu entendimento são, na verdade, a mesma coisa e não se distinguem senão relativamente à compreensão que formamos a respeito do que seja o entendimento divino. Deus quer tudo aquilo que conhece e, consequentemente, a hipotética diferença entre o possível e o real não tem qualquer significação. Não há lugar para a hipótese de uma coisa possível em vez da existência de uma coisa real, porque o real existe necessariamente: as regras da produção real das coisas são leis necessárias, são verdades eternas. Portanto, qualquer alteração da natureza, a hipotética negação de uma lei natural, a existência do milagre, não passam de absurdos criados pela ignorância humana.

Para Maimônides, segundo Strauss ${ }^{154}$, Deus teria inteira liberdade de agir ou não agir, de querer ou não querer, e sua presciência ou omnisciência seriam independentes da vontade. Portanto, Deus poderia ter previsibilidade e ciência absoluta dos atos humanos, e mesmo assim conferir aos homens o livre arbítrio de agirem e se conduzirem desta ou daquela maneira. Mas, ao mesmo tempo, a concluir-se da possibilidade dos milagres, e de uma ruptura da ordem natural das coisas, Deus poderia voltar atrás em suas decisões por um simples ato de sua vontade, inesperadamente, decisões essas já antes previstas no entendimento divino e cassar repentinamente o mencionado livre arbítrio humano. Para conciliar este evidente conflito de competências entre os poderes divinos da ciência e previsibilidade, da sua vontade plenamente livre, criou-se a figura da insondabilidade dos mistérios divinos, pela qual os desígnios de Deus são inatingíveis.

153 ESPINOSA. TRATADO TEOLÓGICO-POLÍTICO, apud STRAUSS, Leo. op. cit. p. 175.

154 STRAUSS, Leo, op. cit. p. 177. 
Ora, Espinosa, como já visto, rejeita toda essa construção, porque agrediria a lógica das coisas, e o sistema das leis da causalidade, que por toda parte se observa na natureza.

Haveria uma identificação completa entre o entendimento divino e a sua vontade, a união entre a ciência absoluta, manifestada na previsibilidade das coisas, e o querer divino, o que tornaria inverídica a existência dos milagres e a ruptura com a ordem natural emanada do próprio Deus. A ideia da vontade divina distinta de seu entendimento seria, assim, fruto da ignorância humana.

Então, consequência inevitável, não há possibilidade da existência das leis da revelação. Necessariamente, não haveria possibilidade de haver uma religião revelada com edição de leis divinas a serem cumpridas pelo homem, e com a cominação de sanções punitivas em caso de descumprimento.

As leis, portanto, baixadas por Moisés como divinas, seriam impossíveis. Pois, se uma lei é proveniente de Deus, em virtude de seus poderes absolutos de ciência e vontade infinitas, essa lei seria impossível de ser desrespeitada pelos homens. Como diz Leo Strauss ${ }^{155}$, "uma lei é, em tanto que tal, qualquer coisa que pode ser transgredida, e se Deus quer tudo o que conhece, uma ação do homem contra a vontade de Deus, ação que seria, portanto, conhecida por Ele, Todo Poderoso, seria impossível".

Logo, uma lei revelada por Deus é impossível de se conceber. Consequência deste raciocínio: as leis emanadas de Moisés, como divinas, seriam uma construção do próprio legislador hebreu, obrigado por uma necessidade premente de estabelecer um rigor excessivo, a fim de conduzir, em segurança, um povo nômade à sua pátria prometida, por um longo caminho desconhecido, cercado de todos os perigos e de fortes inimigos.

Daí decorre também, para Espinosa, a inexistência da ideia pecado, na relação do homem com Deus. Não há pecado possível, porque impossível é a transgressão a qualquer mandamento divino. Pois, de acordo com Hadi Rizk ${ }^{156}$, se Deus tivesse estabelecido determinada proibição, como por exemplo a famosa

\footnotetext{
155 STRAUSS, Leo, op. cit. p. 178.

${ }^{156}$ RIZK, Hadi, op. cit. p. 150.
} 
proibição bíblica " não quero que comas do fruto da árvore da ciência do bem e do mal" teria sido impossível a transgressão desse mandamento por Adão, como impossível seria toda a transgressão a qualquer mandamento divino, dada a necessidade absoluta das leis divinas.

Ora, temos então que os Dez Mandamentos jamais poderiam ter sido desrespeitados, já que, como Deus é Todo Poderoso por natureza, um mandamento Seu fatalmente teria de ser cumprido, caso contrário, ou o mandamento não seria Seu, ou Ele não seria Deus.

De onde se é levado a concluir que os Dez Mandamentos não tiveram origem divina, e foram inventados pelos Profetas, a fim de poderem estabelecer uma obediência cega do povo a seus preceitos. $E$ essa obediência seria absolutamente necessária, dada a carência, a falta de meios, a falta de terra, e a fraqueza ante inimigos mais poderosos econômica e militarmente.

O povo judeu, pois, tendo feito um pacto com o próprio Deus, por intermédio de homens mais poderosos ou mais astutos do que eles - os Profetas - aceitavam essa submissão total aos decretos divinos, essa servidão espiritual e temporal, pois o descumprimento acarretaria, além das penas eternas como sanção, a falta de proteção e o aniquilamento total, face aos inimigos e às forças da natureza.

Segundo Espinosa ${ }^{157}$ :

"A Escritura, quando diz que Deus está zangado com os pecadores, e que ele é um juiz que toma conhecimento das ações humanas, as sentencia e julga, está falando em termos humanos e de um modo adaptado às massas, pois seu propósito não é ensinar filosofia, nem tornar os homens sábios, mas torná-los obedientes".

Assim, para os homens carentes, com pouco discernimento, dominados pela força das paixões e da imaginação, o hábito de uma obediência cega aos mandamentos divinos seria um guia seguro para a paz e o prosseguimento da jornada.

Espinosa chamava esse regime político da teocracia de uma democracia fraca, pois, como comentado por Hadi Rizk ${ }^{158}$ :

"É democracia porque, por pertencer a Deus, o poder não pertence a ninguém; este regime preserva também a unidade do povo e garante a igualdade entre os indivíduos. A unificação pela crença religiosa - servir a Deus é servir ao Estado suscita uma adesão pessoal muito forte e permite uma boa integração dos indivíduos sobre um poder comum."

157 ESPINOSA. TRATADO TEOLÓGICO-POLÍTICO, apud SCRUTON, Roger, op. cit. p. 103.

158 Ibid., apud RIZK Hadi, op. cit. p. 154 - 155. 
Para Espinosa, ainda segundo o mesmo autor, as vantagens dessa democracia fraca, tais como a relativa igualdade de seus membros, a preservação da unidade do povo, a paz e segurança impostas pelos Profetas mediante decretos divinos cominando sanções eternas ao descumprimento - o que trazia também uma certa dissuasão ao abuso de poder - não compensava os enormes prejuízos para a liberdade e o aperfeiçoamento humanos. Assim, os costumes e as atividades ficariam engessados e limitados pelas instituições religiosas, impedindo a evolução natural, mormente o intercâmbio entre as ideias e trocas comerciais com os povos vizinhos.

A forte impregnação religiosa da vida cotidiana obstaria ao desenvolvimento racional da existência, pelos limites impostas à razão pela religião. E, acima de tudo, as sagradas liberdade de expressão e autonomia dos cidadãos ficariam tolhidas, havendo uma subserviência total aos dogmas religiosos. Estes, como tais, não poderiam ser questionados pelo espíritos mais lúcidos ou rebeldes.

Ora, esta submissão e obediência cegas aos dogmas religiosos que não poderiam ser questionados, nem libertados pela luz da razão, tenderiam a originar uma opressão mais dura e fechada para poderem resistir aos anseios naturais dos homens, os quais sempre aspiram por maior liberdade e potência de agir, que no fundo é a sua potência natural.

Citando Hadi Rizk ${ }^{159}$, o aumento da potência de agir dos indivíduos, já que reunidos num regime de democracia fraca tal como denominado por Espinosa, levaria a questionar o rigoroso equilíbrio entre as instituições e os costumes, podendo aniquilar o regime por fim. A autarquia religiosa estatal, ao alçar seus preceitos morais em regras de direito, engessaria todas as relações, fossem elas sociais, comerciais, ou até entre povos estrangeiros. E o indivíduo que não professasse a religião oficial, ou até que não frequentasse seus cultos com a frequência estabelecida, não seria apenas considerado impiedoso, mas também deixaria de ser cidadão e seria afastado do convívio social.

O regime teocrático para persistir e conservar-se precisaria, cada vez mais, de fechar-se sobre si mesmo, cerrar as portas à civilização, à ciência, e tentar sufocar a fome de liberdade e do exercício da potência natural dos indivíduos. E isso fatalmente levaria à sua ruptura.

Para Espinosa, segundo o mesmo autor ${ }^{160}$, uma das causas da degeneração do regime teocrático em monárquico, e deste em tirania, no caso dos hebreus, terá sido a concessão exclusiva da interpretação das leis aos levitas. Apesar de isso trazer uma certa hegemonia do poder político sobre a religião, impedindo assim os sacerdotes de usurparem o poder temporal e configurando uma certa divisão

159 RIZK, Hadi, op. cit. p. 165.

160 lbid., p. $154-157$. 
de poderes, esse poder político cresceu desmesuradamente, transformando-se em absoluto.

O fechamento de qualquer regime totalitário, incluído o teocrático, que necessário à sua sobrevivência, conduz fatalmente à tirania. Mas, conforme Espinosa, citado por Leo Strauss ${ }^{161}$, "A teocracia se transforma necessariamente em poder tirânico, e o poder tirânico de um ente nunca se impões por muito tempo".

Com efeito, a necessidade do exercício da potência natural dos indivíduos faz quebrar as amarras de regimes arcaicos, desatualizados, que, em vez de tentarem favorecer, bloqueiam o impulso de autopreservação evolutivo, que é natural no ser racional. A razão sempre procura descobrir novas formas do exercício livre da potência dos indivíduos.

Em síntese, a crítica que Espinosa faz ao regime teocrático é basicamente a mesma que faz a qualquer regime autoritário, ainda que amparado por um hipotético contrato ou uma real constituição, ou seja, rejeição absoluta a uma integral alienação dos direitos de cada um. Só que, quanto ao regime teocrático, essas críticas são ainda mais contundentes, porque essa suposta alienação do poder às autoridades religiosas está alicerçada no total obscurantismo, no medo do sobrenatural, no receio das sanções divinas ao comportamento humano, e a exploração do homem pelo homem é continuamente reforçada, amenizada e legitimada pelo medo de sanções divinas e pela crença de um futuro promissor no além.

${ }^{161}$ STRAUSS, Leo, op. cit. p. 289. 


\subsection{REGIME POLÍTICO IDEAL}

Como relatado em capítulos precedentes, o Estado teria surgido de uma clivagem entre a ordem natural das coisas, em que os indivíduos só dispunham de suas potências singulares para a sua autopreservação, e a ordem social e moral, surgida posteriormente com as sociedades organizadas.

Também vimos que nos primórdios de sua existência, ou seja, na ordem natural, os indivíduos prescindiam de regramentos sociais, das noções do certo e do errado, do justo e do injusto. Nesse limiar da existência humana, força e direito significavam a mesma coisa, equivaliam singelamente à potência de cada um.

Mas a necessidade de aportar mais potência e direitos às frágeis potências singulares, ou de tornar eficazes essas fracas potências individuais face à agressão perpetrada por potências maiores, obrigou os indivíduos a se reunirem em torno de comunidades organizadas.

O sentimento de que a autopreservação corria perigo iminente sem o concurso de outras potência semelhantes, levou o ser humano à associação. Como diz Espinosa 162 "os homens, com efeito, não nascem cidadãos, mas formam-se como tais". Daí, a conclusão de que o homem não é necessariamente bom por natureza, como pretendia Rousseau e os reformadores utópicos, mas, quando prudente e sábio, busca obedecer às regras da sociedade no seu próprio interesse de sobrevivência.

A justificação do Estado fundamenta-se na necessidade do estabelecimento de uma potência coletiva reguladora, embora preservando, tanto quanto possível, as liberdades das várias potências individuais. Sem liberdade, não há desenvolvimento possível.

A finalidade última do Estado, como prega Espinosa ${ }^{163}$,

“(...)não é dominar os homens nem sujeitá-los pelo medo e submetê-los a outro, senão, ao contrário, liberá-los a todos do medo para que vivam, em quanto seja possível, em segurança; isto é, para que conservem ao máximo seu direito natural de

162 ESPINOSA. TRATADO POLÍTICO, op. cit. p. 328.

163 IDEM. TRATADO TEOLÓGICO-POLÍTICO, apud NEGRI, Antonio. op. cit. p. 51. 
existir e de agir, sem prejuízo para si nem para seus semelhantes. A finalidade do Estado não é, muito menos, transformar seres racionais em animais e máquinas. Deve, sim, habilitar os corpos e mentes dos cidadãos a funcionarem com segurança. É orientar os homens para que exerçam sua livre razão e vivam dentro dela; para que não desperdicem sua energia em ódios, vinganças e traições, nem ajam injustamente uns para com os outros. Assim sendo, a finalidade do Estado é, pois, a liberdade".

É uma constante em toda a obra de Espinosa a defesa intransigente da liberdade, porque ele já entendia que, assim como o indivíduo precisa de liberdade para desenvolver-se, também o Estado precisava que os dotes e qualidades individuais dos cidadãos pudessem florescer livremente em benefício de toda a sociedade. $\mathrm{O}$ estigma do medo e da opressão só poderá coibir e engessar esse desenvolvimento.

Segundo Edwin Curley ${ }^{164}$, Hobbes defendia que o soberano tinha de ter controle absoluto sobre todas as doutrinas e ideias publicadas em livros, ou até ensinadas em escolas e igrejas, pois as ações dos homens procedem sempre de suas opiniões, e controlando estas, controlar-se-iam aquelas. Já Espinosa defendia que deveria haver uma total liberdade de pensamento e crença: "Num estado livre é lícito a cada um pensar o que quiser e dizer aquilo que pensa (Tratado teológico-político, XX, título)".

Mas essa liberdade só deverá ser plena no tocante à liberdade de criação, de pensamento e de opinião, e não à plena e irrestrita liberdade de agir, de fazer ou destruir, desrespeitando as regras da sociedade em que o cidadão está inserido. Pois, pensar e agir são coisas distintas. O pensamento e a opinião expressos sobre determinadas leis ou eventos políticos são em si inócuos e pacíficos, e se acaso tiverem a anuência da maior parte da sociedade, a qual concorde em princípio com seus termos, poderão até levar ao aperfeiçoamento das leis ou instituições.

Agora, agir de acordo com suas ideias, mas contrariando as regras previamente estabelecidas pela maioria democrática, é rebeldia e não deve ser permitido, punindo-se o infrator. De acordo com o seu pensamento, como citado por Roger Scruton ${ }^{165}$ :

\footnotetext{
"Supondo que um homem mostre que uma lei repugna a reta razão e deve por isso ser rejeitada; se ele submete sua opinião ao julgamento dos supremos poderes (que são os únicos a ter o direito de fazer e rejeitar as leis) e entrementes não age de modo algum contrariamente a essa lei, ele serviu bem ao Estado; mas se ele acusa os magistrados de iniquidade, e atiça o povo contra eles, ou se luta de maneira sediciosa para revogar a lei sem seu consentimento, é um mero agitador (perturbator) e um rebelde".
}

164 CURLEY, Edwin. Kissinger, Spinoza e Genghis Khan. IN: SPINOZA. GARRETT, Don (Org.) Aparecida/SP: Ideias \& Letras, 2011, p. 394.

165 SCRUTON, Roger, op. cit. p. $106-107$. 
Porém, se as leis são injustas, e amordaçam ou, de qualquer maneira, limitam as liberdades individuais além do razoável, seria permitido aos cidadãos desrespeitálas e fazer justiça com suas próprias mãos?

Parece-nos que o pensamento de Espinosa, embora sempre tão cioso da liberdade humana, seria contra essa usurpação singular e isolada do poder de interpretar e aplicar as leis do Estado, poderes esses que só caberiam às instituições estatais especializadas. Senão, vejamos:

\begin{abstract}
"Além disso, não podemos conceber que seja permitido a cada um interpretar os decretos da cidade (Estado), isto é, as suas leis. Se houvesse tal permissão, ser-seia, com efeito, seu próprio juiz. (...) Vemos, portanto, que cada cidadão depende não de si mesmo, mas do Estado às injunções do qual é obrigado a obedecer, e que ninguém tem o direito de decidir o que é justo, o que é injusto, o que é moral ou imoral, mas, pelo contrário, visto que o corpo do Estado deve ser conduzido de certo modo por um pensamento único, e que, consequentemente, a vontade do Estado deve ser tida como a vontade de todos, é o que o Estado decreta ser justo e bom o que cada um deve aceitar como tal. Portanto, mesmo se o súdito julga iníquos os decretos do Estado, é contudo obrigado a submeter-se-Ihes"166.
\end{abstract}

Bem entendido, parte-se do princípio, aqui, de que esse Estado e essas leis por ele emanadas presumem-se dentro de um quadro de estrita normalidade e legalidade absoluta, seja esse Estado uma democracia ou uma monarquia constitucional.

Certamente, não se deverá falar em obediência estrita e cega a mandamentos provenientes de um Estado usurpador da legalidade, sob o comando de um tirano, alçado à condição de monarca todo poderoso, porque, como também já vimos em capítulos precedentes, há certos direitos inerentes à pessoa que são por sua natureza inalienáveis e inegociáveis.

Assim, um Estado déspota que não respeite o direito à vida, à liberdade, nem as mais elementares condições de sobrevivência de um ser humano, não mereceria obediência, e ensejaria contra si a luta de seus súditos espoliados e atingidos em suas potências legítimas de usufruto de seus direitos originários.

Além do mais, ninguém pode ser obrigado a fazer ou não fazer o que for contra a sua natureza racional, à sua autopreservação, sob pena de desobediência generalizada. Deste modo, doutrina Espinosa ${ }^{167}$ :

\footnotetext{
"Daí a consequência que todas as ações às quais ninguém pode ser incitado nem por promessas nem por ameaças estão fora dos desígnios do Estado. Ninguém, por exemplo, pode abdicar da sua faculdade de julgar; perguntemos por que promessas ou ameaças poderia um homem ser levado a crer que o todo não é maior do que a parte, ou que Deus não existe? (...) De uma maneira geral, como poderia ser levado a crer no que é contrário ao que sente e pensa? (...) A testemunhar contra si mesmo? A torturar-se (...) e outras coisas tais a que, nem promessas ou ameaças, possam forçar ninguém. (...) Com efeito, que seria, se não um delírio, a lei a que ninguém pode ser constrangido?"
}

166 ESPINOSA. TRATADO POLÍTICO, op. cit. p. 321 - 322.

167 Ibid., p. 322 - 323. 
Como decorrência deste princípio, descortinamos aqui a necessidade da oportunidade e conveniência do uso do bom senso e da prudência dos governantes, tal como exposto já com muita clareza, séculos antes, por Maquiavel. Este, em sua obra "O Príncipe", preconizava que não se devem tomar decisões contrárias à maioria da população, a seus interesses essenciais, sob pena de desobediência, de comoção geral, e revolta contra os poderes constituídos e contra quem governa. Corroborando todo este ideário, lê-se em Espinosa $^{168}$ :

"É preciso considerar (...) que uma medida que provoque a indignação geral tem pouca relação com o direito do Estado, pois que, obedecendo à Natureza os homens ligar-se-ão contra ela, seja para se defender de uma ameaça comum, seja para se vingar de qualquer mal e, visto que o direito do Estado se define pelo poder da comunidade, é certo que o poder e o direito do Estado ficarão diminuídos, pois que dá razões à formação de uma frente comum".

Por isso a ênfase que Espinosa coloca no regime democrático, já que as decisões em princípio provêm da maioria, e seriam menos passíveis de desobediência porque hegemônicas.

Como reiteradamente já vimos antes, os seres humanos são governados por duas forças antagônicas: pela imaginação, originária das paixões e impulsos inatos e cujo limite ou freio é o medo e a crença no sobrenatural; e pela razão, virtude dos homens sábios, prudentes, os quais buscam no conhecimento a solução para os problemas e carências da existência. Uma ordem política eficaz terá de satisfazer ambas as forças, harmonicamente, por meio do diálogo e do convencimento, de concessões mútuas, e a democracia é o regime mais apropriado para a consecução dessa tarefa.

Sabemos também que, com a associação dos indivíduos, à ordem natural das potências singulares, sucedeu uma ordem moral e social, traduzida na potência coletiva dos regramentos impostos pela sociedade. Se essa potência coletiva das normas sociais, provier de bases democráticas, aceitas e discutidas por todos, será mais eficaz e menos propensa à desobediência.

Mas a democracia espinosiana, segundo Antonio Negri'169, não é uma democracia que camufle ou mistifique as relações de produção e legitime as relações políticas correntes. É, antes, uma democracia fundada no desenvolvimento das potências individuais, rumo a um fazer coletivo, e capaz de libertar as relações de produção de toda alienação e servidão possíveis. Pois não é necessário alienar a potência singular para se construir o coletivo. O coletivo e o Estado, antes, se devem constituir no pleno florescimento dessas potências singulares. Democracia é a fundação do político, mas legitimado pelo coletivo.

168 ESPINOSA, TRATADO POLÍTICO, op. cit. $322-323$.

169 NEGRI, Antonio, op. cit. p. 42. 
Daí que, segundo o mesmo autor ${ }^{170}$, não poder dizer-se que a democracia espinosiana seja uma democracia constitucional, em sua forma tradicional de divisão de poderes e responsabilidades. Embora possam e devam existir fatores de controle e equilíbrio, estas funções só podem ser expressão de uma potência coletiva constitutiva, em que todo o súdito é cidadão, e todo o cidadão é magistrado, e magistrado aqui significa um cidadão plenamente participativo, seja na feitura das leis, seja na sua execução.

E, continua o mesmo autor ${ }^{171}$, democracia como omnino absoluta, quer dizer, não há lugar nela para nenhuma alienação do poder, seja em relação à sua formação, seja em relação ao seu exercício. Pois, o absoluto é a não alienação, é a não transferência de poderes, é, antes, a liberação de todas as energias sociais num conatus geral que fomente e tonifique a liberdade de todos.

Ainda, segundo Negri ${ }^{172}$, Hegel, ao contrário de Espinosa que rejeitava toda forma de alienação de poder, enfatizava que um governo absoluto deve estar além de todas as singularidades, ou seja, além dos indivíduos, e buscar transformar-se numa infinita e indivisível totalidade.

Ora, se o governo absoluto não se adequa concretamente às singularidades das potências reais, acaba por se encerrar em si mesmo como única fonte normativa, e, como resultado, não teríamos cidadãos, mas apenas súditos completamente despidos de autoafirmação.

Por último, o mesmo autor ${ }^{173}$ conclui, dizendo: a teoria contratualista hegemônica e a dialética hegeliana, com sua ênfase na alienação do poder ao Estado absoluto, só fizeram conduzir ao capitalismo exacerbado e à exploração do homem pelo homem. Ao contrário, Espinosa, ao defender a rejeição absoluta a qualquer forma de alienação de poder, aproximou-se e até antecipou o pensamento de Marx.

Nesta mesma linha de raciocínio de Antonio Negri, Hadi Rizk ${ }^{174}$ afirma que o cidadão não pode ser considerado como mero órgão estatal, existindo por e para o Estado. E essa falência do suposto modelo orgânico teria como consequência que o Estado sempre se apresente com uma unidade fraca, já que tem de deixar intacta aos cidadãos uma autonomia muito ampla. E esta fraqueza do organismo estatal teria de ser compensada com uma adesão sempre revigorada por um jogo complexo de relações, tarefas e comunicação, e pela identificação contínua do cidadão com o Estado, na busca contínua de um denominador comum dos interesses individuais.

\footnotetext{
170 NEGRI, Antonio, op. cit. p. 67.

171 lbid., p. 68.

172 lbid., p. 69 - 70

173 lbid.

174 RIZK, Hadi, op. cit. p. 177.
} 
Voltamos a um dos pensamentos norteadores deste trabalho: temos tantos direitos quanto potência tivermos, e se nos obrigamos é por um período provisório, enquanto essa obrigação nos possa ser útil. Finda essa utilidade, temos todo o direito de voltarmos a negociar, e tentar mudar o status quo vigente.

É o que Alexandre Matheron ${ }^{175}$ denomina "consensualismo instantaneísta":

\begin{abstract}
"Somos nós que decidimos, porque o desejamos, pôr nossas forças próprias à disposição do outro. Mas, precisamente, essa transferência é tão voluntária que cessa de ser uma transferência. Rigorosamente, não transferimos absolutamente nada, visto que nossas forças, fisicamente falando, continuam sendo as nossas, e porque a decisão que as coloca a cada instante ao serviço do outro vem sempre de nós; decidimos obedecer no instante $t 1$, depois no instante $t 2$, etc., e nada nos obriga irreversivelmente. Na realidade, nada passa verdadeiramente da nossa pessoa à do senhor; nós não alienamos nossa potência senão imaginariamente, mesmo se os efeitos sejam reais, e esses efeitos desaparecerão quando cessarmos de crer em sua causa".
\end{abstract}

Por este motivo é que só a democracia tende a funcionar regularmente. Quando a coletividade achar que é chegada a hora da mudança, terá todo o poder e direito de fazê-lo, já que só ela detém efetivamente o poder, ou seja, a potência coletiva natural.

E qualquer regime minoritário, seja aristocrático, seja teocrático, seja plutocrático, qualquer que seja, não terá vida longa, já que fundamentado em privilégios de minorias detentoras de um menor número de potências singulares. Eles só se sustentarão enquanto os seres a eles sujeitos permanecerem embotados na imaginação, na ignorância, e não forem conscientes de sua verdadeira potência natural e razão.

Como muito bem diz Hadi Rizk ${ }^{176}$, obedecemos pelo temor e esperança de que o poder alheio é forte, mas esse poder é forte justamente porque obedecemos. Deixará de sê-lo quando desobedecermos, já que nós é que detemos o real poder coletivo.

Em síntese, Espinosa era francamente favorável à democracia, porque este é o regime mais favorável ao estabelecimento de uma verdadeira liberdade e igualdade: liberdade, porque a não transferência integral do poder ao outro, faz com que se possa desfrutar continuamente de sua potência; igualdade, porque, como decorrência dessa mesma liberdade, sendo o regime em que se opera menor alienação, também será o de menor servidão, com direitos e poderes repartidos equanimemente. E a democracia espinosiana tende a ser uma democracia constitutiva dinâmica, jamais afeta a uma constituição rígida e estática, já que carece de um consenso contínuo, num processo que se renova a cada instante.

175 MATHERON, Alexandre. Anthropologie et politique au XVII siècle, apud Hadi Rizk, op. cit. p. 170.

176 RIZK, Hadi, op. cit. p. 132. 


\section{5. O ESTADO E SUAS INSTITUIÇÕES}

Em capítulos precedentes está estampada a preocupação constante de Espinosa com a liberdade humana, ainda que esta seja apenas uma liberdade relativa, única forma de o ser humano ser feliz, buscando sempre a sua autopreservação e procurando exercer plenamente a sua potência natural.

Também patente o pensamento de que só os homens mais sábios procuram se comportar racionalmente, refreando impulsos de paixões naturais por objetos alienantes e nocivos, consumindo ou usufruindo com parcimônia e frugalidade de bens que lhes são caros, porém escassos, ou nocivos por excesso.

Todavia, a maior parte do povo não é inteiramente livre, já que se deixa conduzir apenas pela imaginação, não conseguindo refrear seus impulsos por objetos que os dominam e os alienam totalmente, o que pode conduzir à beligerância e à má utilização de sua potência finita, já naturalmente limitada.

Vimos, também, que uma forma de evitar o desperdício de energia, de poupar vidas, e aumentar a eficácia dos poderes individuais, foi a associação dos seres humanos em comunidades cada vez mais complexas, aportando uma maior potência coletiva com essa conjugação de esforços e harmonização de interesses.

E teria assim surgido o Estado, inicialmente como uma mera agremiação sem quaisquer contratos e leis escritas, regulado pelos concelhos dos mais sábios, ou mais poderosos, ou até mais astutos, posteriormente já com a consagração de costumes tornados obrigatórios. Com o crescimento destas associações, houve naturalmente a necessidade de se criarem instituições e leis para regular a vida em sociedade, eleger governantes e até órgãos especializados em segurança, tanto interna quanto externa.

Teriam surgido, assim, duas formas de organização política: uma dita civil, com instituições civis, tais como as cidades estados gregas, ou a civilização romana, ainda que essas civilizações fossem ciosas de seus cultos a seus deuses particulares e com suas instituições e direito impregnados de magia divina; outra, a que Espinosa chamou de "ordem profética", submetida totalmente aos ditames das religiões preconizada pelos Profetas. Esta "ordem profética", de que já tratamos no capítulo referente ao regime teocrático, procurava submeter o povo a cânones e rituais sagrados, tolhendo por completo a liberdade de pensamento e opinião, e poderia muito bem sobreviver sem leis escritas e sem o arcabouço das instituições políticas.

Apesar de Espinosa ter vivido num período especialmente conturbado pela guerra entre várias facções religiosas, disfrutava excepcionalmente em seu país, hoje 
Holanda, de uma relativa liberdade de pensamento. Ele sempre pensou que a Igreja, professasse ela qualquer credo, deveria ser despida de todo o poder político, temporal, e se devotar exclusivamente ao auxílio e conforto espirituais.

Em certos Estados da antiguidade nós deparamos com uma mescla entre esta "ordem profética" e a organização civil: são certos regimes totalitários, em que reis, faraós ou imperadores se investem da autoridade divina, como se fossem a própria encarnação dos deuses, e governam ditatorialmente, sem leis ou com um número reduzido delas, e cercados por um aparato de segurança para impor a estabilidade e a perpetuação no poder, baseados sempre na servilidade de um povo ignorante, imerso num mundo de medo e esperança.

$\mathrm{Na}$ Idade Moderna surgiram três obras que tentaram explicar ou legitimar os vários regimes políticos, e dar-Ihes sustentação ou estabilidade: "O Príncipe" de Maquiavel, "Do Direito da Guerra e Paz" de Grotius, e "Leviatã" de Hobbes.

Como afirma Roger Scruton ${ }^{177}$, não seria um elogio de somenos importância dizer que os Tratados Políticos de Espinosa podem ser comparados a essas obrasprimas. Mas Antonio Negri ${ }^{178}$ vai muito além dessa singela opinião de Roger Scruton. Para ele, o Tratado Político de Espinosa pode ser considerado rigorosamente como a obra que funda o pensamento político moderno na Europa. $\mathrm{E}$ isso porque, quanto à antiguidade grega, o pensamento espinosiano tem a vantagem da universalidade, não ficando restrito à polis e aos cidadãos livres; quanto aos pensadores políticos de seu tempo, e até muitos que the foram posteriores, em vez de seguir a linha hegemônica do trespasse da soberania e da alienação do direito natural, Espinosa logrou conservar a soberania e o direito natural nas mãos do povo. Espinosa não imaginaria possível a igualdade no direito e a desigualdade no poder instauradas nas modernas sociedades de massa, pela singela razão de que, para ele, direito era igual a poder.

Grotius defendia a lei natural como o fundamento da soberania dos Estados, mas essa lei natural não seria o direito natural dos indivíduos, e sim um conjunto de normas expressas de natureza contratual. Dentro de cada Estado, tudo seria permitido, exceto o que estivesse em desacordo com normas ou costumes de um

177 SCRUTON, Roger, op. cit. p. 101.

178 NEGRI, Antonio, op. cit. p. 37. 
Direito Internacional dos povos, derivando este o mais próximo possível da razão natural humana.

Segundo a sua concepção de Direito Internacional Público, os Estados seriam entidades soberanas, e dentro de seus territórios exerceriam com exclusividade e total legitimidade um poder incontrastável sobre seus súditos. Esse poder incontrastável sobre pessoas e bens dentro de seus espaços, só delimitado pelos reduzidos limites internacionalmente expressos, tinha uma vaga semelhança com o poder estatal absoluto de Hobbes.

A semelhança do pensamento político de Grotius e de Hobbes está na formação do Estado, e na implementação da sua soberania: a base, o fundamento jurídico e moral seria o hipotético "contrato social" elaborado pelos seres humanos, os quais renunciariam a seus direitos e delegá-los-iam ao soberano, em troca de paz e segurança.

Espinosa não concordava com esta teoria, como reiteradamente já visto neste trabalho, seja porque muitos direitos da pessoa são inalienáveis, intransferíveis (tal como o direito à vida, o direito à liberdade), seja porque esses pactos associativos seriam precários, suscetíveis de rompimento caso extrapolassem os limites de suas prerrogativas. Não seriam contratos duradouros, portanto, sacramentando um direito absoluto do soberano, tal como pretendia Hobbes.

A função da teoria política devia ser a formação de uma constituição, a qual conseguisse, simultaneamente, preservar a liberdade dos indivíduos, e tentar conciliar em toda a coletividade o exercício dos seus direitos naturais inalienáveis. Mas, como também já vimos, essa hipotética constituição teria de ser flexível ao extremo, baseada num consenso sempre renovado, de modo a permitir a acomodação de novos interesses sempre surgidos.

Tanto Hobbes quanto Grotius, ou mesmo Maquiavel, não se preocuparam, ou talvez não Ihes tenha ocorrido, traçar um esquema, ainda que embrionário, das várias instituições e poderes de que se revestiria o Estado para poder fazer valer essa hipotético pacto político, o contrato social.

Maquiavel preocupou-se tão somente em, sabiamente, prodigalizar inúmeros conselhos ao príncipe, de forma a granjear simpatia e erradicar sedições, 
podendo governar com justiça e assim trazer estabilidade. Por sua vez, Hobbes se dedicou a criar uma teoria da origem contratualista do Estado, e assim poder legitimar o uso do poder absoluto pelo soberano.

Já Espinosa, em seu curto Tratado Político, inacabado, já que prematuramente ceifada sua vida quando o elaborava, procurou delinear e especificar algumas instituições estatais, imprescindíveis à manutenção de um Estado mais duradouro, assente na busca da satisfação das necessidades do povo.

Assim, num Estado organizado racionalmente, sob o império de uma constituição flexível, a sujeição e a obediência dos seus súditos poderiam até prescindir das virtudes e das qualidades dos governantes. É o que Espinosa quer dizer quando comenta: "Para que um Estado dure, sua administração deve ser de tal modo organizada que não importe se seus governantes são conduzidos pela razão ou pelas paixões" 179 . Neste pequeno comentário, patente a constatação realista do filósofo, de que, embora os homens que as governem possam ser muitas vezes dominados pelas paixões e não pela razão, as instituições devem ser fortes o bastante para resistir a essa passagem.

Corroborando esta interpretação do pensamento espinosiano, Roger Scruton ${ }^{180}$ afirma que o poder deve ser outorgado não aos indivíduos, mas propriamente investido nos cargos que esses indivíduos ocupam, transformando esse cargo simultaneamente num poder conferido e num poder já limitado.

A finalidade da criação de um Estado deve ser a implantação, internamente, de uma ordem política e jurídica justa, legítima, que procure preservar a paz, a segurança, mas acima de tudo, o desenvolvimento pleno dos dotes e qualidades individuais dos cidadãos. E este objetivo seria mais facilmente atingido por meio de um pacto democrático, a ser realmente obedecido e cumprido, e assim poderse prescindir da voluntariedade e arbítrio dos governantes. Estes restringir-se-iam às suas funções já devidamente delimitadas, e não poderiam extrapolá-las. Um pacto deste tipo, se for realmente obedecido e cumprido, pode comportar qualquer regime, seja ela uma monarquia, uma aristocracia ou uma democracia.

\footnotetext{
179 ESPINOSA. TRATADO POLÍTICO, op. cit. p. 314.

180 SCRUTON, Roger, op. cit. p. 114.
} 
Assim, Espinosa ${ }^{181}$ comenta que a experiência costuma ensinar que, em determinadas condições históricas, na preservação da paz, da harmonia, da própria durabilidade dos regimes e permanência das leis, fosse até conveniente que todo o poder pertencesse a uma só pessoa. Mas, acrescenta, se a paz e a tranquilidade têm de ter como pressuposto a servidão e a solidão humanas, então de nada serviriam essa paz e tranquilidade. Seria a servidão, e não a paz, o móbil do poder pertencer a um só. "Um Estado, em que a paz é efeito da inércia dos súditos conduzidos como um rebanho e formados unicamente na servidão, merece mais o nome de solidão que o de Estado"182.

De fato, o filósofo não desaprovava totalmente a monarquia, especialmente se esta se revestisse de um formato constitucional bastante flexível, estabelecido com a participação e o consenso dos cidadãos, numa forma dinâmica e constitutiva. É esta a posição de Negri ${ }^{183}$ que interpreta a "monarquia moderada" de Espinosa como aquela em que se estabelece uma relação segura entre o poder monárquico e a inalienabilidade dos direitos dos cidadãos, ou seja, entre o exercício do poder e o estabelecimento do consenso geral. Ora, como o mesmo autor sublinha, estas limitações ao poder monárquico certamente desestabilizam, ou até inviabilizam, o tradicional conceito de monarquia.

Mas, como visto anteriormente, e interpretando harmonicamente o pensamento político espinosiano, o filósofo deixa transparecer claramente sua preferência pelo regime democrático, e isto por duas razões fundamentais: além de sua arraigada convicção na inalienabilidade dos poderes e direitos de cada um, na democracia é que se pode realizar o máximo da potência coletiva, pois todos os cidadãos integram de fato e de direito o Estado. E, deste modo, todas as potências singulares encontram-se engajadas num propósito único e coletivo, a qual representa mais que a soma dos poderes individuais, pois o todo tem uma mais valia acrescentada à mera soma das partes.

Ao contrário, em regimes oligárquicos, tais como o monárquico e o aristocrático, a maior parte de cidadãos e suas potências individuais, ficaria alijada do poder, sem concorrer para o aumento da potência coletiva. Uma vez que não tomaram parte

\footnotetext{
181 ESPINOSA. TRATADO POLITICO, op. cit. p. 330.

182 Ibid., p. 328.

${ }^{183}$ NEGRI, Antonio, op. cit. p. 48.
} 
nas decisões, não contribuiriam voluntariamente com seus esforços para a preservação do Estado. Só obedeceriam temporariamente, enquanto a razão não afastasse deles o medo irracional de um poder a eles inferior, e não afastasse também esperanças mal fundadas numa piedade inexistente.

Por essa razão, é que todo o regime político, seja ele democrático ou ditatorial, procura cooptar e arregimentar seus cidadãos para o empreendimento de tarefas comuns e com vista à obtenção de resultados que lhe sejam úteis.

Continuando nossa interpretação harmônica de todo o pensamento político espinosiano, atrás já exposto, os donos do poder sabem que precisam dos esforços de todos, se quiserem lograr a sua permanência no poder, e apelam a toda a sorte de artifícios para manter a coesão. No caso dos regimes ditatoriais, o medo, a repressão, fará com que os cidadãos se rebelem para poder exercer sua potência natural que não estão conseguindo fazer, e assim realizar sua essência natural. Quanto aos regimes oligárquicos, há uma deficiência de potências adicionadas, e os cidadãos não reconhecem a vontade dos donos do poder como suas, não tendo o Estado forças para vingar. Já o regime democrático, tende a perdurar por mais tempo, justamente pelo fato de os desígnios do Estado coincidirem com a vontade coletiva. Neste regime, os cidadãos conservariam livres seus pensamento e opinião, embora submetendo suas ações e sua capacidade de agir ao controle das leis estabelecidas pela maioria.

Assim, na democracia é que estariam cristalizados os verdadeiros fundamentos da criação do Estado: acima mesmo da preservação da paz e segurança, tal como pretendido pelos contratualistas e jusnaturalistas, o fundamento principal seria a preservação da liberdade e dos direitos inalienáveis.

Em seu Tratado Político, Espinosa ${ }^{184}$ define já algumas características que seriam exclusivas do regime democrático: enquanto em regimes oligárquicos só os privilegiados detinham o poder executivo e legiferante, formando uma casta que se perpetuava no tempo, no democrático todos os cidadãos possuíam o direito de sufrágio e o de ascender às funções públicas; todos poderiam, sem armas, reivindicar seus direitos; todos os que morassem no país com ânimo definitivo (contemplação aqui, já, tanto do jus soli quanto do jus sanguini) poderiam pleitear ${ }^{184}$ ESPINOSA. TRATADO POLÍTICO, ob. cit. p. 371. 
a cidadania; e qualquer cidadão só poderia ser privado desses direitos quando condenado por um juiz natural.

E como se defenderia, como se poderia proteger essa democracia, já que é sempre um regime delicado e frágil, pela própria necessidade de conciliação dos vários antagonismos que the são inerentes, pela necessidade de harmonizar tantos interesses divergentes e opostos? Como diz Espinosa ${ }^{185}$, com um exército formado por cidadãos, de preferência a mercenários, pois estes procurariam estar sempre sujeitos a quem lhes abrisse mais a bolsa, ou lhes atribuísse mais benesses, e tudo fariam para a manutenção desse estado de coisas bélico, já que se tratava de seu único ofício e profissão.

$\mathrm{E}$ de onde viriam os recursos necessários à manutenção das instituições? Espinosa ${ }^{186}$, um tanto utopicamente, fala de isenção fiscal para toda a nação em tempos de paz. O Estado viveria a expensas de suas propriedades, pois tudo, campos produtivos, bosques, solo urbano e todas as demais propriedades seriam de domínio público, as quais poderiam ser alugadas a particulares. O Estado viveria unicamente dessas rendas, não penalizando os cidadãos com tributos escorchantes, parasitando seu suor e sangue. Pois, como reiteradamente já analisado, o Estado não é um fim em si mesmo (como também já visto, os fins são sempre uma ilusão), mas apenas um meio de preservar a sociedade.

Espinosa, segundo aqui um pouco o pensamento de Aristóteles, propugnava pela formação de vários conselhos para gerir a administração, mas em que houvesse, no entanto, a rotatividade de seus membros com frequência. Em várias passagens de seu Tratado Político, criteriosa e especificamente, trata do funcionamento dessas assembleias. Assim, Espinosa ${ }^{187}$ estipula que as principais funções dessas assembleias seriam, além de manter a Lei Fundamental do Estado, emitir opiniões e diretrizes sobre a condução dos negócios políticos, promulgar as leis e os decretos, vigiar a correta aplicação e execução das leis e toda a administração do Estado. Não seria permitido ao governante legislar sobre qualquer assunto importante sem antes ter submetido a deliberação ao conselho.

\footnotetext{
185 ESPINOSA, TRATADO POLÍTICO, op. cit. p. 340.

186 Ibid., p. 332.

187 Ibid., p. 333.
} 
Em seu Tratado Político, Espinosa188 discorre sobre os "quoruns" necessários à aprovação das leis, em que estipulava a exigência da presença da maioria absoluta, para deliberar sobre questões fundamentais do Estado; e o estabelecimento de regras sobre a frequência com que esses mesmos conselhos dever-se-iam reunir, a fim de que todos os funcionários prestassem contas de sua administração e nada ficasse ao livre arbítrio de quem quer que seja.

Em outro ponto da sua obra, Espinosa ${ }^{189}$ fala sobre a necessidade do rodízio, de substituição frequente dos membros dos conselhos, o que valeria também para os membros do Senado. $E$ isto porque seria necessário que conselheiros e senadores não fossem eleitos vitaliciamente, mas por três, quatro ou cinco anos no máximo, para que a maior parte dos cidadãos pudesse ascender a tal honra. Além disso, se os cargos fossem vitalícios, os seus titulares poderiam tomar liberdades abusivas e talvez se deixassem conquistar por sinecuras ou favores.

Também a diplomacia e as relações internacionais foram contempladas por Espinosa $^{190:}$

\footnotetext{
"Reconheço, aliás, que não é muito possível manter secretos os desígnios de semelhante Estado. Mas todos devem reconhecer comigo que mais vale que 0 inimigo conheça os desígnios honestos de um Estado do que permaneçam ocultos aos cidadãos os maus desígnios de um déspota. Os que podem tratar secretamente dos negócios do Estado têm-no inteiramente em seu poder e, em tempos de paz, estendem armadilhas aos cidadãos, como as estendem ao inimigo em tempo de guerra. Que o silêncio seja frequentemente útil ao Estado, ninguém o pode negar; mas ninguém provará também que o Estado não pode subsistir sem o segredo. Entregar a alguém sem reserva a coisa pública e preservar a liberdade é completamente impossível, e é loucura querer evitar um mal ligeiro para admitir um grande mal. O mote daqueles que ambicionam o poder absoluto foi sempre que é do interesse da cidade que os seus negócios sejam tratados secretamente, e outras sentenças do mesmo gênero. Quanto mais estas se cobrem com o pretexto da utilidade, mais perigosamente tendem a estabelecer a escravidão".
}

Estas considerações enaltecem a necessidade de uma completa transparência, e da ampla publicidade de que deveriam se revestir os atos políticos, tanto nas relações internacionais como nos meandros da política interna, para evitar que, nos recônditos bastidores do poder, se tramassem perseguições, vindictas, confiscos, tudo na calada da noite, à revelia e contra os cidadãos de bem. Todas as deliberações e decisões deveriam ser tomadas às claras, sem o escuso pretexto de segredo de Estado, pois a grande utilidade desse procedimento

188 ESPINOSA, TRATADO POLÍTICO, op. cit. p. 333.

189 Ibid., p. 341.

190 lbid., p. 346. 
compensaria em muito um pequeno prejuízo em relação à segurança do próprio Estado.

Espinosa, também, amargurado e sofrendo uma das maiores perseguições religiosas já vistas, defendia corajosamente a liberdade religiosa e de culto. $\mathrm{A}$ religião é uma questão de foro íntimo e só poderia desabrochar com autenticidade num Estado "em que o juízo de cada um é livre e desimpedido, onde cada homem pode cultuar Deus tal como sua consciência lhe dita, e onde a liberdade é considerada a mais límpida e preciosa das coisas", conforme citado por Roger Scruton ${ }^{191}$.

Quanto à administração da justiça, foi pródigo em longos e prudentes comentários. Registre-se, aqui, que a ênfase não foi posta na defesa da propriedade, dos bens e privilégios dos mais poderosos, na manutenção do "status quo" vigente, como dois séculos depois os liberais positivaram em seus códigos civis. A ênfase vai para os direitos naturais inalienáveis do indivíduo, tais como a vida e a liberdade de pensamento e opinião. E se em algum momento esses direitos naturais fossem denegados ou limitados, seria legítima a desobediência coletiva para o seu restabelecimento, porque liberdade e vida se combatem por exigência da própria natureza.

A propósito de Justiça e de Juízes, assim doutrina Espinosa ${ }^{192}$ :

\begin{abstract}
"Também é conhecido por todos que os juízes devem ser suficientemente numerosos para que os particulares não possam conquistar com presentes a maioria deles, que eles devem exprimir a sua opinião, não publicamente, mas pelo escrutínio secreto, e que lhes é devida uma remuneração por seu serviço. Porém, o costume é atribuirIhes uma remuneração anual, de onde resulta que não põem pressa alguma em terminar os processos e que frequentemente os debates nunca acabem. Além disso, quando o confisco dos bens pelo Estado serve para aumentar os recursos do soberano, não é o direito e a virtude que importam".
\end{abstract}

Sobre este parágrafo, três observações são importantes: a primeira, sobre a constante, reiterada, preocupação espinosiana com a necessidade de um número expressivo de membros em qualquer conselho ou assembleia, seja de conselheiros, seja de juízes, a fim de tornar pouco exequível ou dificultar a compra de favores ou benesses; a segunda, sobre a necessidade de as decisões judiciais colegiadas saírem de um escrutínio secreto, ou seja, a necessidade de

191 SCRUTON, Roger, op. cit. p. 115.

192 ESPINOSA. TRATADO POLÍTICO, op. cit. p. 343. 
que as decisões importantes sobre temas candentes revelarem-se sempre unas, não conflitantes, de modo a ser escamoteada do povo possíveis divergências internas, e a noção de como os preceitos jurídicos são fluidos, movediços, passíveis de várias interpretações; e terceira observação, a preocupação com a celeridade no trânsito dos processos, a rápida prestação da justiça, obrigando os juízes a ganharem pela produção e não por subsídios fixos.

No parágrafo quarenta e um de seu Tratado Político ${ }^{193}$, encontramos a também sempre presente preocupação de Espinosa com a dignidade humana, proibindo os juízes de usar a tortura para obter uma confissão. E no parágrafo vinte e seis do mesmo capítulo, constatamos a obrigatoriedade da existência de cortes de apelação, para examinar se as sentenças terão sido dadas em conformidade com as regras de direito e com total imparcialidade.

É a consagração, ainda nos albores do modernismo, e muito antes das reformas dos iluministas, do princípio da dualidade de instâncias. Se uma das partes, aquela que tiver sido prejudicada no processo, puder demonstrar que o juiz se deixou corromper pelo adversário, tinha qualquer relação de amizade ou fosse desafeto de alguma das partes, ou que, ainda, não tenham sido observadas as formalidades legais e as regras de direito aplicáveis, o caso deveria ser totalmente reapreciado por outro juiz.

Deveras importante também de frisar aqui, a preocupação espinosiana de retirar daqueles que detêm o poder executivo, o poder de interpretação das leis, como relatado por Roger Scruton ${ }^{194}$ :

"Aqueles que administram ou possuem a soberania sempre tentam cercar suas ações
ditatoriais de um aspecto de legalidade (specie iuris) e persuadir o povo de que agem
por bons motivos; eles têm muita facilidade de fazer isso quando são os únicos
intérpretes da lei" Somente com um judiciário inteiramente independente, não sujeito a pressões políticas ou econômicas, teríamos uma administração e uma interpretação das leis em completa segurança. E Espinosa, segundo o mesmo autor ${ }^{195}$ nos dá então um exemplo bíblico, ao comentar que a capacidade de prejudicar alguém era em parte limitada para os líderes hebreus, já que a interpretação das leis cabia

${ }^{193}$ ESPINOSA. TRATADO POLÍTICO, op. cit. p. 334

${ }^{194}$ SCRUTON, Roger, op. cit. p. 113.

195 Ibid., p. 114. 
exclusivamente aos levitas, os quais, por sua vez, não tinham qualquer participação na administração. Esposava-se aqui, já, um prenúncio, uma sugestão da teoria da separação dos poderes.

Não é outra a posição de Roger Scruton ${ }^{196}$, para quem as considerações de Espinosa, em favor da independência judicial, revelariam uma de suas maiores intuições de seu pensamento político e jurídico, e se mostrariam como uma antecipação da teoria de Montesquieu sobre a separação dos poderes.

Mas Antonio Negri vai muito além desta contribuição política. Para este autor ${ }^{197}$, além de Espinosa ser o fundador do pensamento político moderno, como já vimos antes neste trabalho, ele ultrapassou o próprio sentido da modernidade, foi além dela. De fato, pode-se encarar, desde o renascimento, modernidade como o poder de transformar o mundo. E para Hegel a concepção espinosiana do ser era por demais limitada e indeterminada, já que todo ente era encarado como um simples modo produzido pela substância, e com ela identificado. A potência desse ente particular, portanto, seria totalmente incapaz de efetuar qualquer transformação no mundo. Mas, Espinosa consegue demonstrar que a potência finita do ser humano, ainda que limitada, faz parte da potência infinita divina e pode, consequentemente, apropriar-se dela para transformar o mundo. Com efeito, Espinosa identifica na razão o poder de reflexão sobre a consciência da necessidade e, portanto, a liberdade, ou melhor dizendo, a libertação da indeterminação e da incapacidade de transformar o mundo, tal como queria Hegel. Pois, esta potência assim racionalizada para transformar as coisas, não exige necessariamente uma ignorância das leis físicas da natureza, antes depende exatamente do conhecimento dessas leis para delas se poder valer e apropriar.

Corroborando o pensamento deste autor, Gleizer ${ }^{198}$ afirma que "o conatus humano, portanto, não é apenas um princípio de auto-conservação, mas também de auto-expansão e realização de tudo o que está contido em sua essência

\footnotetext{
196 SCRUTON, Roger, op. cit. 114.

197 NEGRI, Antonio, op. cit. p. 108.

198 GLEIZER, M. Espinosa e a Afetividade Humana, apud Rafael Rodrigues Pereira. O Conatus de Spinoza:auto-consevação ou liberdade? IN: Cadernos Espinosanos XIX, p. 87. Disponível em: http://www.ffich.usp.br/df/espinosanos/26 html. Acesso em 05 nov. 2014.
} 
singular". Ou seja, o conatus humano, tendo a razão como seu constituinte necessário, desfruta de um poder de aprimoramento que o faz transformar as coisas.

Como salienta Negri ${ }^{199}$, a modernidade imaginada por Hegel não é capaz de justificar a democracia. Com efeito, a força coletiva do absoluto hegeliano, e o poder político que emana desse ente assim criado, esmagam a força de todas as singularidades, originando um conceito apenas formal de democracia, pois submetem as reais forças produtivas ao domínio das relações de produção.

Na verdade, diz o mesmo autor ${ }^{200}$, a concepção do sujeito-indivíduo, submetido a um processo transcendental externo e finalista, informa 0 conceito de modernidade desde Descartes, Hegel e Heidegger. A essa concepção, Espinosa contrapõe outra baseada no sujeito coletivo, no amor e na potência racional. É uma teoria que exclui qualquer finalismo, e produz um processo contínuo, e nunca acabado, da constituição do ser coletivo. É uma alternativa válida à concepção falsa de modernidade que, ainda hoje, se faz presente em muitos autores, tais como Habermas, o qual, segundo Negri, nunca logrou ir além de Hegel em sua submissão ao domínio do absoluto. Espinosa está muito além disso: ele perfaz uma relação sempre tensa e dinâmica entre potência individual e o reino do absoluto, entre a singularidade do indivíduo e o coletivo estabelecido consensualmente.

Assim, de acordo com Althusser 201 :

"A filosofia de Espinosa introduziu uma revolução teórica sem precedentes na história da filosofia, e, sem dúvida, a maior revelação filosófica de todos os tempos, a ponto de podermos ter Espinosa, do ponto de vista filosófico, pelo único ancestral direto de Marx."

E isto, segundo Negri202, porque Espinosa funda uma concepção inteiramente nova de praxis sem qualquer resquício de finalismo, porque trouxe a imanência dos efeitos conectados à própria causa, ou seja, a causa permanece em seus efeitos, e por isso toda estrutura de poder está condicionada aos efeitos materiais

\footnotetext{
199 NEGRI, Antonio, op. cit. p. 117.

200 lbid., p. 118 - 119.

201 ALTHUSSER, Louis. Lire le Capital, apud Antonio Negri, op. cit. p. 119.

202 NEGRI, Antonio, op. cit. p. 119.
} 
que perpetra, é parte deles, e jamais poderá ser considerada como um corpo estranho e exógeno e a eles superior e, portanto, imutável.

Num outro sentido, mas na mesma linha de raciocínio, Michael A. Rosenthal203 afirma que, apesar de Hegel negar que Espinosa tenha dado algum sentido a uma teoria da história, Pierre Macherey confirma que há, sim, uma verdadeira teoria não hegeliana da história nos escritos e no pensamento espinosanos. Embora essa teoria não corresponda à dialética idealista hegeliana, não poderia corresponder mesmo, pois ela é fundamentada nas mudanças materiais que provocam alterações concomitantes em sua inteligibilidade. E, por sua vez, Etienne Balibar, citado pelo mesmo autor ${ }^{204}$, afirma que o materialismo radical espinosano não é de molde a diminuir o peso e a importância da história, mas, ao contrário, o que ele faz é imprimir-Ihe um novo significado ao explicar os vários eventos históricos por suas reais causas: "A vontade divina deixa de agir em nós e passa a agir por meio de nós ao longo do curso da história em que, por intermédio da nossa compreensão, passamos a ser seus agentes".

Ou seja, nós é que somos os verdadeiros agentes da história e não a vontade divina, já que a instantaneidade divina atua nos seres particulares como seus efeitos, e estes mesmos efeitos, com intelecção dessa causalidade, tornam-se causas autênticas também.

Em síntese, Espinosa poder ser considerado como o principal precursor do pensamento político moderno, com base em sua defesa intransigente de um regime democrático que conserve intacta a soberania coletiva fundada na soma das autonomias individuais, sem qualquer alienação do poder. Além disso, ele antecipou, em larga medida, o pensamento de Montesquieu ao traçar um quadro, ainda que embrionário, das várias instituições necessárias à manutenção de um Estado verdadeiramente democrático. Por outro lado, todo o conceito de modernidade pós-hegeliano, no sentido corrente de poder de transformar 0 mundo, resta prejudicado com o pensamento de Espinosa. Pois, para este, transformar o mundo só terá importância se isso conferir aos cidadãos, além de uma justa igualdade de direitos, uma igualdade de poderes também.

${ }^{203}$ ROSENTHAL, Michael A. Espinoza e a filisofia da história. IN: HUENEMANN, Charlie. Interpretando Espinoza: ensaios críticos, op. cit. p. 146.

204 lbid., p. 146. 


\section{CONCLUSÃO}

É comum, hoje em dia, o raciocínio de que as ideias de direito e política do homem moderno tiveram origem numa raiz jusnaturalista ou contratualista. Espinosa tenta-nos ensinar que não foi esse o verdadeiro caminho da evolução do pensamento jurídico e político moderno, e fundamenta suas razões numa matriz metafísica mais profunda.

O homem, como modo finito de ser e dotado de uma potência finita e singular, tenta sempre se esforçar por manter a sua autopreservação e buscar o que é útil à sua existência. Num primeiro estágio da humanidade, tudo o que avistasse the pareceria seu, e nada o deteria a não ser o limite de suas próprias forças. Só a experiência do dia a dia e o cultivo da razão lhe ensinaria a melhor maneira de, concretamente, levar a bom termo o seu esforço de autopreservação, o conatus esse preservandi. A experiência e seu apelo racional, é que o conduziriam à necessidade de associação, com vista a multiplicar suas possibilidades de sobrevivência e realizar seu projeto de vida inerente à sua natureza.

Não haveria nesse primeiro estágio nenhuma noção do bem e do mal, do lícito e do ilícito, do justo e do injusto, nenhuma dessas ideias jazeriam latentes no inconsciente humano, implantadas por uma razão desconhecida. Estas noções foram só produzidas mais tarde pelas sociedades organizadas, com o objetivo de se preservarem e manterem o status quo vigente.

A experiência juntamente com a razão humana geraram os vários tipos de sociedade e regimes políticos, numa lenta e constante evolução, fundada nas necessidades correntes e concretas e nos meios disponíveis. E foram essa experiência e essa razão, num menor ou maior grau, que criaram também a liberdade humana, não a liberdade absoluta assente no livre arbítrio, que essa não existe, mas a liberdade do possível na praxis do cotidiano, a liberdade de pensamento, da ciência e da arte, únicas liberdades possíveis. 
Ao medo do sobrenatural, e ao deslumbramento ante os fenômenos da natureza, ao terror infligido pelo medo da morte e do castigo divino, o ser humano contrapôs a única liberdade possível: agir racionalmente, buscar em sua razão o modo de se adequar e sobreviver face às leis implacáveis da natureza, à consciência de sua necessária finitude e à necessidade de satisfazer seus impulsos de sobrevivência.

E, junto com o devir histórico, e a conservação em sua memória das reiteradas manobras de resistência e sobrevivência, o ser humano soube conquistar um espaço especial na natureza, ao qual antes não estava reservado.

De fato, a grande maravilha da marcha da humanidade foi a conquista de um espaço não planejado na arquitetura da natureza. Aqui, um tanto ao arrepio do pensamento de Espinosa, ousamos dizer que o ser humano soube criar um império dentro do império da natureza.

Pois, para Espinosa, tudo era comandado pelas leis da natureza, tudo obedeceria rigidamente a cânones preestabelecidos, originados, não da vontade ou intelecto divinos, mas de sua real necessidade. A liberdade só viria com o pleno desenvolvimento de cada ser, se este lograsse extrair de sua existência o projeto de vida imanente em sua essência. Mas, com base no fato de que a razão humana é constituinte necessário do conatus e se traduz num esforço contínuo de aprimoração, somos propensos a dizer que a criatura humana, por meio da razão, abriu um mundo não planejado e não previsível, o mundo racional do conhecimento e da arte: de fato, só somos livres quando criamos, porque só quando criamos nos tornamos verdadeiramente autônomos e senhores de nós mesmos.

A experiência da praxis cotidiana registrada em sua memória, juntamente com o poder criativo da razão, conduziu os seres humanos rumo à única liberdade possível. O ser humano, por meio dessa razão e criatividade, conseguiu ser a causa adequada de um sem número de efeitos inéditos na natureza, o que the trouxe um mínimo de liberdade e livre arbítrio.

Mas a grande contribuição de Espinosa para a história do Direito e da Política, continua sendo sua crença inabalável no poder da razão humana como fator de 
liberdade, embora, como vimos, para ele essa liberdade estivesse limitada ao pleno desenvolvimento de um projeto imanente na essência de cada indivíduo.

Observamos, porém, que o exercício da razão humana, que é um dos componentes essenciais de sua potência natural, fez possível a liberdade de pensamento, fazendo surgir a arte e a ciência, criando aquele espaço livre de atuação, um universo livre dentro do universo necessário e real.

E é nesse espaço livre que ao homem é dado criar e transformar o mundo. Sua potência natural, de alguma forma investe-se de uma parcela da potência eterna e infinita da natureza da qual ele é parte, e consegue criar um mundo não planejado e não previsto.

Este é o aparente mistério que não é um mistério verdadeiro: mistério aparente, se considerarmos que um ser finito e criado, dotado de uma potência finita condicionada às leis físicas da natureza, consegue revestir-se de uma potência ilimitada, para criar um universo racional, por meios das artes e do conhecimento; mas não é realmente mistério, já que essa potência finita e singular faz parte da potência infinita de Deus ou Natureza, e, como vimos anteriormente, causa e efeito, e efeito e causa, permanecem inseparáveis e se condicionam. E aqui concordamos inteiramente com aqueles autores que conferem a Espinosa um status de ultramoderno, já que, por meio do instrumental da razão, a transformação do mundo não tem um limite, mas se trata de uma constante a ser reinventada, e não há modernidade possível sem a igualdade de direitos plasmada na igualdade de poderes.

Assim, o direito e a política são frutos da experiência e da razão humana na praxis do devir histórico, e não têm raízes naturalistas nem contratualistas.

E o poder político não pode ser atribuído a ninguém, com base em qualquer origem contratualista ou exógena, de modo a conferir aos donos do poder direitos e poderes acima da potência natural e direitos dos cidadãos. O poder político tem de ser outorgado por meios democráticos, resguardados os direitos elementares da pessoa, pois, reiterando um pensamento de Espinosa antes mencionado, ninguém pode jamais transferir tão radicalmente seu poder e seus direitos a outrem, a ponto de deixar de ser um homem. 
Aqui, a essência do pensamento político de Espinosa: o cidadão é que dispõe de inteira liberdade de criar governos, leis e instituições, mas sem jamais poder alienar o que é inalienável por natureza, que é a sua potência natural que o acompanha e se traduz no esforço para conservar sua vida e liberdade. Não pode o indivíduo abdicar de sua potência e direito natural, porque seria sua morte, e a morte é o adversário contra o qual se luta desde o começo da existência. 


\section{BIBLIOGRAFIA}

ALLISON, H. Benedict de Spinoza: An Introduction. New Haven: Yale University Press, 1987.

ALTHUSSER, Louis. Lire le Capital. Paris: Maspero, 1965, vol. II.

BALIBAR, E. Spinoza et la politique. Paris: PUF, 1985.

BARRETO, Ana Claudia Gama. BILATE, Danilo. Spinoza e Nietzsche: Filósofos Contra a Tradição. Rio de Janeiro: Mauad Editora Ltda., 2011.

BITTAR, Eduardo C. B. Almeida, Guilherme Assis de. Curso de Filosofia de Direito. São Paulo: Editora Atlas. 5ª Ed., 2007.

BOBBIO, Norberto; BOVERO, Michelangelo. Sociedade e Estado na filosofia política moderna. São Paulo: Brasiliense, 1991.

O Positivismo Jurídico: Lições de filosofia do direito. Tradução Márcio Pugliesi et allii. São Paulo: Ícone, 1995.

BOVE, L. La stratégie du conatus. Paris: Vrin, 1996.

CALDAS, Camilo Onoda et ali. Manual de Metodologia do Direito: Estudo e Pesquisa. São Paulo: Quartier Latin, 2010.

CHAUÍ, Marilena de Souza. A nervura do real: imanência e liberdade em Espinosa. São Paulo: Companhia das Letras, 2006.

Política em Espinosa. São Paulo: Companhia das Letras, 2003.

CHAUÍ, Marilena. A posição do agente da liberdade na ética $V$. IN: Cadernos Espinosanos, XXII, p. 21. Disponível em: http://www.ffich.usp.br/df/espinosanos/26 html. Acesso em 05 nov. 2014.

COULANGES, Fustel de. La Cité Antique. Editora Martin Claret, 2004.

DURANT, Will. Espinosa. Rio de Janeiro: Editora Tecnoprint Ltda. 
ESPINOSA, Baruch de. Correspondência. São Paulo: Editora Victor Civita. Editora Abril S.A., $1^{\text {a }}$ Ed. 1973. . Ética. São Paulo: Editora Victor Civita. Editora Abril S.A., 1를. 1973. . Pensamentos Metafísicos. São Paulo: Editora Victor Civita, Editora Abril S.A., $1^{\underline{a}}$ Ed. 1973. - Tratado da Correção do Intelecto. São Paulo: Editora Victor Civita, Editora Abril S.A., $1^{\underline{a}}$ Ed. 1973. . Tratado Político. São Paulo: Editora Abril, 1ํㅡㄹ. 1973.

ESTRADA DIAZ, Juan Antonio. Deus nas Tradições Filosóficas. São Paulo: Ed. Paulus, 2003.

FONTANA, Dino F. História da Filosofia. 3를. Eão Paulo: Editora Saraiva, 1969. FOUCAULT, Michel. Microfísica do poder. Rio de Janeiro: Graal, 1996.

FRATESCHI, Yara. A física da política: Hobbes contra Aristóteles. Campinas: Ed. Unicamp, 2008.

GARRETT, Don (org.). Spinoza. Tradução de Cassiano Terra Rodrigues. Aparecida/SP: Idéias \& Letras, 2011.

GLEIZER. M. Espinosa e a Afetividade Humana. Rio de Janeiro: Jorge Zahar, 2005.

HUENEMANN, Charlie. Interpretando Espinoza: ensaios críticos. Tradução de Getúlio Schanoski Jr. São Paulo: Madras, 2010.

JAEGER, Werner. Paidéia. São Paulo: Martins Fontes, 1995.

MAQUIAVEL, Nicolau. O Príncipe. São Paulo: Jardim dos Livros Editora Ltda, 2007.

MASCARO, Alysson Leandro. Filosofia do Direito. São Paulo: Atlas, 2010. 
MATHERON, Alexandre. La problématique juridique de Grotius. In: Anthropologie et politique au XVII siècle. Paris: Vrin, 1986.

MONDOLFO, Rodolfo. O Pensamento Antigo. São Paulo: Editora Mestre Jou, 1971.

MOREIRA, Adriana Belmonte. Potência da Razão e Liberdade Humana: uma análise do prefácio, axiomas e das quatro primeiras proposições da parte $\mathrm{V}$ da Ética. IN: Cadernos Espinosanos XXII, pág. 141/142. Disponível em: http://www.ffich.usp.br/df/espinosanos/26 html. Acesso em 05 nov. 2014.

MORIN, Edgar. O Mundo Moderno e a Questão Judaica. Rio de Janeiro: Ed. Bertrand Brasil, 2007.

NEGRI, Antonio. Spinoza subversivo: Variaciones (in)actuales. Traducción de Raúl Sánchez Cedillo. Madrid: Ediciones Akal, S.A., 2000.

La anomalia salvaje. Ensayo sobre poder y potencia em Baruch Spinoza. Barcelona, Anthropos, 1993.

PEREIRA, Rafael Rodrigues. O Conatus de Spinoza:auto-consevação ou liberdade? IN: Cadernos Espinosanos XIX, p. 87. Disponível em: http://www.ffich.usp.br/df/espinosanos/26 html. Acesso em 05 nov. 2014.

RADBRUCH, Gustav. Filosofia do Direito. Coimbra: Armenio Amado, Editor Sucessor, 1997, 6ª d.

RAMOND, Charles. Vocabulário de Espinosa. 1를 Ed. São Paulo: Editora Martins Fontes, 2010.

RIZK, Hadi. Compreender Spinoza. 2ª Edição. Petrópolis: Vozes, 2010.

ROSENTHAL, Michael A. Espinoza e a filosofia da história. In: Interpretando Espinoza: ensaios críticos. Editado por Charlie Huenemann; tradução Getúlio Schanoski Jr. São Paulo: Madras, 2010.

SANTIAGO, Homero. ENTRE SERVIDÃO E LIBERDADE. IN: Cadernos Espinosanos $\quad \mathrm{XXVI}, \quad$ p. $14 . \quad$ Disponível em: http://www.ffich.usp.br/df/espinosanos/26 html .Acesso em 05 nov. 2014.

SCRUTON, Roger. Espinosa. São Paulo: Fundação Editora Unesp, 2000. 
Espinosa. São Paulo: Edições Loyola, 2001.

SOLON, Ari Marcelo. Direito e Tradição: o legado grego, romano e bíblico. Rio de Janeiro: Elsevier, 2009.

STRATHERN, Paul. Spinoza. Rio de Janeiro: Ed. Jorge Zahar, 2000.

STRAUSS, Leo. La Critique de la Religion Chez Spinoza . Paris: Les Editions du Cerf, 1996.

VILLEY, Michel. Filosofia do Direito. 2aㅡ. Ed. São Paulo: Livraria Martins Fontes, 2008.

ZWEIG, Arnold. O Pensamento Vivo de Spinoza. São Paulo: Livraria Martins Editora, 1967. 